Volune 64 NOVEMBER, 1954 Nunger 1

\title{
CAPITAL GAINS TAXATION OF THE FRUITS OF PERSONAL EFFORT: BEFORE AND UNDER THE 1954 CODE
}

\section{PETER MILLER广}

THE Internal Revenue Code of 1954 points up the paradox that the capital gains tax often applies to gains not from an investment of capital but from personal effort. ${ }^{1}$ The new Code, however, is merely the latest in a series of recent statutory amendments and court decisions which have made a fine art of converting personal service income into capital gain. The techniques of this art have become so numerous that it is now appropriate to survey them both for their practical value to the taxpayer ${ }^{2}$ and for their implications for the rationale of favored treatment of capital gains. This review will show that the opportunities for capital gains treatment are almost non-existent where the taxpayer has only a contractual right to perform

iMember of the New York Bar. The author is indebted to Martin A. Roeder, Esq., for his stimulating conversations as to Section V and to Eugene R. Anderson, Esq., for his assistance in research on Sections II and III.

1. The dichotomy of income from personal effort ("earned income") and income from capital investment ("unearned income") will be used throughout this article in preferenec to some economists' conception of capital as the "congealed" labor of a prior period. See 1 Works and Correspondence of David Ricardo 52 (Sraffa ed. 1951). The distinction between earned income and unearned income is largely one of degrce: at one end of the spectrum is the stock market profit of the passive investor; at the other is the wage claim of the unskilled laborer. But ordinarily neither element is found in such pure form: the investor's profit is often due in part to his study of the market; the employee's compensation may reflect a substantial "capital expenditure" for vocational or professional training. See U.S. Treas. Reg. 118, §39.23(a)-15(f) (1953). But see Coughlin v. Commissioner, 203 F.2d 307 (2d Cir. 1953), reversing, 18 T.C. 528 (1952) ; Hill v. Commissioner, 181 F.2d 906 (4th Cir. 1950), reversing, 13 T.C. 291 (1949) ; I.T. 4044, 1951-1 Cuss. Bus. 16.

2. The present inquiry is not concerned with cases involving only questions of fact, e.g., whether compensation for personal services has been disguised as part of the purchase price for a capital asset whose market value cannot easily be ascertained. See, e.g., Fred MacMurray, 21 T.C. 15 (1953) (Commissioner failed to prove any part of profit from sale of screenplay was additional compensation for seller's performance in film based on the screenplay); Irving R. Lewis, 19 T.C. SS7 (1953) (part of sales price of stock held to be salary owed by corporation to vendor) ; W. P. Irelton, 11 T.C.MI. 133 (1952) (Tax Court refused to find sale of stock in liquor stores a "subterfuge" compensation for seller-incorporators' influence and services in obtaining inventory) ; Commissioner v. Beamsley, 205 F.2d 743 (7th Cir. 1953), reversing, 18 T.C. $98 S$ (1952) (payments by corporation purportedly for surrender of its stock held not taxable at ordinary rates to seller's husband as compensation for his influence in obtaining business for the corporation). 
personal services as an employee or independent contractor; that they become substantial where the taxpayer performs his services as a sole proprietor or partner; and that they are maximized where the services are performed for a corporation in which he holds stock. ${ }^{3}$ The sequence of the following discussion reflects these increasing opportunities for tax saving:

PAge:

I. Legislative Intent $\ldots \ldots \ldots \ldots \ldots \ldots \ldots \ldots \ldots \ldots \ldots \ldots$

A. Personal Service Holding Companies .............. 3

B. Termination Distributions by Employee Trusts ........ 5

C. Restricted Stock Options .................. 6

D. Literary, Musical, and Artistic Creations .......... 8

E. Inventions, Patents, and Designs .............

$F$. Collapsible Corporations ................. 12

G. Commutation of Contingent Deferred Compensation ..... 13

H. Accounts and Notes Receivable for Services. Rendered.... 15

II. Contractual Rights ...................... 16

A. "Capital Asset" Requirement ................ 16

1. Services Already Performed ............... 16

2. Services Not Yet Performed ............... 18

B. "Sale or Exchange" Requirement ............... 19

C. Exclusive Agency Contracts ................... 23

III. Good WILL ............................ 25

A. Good Will in General ..................... 26

$B$. Trade Names and Slogans ................. 27

C. Covenants Not to Compete ................. 39

D. Professional Practices ................... 30

IV. Partnership Interests $\ldots \ldots \ldots \ldots \ldots \ldots \ldots \ldots \ldots \ldots . \ldots \ldots$

A. Payments other than for Unrealized Income ......... 34

B. Payments for Unrealized Income prior to the 1054 Codc.. 35

1. Tax Treatment of Selling Partner ............ 35

2. Tax Treatment of Buying Partner ........... 37

3. "Collapsible Partnerships" ............... 3S

C. Payments for Unrealized Income under the 1954 Codc... 39

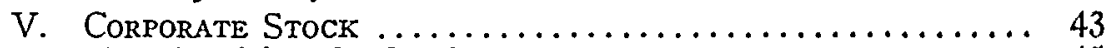

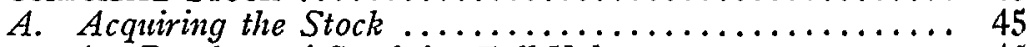

1. Purchase of Stock for Full Value .............. 46

2. Purchase of Stock for Less than Full Valuc........ 49

(a) "Restricted Stock Options" ........... 50

(b) Other Stock Options ................ 50

(c) Options to Resell ................... 52

(d) Restricted Stock .................. 54

(1) Taxable Compensation when Stock is Received ............... 55

(2) Taxable Compensation zohen Restrictions Lapse ........... 56

3. The normal activities of attorneys, brokers, investment bankers, and even politicians often afford them information not generally available to the public concerning speculative new ventures requiring only nominal investment and sometimes opportunities to buy stock not offered for sale to the public. Although the resultant capital gains are partly attributable to the individual's personal activities, they do not involve the conversion of potential compensation into capital gain except to the extent that he may perform "free" services for the corporation. 
(3) Taxable Compensation aihen Stock is Sold ................... 57

B. Preventing Attribution of Corporate Income to the Slock holder-Employee ...................... 58

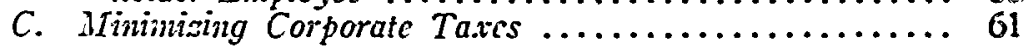

1. Surtax on Improperly Accumulated Surplus ....... 61

2. Excess Profits Tax ..................... 62

3. Corporate Income Tax .................. 63

(a) Mrultiple Corporations ............... 63

(b) Loss Corporations ................. of

(c) Collapsible Corporations: Distribution before Realization ..................... 65

(1) Tax Tratment of Stockholders... 65

(2) Tax Treatment of Corporation.... 71

(3) Distribution of Contingent Clains 73

D. Disposing of the Stock ........................... 75

1. Sales to Sister Corporations ................. 78

2. Sales of Preferred Stock Dizidends .............. 80

VI. Conclusion

LegISLAtIVE INTENT

The capital gains provisions of the Internal Revenue Code are of two main types. The general language of Sections 1201, 1202, 1221, and 1222 of the 1954 Code-Section 117 of the 1939 Code-provides long-term capital gain treatment of profit from the "sale or exchange" of "property" held for more than six months. ${ }^{4}$ The second type includes specific provisions dealing with certain narrowly-defined transactions. These specific provisions furnish the best available evidence of legislative intent, but they form no simple pattern: even while enlarging the opportunities for capital gains treatment of personal service income in some situations, Congress, in others, has stated that this is an improper use of the capital gains tax and has limited such opportunities.

\section{Personal Service Holding Companics}

Probably the earliest significant legislative action was the 1937 attempt to curb "incorporated talent" arrangements by amending the personal holding company provisions. Prior to this amendment, an executive or entertainer commanding high compensation frequently made his services available at a modest figure to a family corporation, which then contracted to furnish his services at their true value to third parties. ${ }^{5}$ The Ways and Means Committee objected to this scheme on the ground that the difference between the com-

4. INT. Rev. CODE of 1954, §1221 and INT. Rev. CODE OF 1939, §117(a) (1) exclude, among other things, stock in trade and real and depreciable property used in business from the category of "property" qualifying as a "capital asset."

5. Not until after 1937 did the courts threaten to upset arrangements of this type antedating the amendment. Compare Commissioner v. Laughton, 113 F.2d 103 (9th Cir. 1940), remanding, 40 B.T.A. 101 (1939), discussed in text at note 370 infra, writh Fontaine Fox, 37 B.T.A. 271 (1938). See also Jones v. Page, 102 F.2d 144 (5th Cir. 1938) (Bobby Jones, the golfer, taxed on compensation notwithstanding "sale" of his services for a numinal amount to his father, who assigned the compensation to a trust for Jones" children.) 
pensation received by the corporation and that paid to the performer was taxed at low corporate rates rather than graduated individual rates. ${ }^{\circ}$ It is obvious that this device produced no tax avoidance if, in order to cash in on the corporate accumulation, the taxpayer received dividends taxed at full individual rates. Hence, congressional condemnation of this scheme as a "loophole" seems due, at least in part, to the fact that it made possible a conversion of personal service income into capital gain by the performer-taxpayer's sale of stock or liquidation of the corporation. ${ }^{7}$

To plug this "loophole," Congress added income received by a corporation from "personal service contracts" to the category of "personal holding company income." 8 In most cases, ${ }^{0}$ this provision would subject the corporation to a confiscatory penalty surtax on undistributed earnings and would compel its earnings to be distributed-and taxed at graduated rates-to the stockholder. ${ }^{10}$ Combined corporate and personal taxes make it cheaper for the stockholder not to channel income from "personal service contracts" through a corporation.

Although its effect is drastic, the incorporated-talent amendment is so narrow in scope that it may not be an accurate barometer of legislative intent. By its terms, it is applicable only when either the contract or someone autside the corporation designates the individual who is to perform the services.11 Thus, if the customer will accept the services of any one of several men, the compensation of each can be accumulated by their corporate employer for later capital gains treatment. ${ }^{12}$ In view of its restricted operation, it is debat-

6. H.R. Rep. No. 1546, 75th Cong., 1st Sess. 5 (1937), 1939-1 CuM. Burl., pt. 2, 707.

7. Other factors would include: (a) the splitting of the taxpayer's earnings with relatives in lower brackets, (b) the postponement of the capital gains tax, giving the taxpayer the use of funds with no interest paid to the Government, and (c) the elimination of the capital gains tax if the sale or liquidation were delayed until after the taxpayer's death, at which time the basis of the stock in the hands of his estate or legatee would become its fair market value at the date of death or one year thereafter. INT. REV. CODE OF 1939, $\S 113(\mathfrak{a})$ (5) ; INT. REv. CODE OF 1954, § 1014.

8. "PERSONAL SERVICE CONTRACTS-(1) Amounts received under a con" tract under which the corporation is to furnish personal services; if some person other than the corporation has the right to designate (by name or by description) the individual who is to perform the services, or if the individual who is to perform the services is designated (by name or by description) in the contract; and (2) amounts received from the sale or other disposition of such a contract." Revenue Act of 1937, §353(e), 50 STAт. 814 (1937), corresponding to INT. REv. CODE OF 1939, $\$ 502$ (e) and INT. REv. CODE of 1954, $\$ 543$ (a) (5). However, such amounts are personal holding company income only if at least 25 percent of the corporate stock is held "directly or indirectly" by the performer.

9. To be a "personal holding company" subject to the surtax, more than fifty percent of the outstanding stock must be held by not more than five individuals and eighty percent of the corporation's gross income must consist of "personal holding company income." INT. REv. CODE OF 1939, § 502(a) ; INT. REv. CODE OF 1954, § 542(a).

10. The surtax is 75 percent on the first $\$ 2000$ of undistributed "personal holding company income" and 85 percent thereafter. INT. REv. CODE OF 1939, $\$ \S 500,504,505$; INT. REV. CODE OF 1954, $\$ \$ 541,545$. .

11. See note 8 supra.

12. Some of the difficulties encountered in accumulating income are discussed in text at notes $364-482$ infro. 
able whether the amendment reflects a broad congressional policy to subject all personal service earnings to the graduated income tax. But, at the very least, the amendment does imply that a combination of the regular corporate income tax at the time of earning and capital gains tax later is not alvays an acceptable substitute for the graduated personal tax.

\section{Termination Distributions by Employee Trusts}

If the 1937 personal holding company amendment does reflect a congressional policy against capital gain treatment of earnings from personal services, this policy underwent a sharp modification in the 1942 amendment to Section 165 (b).$^{13}$ This amendment provided that if in a single year by reason of severance of employment, an employee or his beneficiary receives from a qualified pension, profit-sharing, or stock-bonus trust, a final distribution in excess of his contributions to the trust, the excess is to be taxed as long-term capital gain. The Report of the Senate Finance Committee is not explicit as to its purpose, ${ }^{14}$ but the measure was undoubtedly adopted to mitigate the possible confiscatory effect of taxing the employee at ordinary rates in a single year on employer contributions and trust income accumulated over many years. Presumably capital gains treatment was preferred to the pro-rating relief of Section 10715 because it was more easily understandable by low-salaried employees with no ready access to tax advice. The limited scope of the 1942 amendment makes it again unlikely that much thought was given to broad implications. ${ }^{16}$

Assuming the propriety of capital gains treatment, it was anomalous for the 1942 amendment to grant it to lump-sum distributions by trusteed plans but not insured plans; or to beneficiaries of employees who die before retirement but not to those who die after retirement; or to an individual employee who leaves the company but not to all employees when the company ceases business and the plan terminates. Although the 1954 Code allows capital gains in all these cases, the Committee Reports are silent as to underlying policy. ${ }^{17}$ Section 165 (b) has raised itself by its own unrationalized bootstraps.

13. Revenue Act of 1942, § 162(a), 56 StAT. 862 (1942), corresponding to Istr. REv. CODE of 1939, \$165(b) and INT. REv. CODE OF 1954, §402(a) (2).

14. Ser. Rep. No. 1631, 77th Cong., 2d Sess. 138 (1942), 1942-2 Cuar. BuLL. 607.

15. INT. Rev. Code of 1939, § 107; INT. Rev. CODE of 1954, § 1301.

16. This portion of $\S 165$ (b) has been narrowly construed. Estate of Frank B. Fry, 19 T.C. 461 (1952), aff'd, 205 F.2d 517 (3d Cir. 1953); Edward Joseph Glinske, 17 T.C. 562 (1951) ; P. S. 61, P-H 1947 Fed. TAX SeRv. [ 76,237. But cf. MTary Miller, 22 T.C. No. 41 (1954).

Section 165(b) has been twice amended: in 1951 to permit the postpenement of capital gain tax on any part of the termination distribution representing appreciation in the value of securities of the employer corporation, Revenue Act of 1951, \$335(2), 65 SтAт. 507 (1951), and in 1952 to postpone the tax on appreciated employer securities purchased with employee contributions, even when the distribution is not occasioned by termination of $\mathrm{cm}$ ployment, 66 StAT. 766 (1952).

17. INT. Rev. CODE of 1954, $\$ \$ 402$ (a) (2), 403(a) (2). Capital gains treatment of distributions occasioned by liquidation of an employer corporation is limited by $\S 402(c)$ to 


\section{Restricted Stock Options}

The "bootstrap" principle of statutory growth is also illustrated by the development of Section 130A. ${ }^{18}$ This provision treats an employee who exercises an option to purchase stock of his corporate employer the same as an investor who happens to buy stock at a bargain price: no tax is imposed until-and unless ${ }^{19}$-the stock is sold and then only at capital gains rates. ${ }^{20}$ Section 130A contains a number of "limiting" requirements." The most important of these is that the option price must be at least 85 percent of fair market value of the stock when the option is granted, ${ }^{22}$ a rule supposedly intended to limit capital gains treatment to "incentive" as distinguished from "compensatory" options. This rule presumes that the distinction between stimulus and reward is significant for capital gains purposes ${ }^{23}$ and that the test of taxability should be the size of the bargain "spread" on the date of the grant of the option rather than the date of its exercise. But even the incentive theory compensates personal services-future services-of the employee. Thus with Section 130A Congress broadened the capital gains tax to include at least some of the fruits of personal effort.

The legislative history of Section 130A affords no clue as to how Congress reconciled this extension of the capital gains provisions with previous statements as to their purposes. ${ }^{24}$ The Senate Finance Committee merely argued

trust distributions made during the calendar year 1954. The original House version of this provision was to have permanent effect and was much broader in scope--so broad that small corporations probably could have been dissolved and reincorporated every few years to withdraw the plan's funds as capital gain. See, e.g., H. R. 8300, 83d Cong., 2d Sess. $\$ 401$ (b) (2) (B) (1954) (hereinafter cited as "H.R. 8300 (House Bill)").

18. InT. Rev. Code of 1939, §130A, INT. Rev. CoDE OF 1954, § 421.

19. If the employee dies before selling the stock, its appreciation in value to the date of death escapes taxation by reason of INT. REv. CodE of 1939, §113(a) (5) ; INT. REv. CoDE of $1954, \S 1014$, except to the limited extent provided in INT. REv. CODE of 1939, $\$ 130$ A (b) and INT. REv. CoDE of 1.954, $\$ 421$ (b). As to the effect of death prior to exercise of the option, see INT. Rev. CoDE of 1954, \$\$ 421 (d) (6), 691 (c) (2) (B).

20. If the option price is between 85 and 95 percent of the value of the stock when the option is granted, part of the profit on resale may be taxed as ordinary income under INT. REv. CodE of 1939, §130A (b) and INT. REv. CodE of 1954, § 421(b). The entire profit is capital gain if the option price is at least 95 percent. Sen. Rep. No. 2375, 81st Cong., $2 \mathrm{~d}$ Sess. 60 (1950).

21. For example, the Senate Report asserts that the requirement that the cmployec hold the stock for six months insures that he "actually invests in the stock of the company for a considerable period." Id. at 60 . This requirement is largely illusory both because a sixmonth investment is not likely to provide much "incentive" and because the cmployee could not sell the stock for at least six months without forfeiting long-term capital gain treatment anyway.

22. INT. Rev. Code of 1939, $\S 130 \mathrm{~A}$ (d) (1) (A) ; INT. Rev. CODE of 1954, $\S 421$ (d) (1) (A).

23. For a criticism of this viewpoint, see Miller, The Treasury's Proposal to Tax Emzployees' Bargain Purchases, 56 YAle L.J. 706 (1947), and letter from Dean Erwin N. Griswold to the author, dated May 22, 1947, reproduced in 93 Conc. REc. A4323 (1947).

24. There is no comprehensive official statement of the purposes of the capital gain tax, but such scattered utterances as appear in the Committee Reports and Treasury publications 
that a graduated tax in the year of purchase might force the employee to sell some of the "incentive" stock to pay the tax. ${ }^{25}$ This may be a sound argument for deferring the tax until disposition of the stock or death of the employee, but it does not explain why the deferred tax should be a capital gains tax.

The rationale of "restricted" stock options becomes even more uncertain with the extension of capital gains treatment to "variable price options" in the 1954 Code. ${ }^{26}$ This provision makes it possible to set the option price by formula at 85 percent of fair market value of the stock on the date the option is exercised. ${ }^{27}$ The executive-optionholder thus can receive the maximum 15 percent bargain spread if the value of the stock drops after the option is granted."3 It is not easy to harmonize this amendment with the original "incentive" theory of Section $130 \mathrm{~A}$ since it preserves the tax benefit to the executive, not only where the stock declines despite his best efforts (as in a nationwide recession), but also where the decline is caused by his own lack of diligence.9 Furthermore, since the valuation problem can apparently be eliminated by an agreement that the option price shall be the "fair market value of the stock on the exercise date as finally determined for federal income tax purposes," the amendment no longer squares with the 1950 statement of the Senate Finance Committee that the 5 to 15 percent spread is intended to afford a margin for error in valuation. ${ }^{31}$

are collected in Federal Incoste Tax Treitarent of Capital Gains ano Losses (1951). See also Mriller, The 'Capital Asset' Concept: A Critique of Capital Gains Tasation, 59 Y of the Ways and Mieans Committee adrocating favored treatment for capital gains on the ground that " $[t]$ he sale of farms, mineral properties, and other capital assets is now seriously retarded by the fact that gains and profits earned over a series of years are ... taxed as a lump sum .... in the year in which the profit is realized. Miany such sales with their possible profit taking, and consequent increase in the tax revenue, have been blod:ed by this feature of the present law." H.R. REP. No. 350, 67th Cong., 1st Sess. 10-11 (1921).

25. Sen. Rep. No. 2375, 81st Cong., 2d Sess. 60 (1950). U.S. Treas. Reg. 118, $\$ 39.22$ (a) -1(c) (1953), would tax as ordinary income the excess of market value at the time of exercise over the option price. For the reception of this regulation in the courts, see test at notes 324,325 infra.

26. INT. REv. CODE of $1954, \S 421$ (d) (1) (A) (ii).

27. See H.R. REP. No. 1337, 83d Cong., 2d Sess. 46-7, A153-4 (1954); SEx. REP. No. 1622, 83d Cong., 2d Sess. 59, 61, 293-4 (1954).

28. Presumably the executive receiving a "variable price option" may also be given a conventional fixed-price "restricted stock option" which would be more favorable if the stod: value rises after the option date.

29. Still this theory is repeated in H.R. REP. No. 1337, 83d Cong., 2d Sess. 47 (1954), which recommends that favored treatment be denied to options exercisable over a period longer than 10 years: "This action was taken because options granted over a longer period of time are almost certain to benefit the employee even if there is no action on his part to increase the success of his employer."

30. This drafting device is analogous to "marital deduction" will clauses which leave to the surviving spouse "an amount equal to one-half of the adjusted gross estate as finally determined for federal estate tax purposes."

31. "Ordinarily when an option is used as an incentive device, the option price approximates the fair market value of the stock at the time the option is granted. However, many 


\section{Literary, Musical, and Artistic Creations}

A reconciliation of Section 130A with official statements as to the scope of the capital gains provisions is further complicated by the fact that the Revenue Act of 1950 which introduced Section 130A also amended the general definition of "capital assets" in Section 117 (a) (1) ${ }^{32}$ to exclude a literary, musical, or artistic composition, a copyright, or "similar property"3s held by a taxpayer "whose personal efforts created such property." 34 This amendment was designed to overrule administrative ${ }^{35}$ and judicial ${ }^{36}$ decisions that an "outright sale" of a manuscript by an "amateur" author qualified as the sale of a capital asset. ${ }^{37}$ The Committee Reports characterized this interpretation as a "loophole" because "the taxpayer receives long-term capital gain treatment on the product of his personal effort." 38 At first blush this statement shows congressional disfavor of capital gains on any products of personal effort-

stocks are not listed on exchanges and therefore the fair market value is difficult to determine. Hence, your committee's bill requires that to qualify as a 'restricted stock option' the option price at the time of issuance must be 85 percent or more of the fair market value of the stock." SEN. REP. No. 2375, 81st Cong., 2d Sess. 60 (1950).

32. Revenue Act of $1950, \S 210(a), 64$ Stat. 932 (1950), corresponding to INT. Rev. CODE of 1939, §117(a) (1) (C) and INT. REv. CoDE of 1954, §1221(3).

33. An example of "similar property" is "a radio program which has been created by the personal efforts of the taxpayer." H.R. REP. No. 2319, 81st Cong., 2d Sess. 92 (1950). The problems of Jack Benny and "Amos ' $n$ ' Andy" prior to this amendment are discussed by Mintz, Entertainers and the Capital Gains Tax, 4 TAx L. REv. 275 (1949).

34. Section 117 (a) (1) also denies capital gains treatment when such property is sold by any other person required to use the creator's cost basis, e.g., a donee or controlled corporation. Attempted avoidance of the statute by transferring the property to a corporation and then selling its stock may run afoul of $\S 117(\mathrm{~m})$, also added by the 1950 Act (now $\S 341$ of the 1954 Code), which applies ordinary income tax rates to gain realized upon the sale of stock of a "collapsible corporation."

35. The Bureau's ruling that the income-reputedly $\$ 1,000,000$-from the sale of "Crusade in Europe" was taxable at the 25 percent capital gain rate rather than graduated rates up to 77 percent appears to have saved General Eisenhower roughly $\$ 500,000$ in tax. N.Y. Times, June 2, 1948, p. 31, col. 5.

36. Apparently all the cases permitting capital gains treatment of the procceds of literary, musical, and artistic property (as distinguished from patents and inventions) were decided after the ruling for General Eisenhower discussed in note 35 supra: Herwig v. United States, 105 F. Supp. 384 (Ct. Cl. 1952) (sale of motion picture rights to "Forever Amber" by Kathleen Winsor) ; Richard W. TeLinde, 18 T.C. 91 (1952) (sale of copyright to medical treatise) ; St. George v. Reynolds, P-H 1953 Fed. TAX SERv. $\llbracket 72,370$ (D.C. Minn. 1952) (sale of book by non-professional writer). See generally Fulda, Copyright Assignments and the Capital Gains Tax, 58 YALE L.J. 245 (1949).

37. The statutory basis of such rulings was that the assignment of exclusive rights in the taxpayer's creation was a "sale" of "property" and that, because of the infrequency of the taxpayer's dealings of this type, such "property" was not excluded from the "capital asset" category as "property held by the taxpayer primarily for sale to customers in the ordinary course of his trade or business." INT. Rev. CoDE of 1939, $\$ 117$ (a) (1) (A). See Miller, The "Capital Asset" Concept: A Critique of Capital Gains Taxation, 59 YALE L.J. $837,851-60$ (1950).

38. H.R. Rep. No. 2319, 81st Cong., 2d Sess. 92 (1950) ; SEN. Rep. No. 2375, 81st Cong., $2 d$ Sess. 43 (1950). 
at least in the absence of a special statutory exception like that for "restricted stock options." Such an inference is refuted by the Committee Reports themselves in commenting on the statutory exclusion of "similar property" :

"The interest of a sole proprietor in such a business enterprise as a photographic studio is not 'similar property' even though the value of the business may be largely attributable to the personal efforts of the sole proprietor." 33

Possibly the "loophole" statement can be reconciled on the basis of the practical difficulty of separating the personal-effort element from the other intangibles sold as part of a going business. ${ }^{40}$

\section{Inventions, Patents, and Designs}

Congress' loophole-closing policy is also contradicted by its decision to allow capital gains treatment to sales of inventions and patents by the "occasional inventor." The Finance Committee refused to follow the House in denying such treatment explaining:

"The desirability of fostering the work of such inventors outweighs the small amount of additional revenue which miglit be obtained under the House bill, and therefore the words 'invention,' 'patent,' and 'design' have been eliminated from this section of the bill."'1

This is the only congressional pronouncement since the genesis of favored treatment for capital gains in 1921 which affirmatively states that such treatment should be given to the fruits of personal effort, not under some special provision such as that for "restricted stock options" but under the general language concerning the "sale or exchange" of "capital assets." 2 There had been numerous court decisions, especially in the Tax Court, construing this general language to permit capital gains on the sale of a patent by its inventor. .3 $^{3}$ But these opinions failed to distinguish between the profit made by an inventor, which is primarily compensation for his personal efforts, and the profit made on the sale of a patent acquired by an investment of capital. Furthermore, these decisions can be criticized for applying the statutory word "property" mechanically and ignoring the absence of any indication that Congress intended the capital gains tax to apply to the sale of an invention by its inventor."

By supplying evidence of legislative approval of capital gains for inventors, Congress implied a major shift in the underlying philosophy of capital gains taxation. ${ }^{45}$ Since 1942, when the minimum holding period was reduced from

39. H.R. REP. No. 2319, 81st Cong., 2d Sess. 92 (1950).

40. See text at note 181 infra.

41. Sen. ReP. No. 2375, 81st Cong., 2d Sess. 43 (1950).

42. INT. Rev. CoDE OF 1939, § 117(a) ; INT. REv. Cone of 1954, § 1221.

43. See cases collected in Miller, supra note 37, at 851-60.

44. See note 24 supra.

45. See Miller, supra note 24, at 1057-86, for a discussion of the theories advanced within and without Congress. 
eighteen months to six months, ${ }^{46}$ the statute has not harmonized with the theory that the purpose of capital gains treatment is to mitigate the impact of graduated rates on profits arising over several years. The six-month holding period was rationalized as sufficient to distinguish "spectulative" from "investment" profits. ${ }^{47}$ Somehow capital gains treatment is thought to be appropriate for the profit on a sale of an "investment," 48 even though it arose in less than a year. ${ }^{49}$ Although it is possible to "invest" in business intangibles such as patents, an amateur inventor's investment is usually minor in comparison to the value of his personal efforts. Accordingly, congressional approval of capital gains for inventors expands the rationale of the capital gain provisions beyond the encouraging of "investment." Unfortunately the new rationale of capital gains is not spelled out by the Committee Reports. The only clue lies in the Finance Committee's assertion of "the clesirability of fostering the work" of occasional inventors. This statement assumes that capital gains treatment should be used to encourage "desirable" types of personal effort, and that personal effort is "desirable" if it results in an invention, a patent, or a design but not if it results in a literary, musical, or artistic work, a copyright, or "similar property."

Even if these assumptions are accepted, their objectives cannot effectively be accomplished under the general language of the statute pertaining to the "sale or exchange" of "capital assets." The basic difficulty is the negative statutory definition of "capital assets" as everything within the broad sweep of the "word "property" except what is explicitly exclucled. For this reason the policy of fostering amateur invention was expressed, not by an affirmative statement in the statute, but by silence-by failing to mention patents along with copyrights as one of the exclusions from "property." Statutory clraftsmanship which describes the hole but not the doughnut does not lend itself to a precise outline of the scope of an intended tax incentive. ${ }^{\text {ng }}$ Furthermore,

46. Revenue Act of 1942, § 150(a) (1.), 56 Star. 843 (1942).

47. "It is believed that a holding period of 6 months will be a sufficient deterrent to the speculator as contrasted with the legitimate investor." SEN. REP. No. 1631, 77th Cong., $2 \mathrm{~d}$ Sess. 50 (1941).

48. The phrase "held for profit or investment" modified "capital assets" in Revente Act of 1921, $\$ 206$ (a) (6), 42 STat. 233 (1921), but was deleted by Revenue Act of 1924, §208 (a) (8), 43 STAT. 263 (1924), for the express purpose of extending capital gain treatment to profit on the sale of a personal residence and other "property held for the personal use or consumption of the taxpayer or his family." SEN. REP. No. 398, 68th Cong., 1st Sess. 22 (1.924).

49. See Miller, supra note 24 , at 1058-9.

50. For example, it is not clear whether capital gain treatment is available for unpatentable intangibles such as technical know-how and secret trade formulae. A secret process has been held to be "property" susceptible of having a March 1, 1913 value for purposes of INT. Rev. Code of 1939, $\$ 113$ (a) (14) (now Int. Rev. Code of 1954, \$ 1053). Geor'ge S. Mepham, 3 B.T.A. 549 (1925). Cf. Nelson v. Commissioner, 203 F.2d 1, 6 (6th Cir. 1953): "It is well established that secret processes may constitute property and be dealt with contractually as such." But even if such intangibles constitute "property," payment for them might not be the proceeds of a "sale or exchange" unless received in the sale of a busi- 
there was little reason to encourage the "sale or exchange" but not the licensing of inventions. And even if a transaction qualified as a "sale or exchange," the inventor's right to capital gains treatment depended on such fortuities as whether his prior inventions had been sold or licensed, $"$ and whether his sales, present and prior, were "to customers." "33 Obviously these technicalities did not provide rational criteria for determining who was the "occasional inventor" deserving to be encouraged by tax benefits. ${ }^{54}$

These technicalities are largely, but not entirely, Code which seeks "to provide a larger incentive to all inventors to contribute to the welfare of the nation." Section 1235 specifically authorizes long-term capital gains treatment of the consideration received for a "transfer" of the rights evidenced by a patent or patent application. The statute applies whether or not (a) the taxpayer is an amateur, ${ }^{57}$ (b) the invention is held for six months, or (c) the transaction would qualify as a "sale or exchange"-the consideration may be payable periodically during the transferee's use of the patent or may be "contingent on [its] productivity, use, or disposition." The amendment is significant in marking a retreat from the only congressional attempt to use the general language of the capital gains provisions to encourage personal effort.

ness, in which event the intangibles would probably be treated as part of good will, as in the Mephan case.

51. The authorities appear still to be in conflict on the distinction between a sale and a license. Compare Gregg v. Commissioner, 203 F.2d 954 (3d Cir. 1953) ; Eterpen Financiers Sociedad De Responsabilidad v. United States, 108 F. Supp. 100 (Ct. Cl. 1952); Mim. 6490, 1950-1 Cunr. Bulr. 9; and Rev. Rul. 54-409, 1954 INt. Rev. Bull. No. 39 at 10 (1954) with Kavanagh v. Evans, 188 F.2d 234 (6th Cir. 1951) ; Allen v. Werner, 190 F.2d 840 (5th Cir. 1951) ; Kronner v. United States, 110 F. Supp. 730 (Ct. Cl. 1953); and Edward C. Myers, 6 T.C. 258 (1946). See also Joseph A. Fields, 14 T.C. 1202 (1950), aff'd, 189 F.2d 950 (2d Cir. 1951). See Note, 63 HaRv. L. Rev. 853 (1950).

52. Compare Harvey v. Commissioner, 171 F.2d 952 (9th Cir. 1949), and Harold T. Avery, 47 B.T.A. 538 (1942), with Samuel Diescher, 36 B.T.A. 732, aff'd, 110 F.2d 90 (3d Cir. 1940) ; Edward C. Miyers, supra note 51; and Leo P. Curtin, 6 T.C.AL. 457 (1947).

53. William M. Kelly, 6 T.C.M. 646 (1947).

54. See Miller, The "Capital Asset" Concept: A Critigue of Capilal Gains Taxation, 59 Y ALE L.J. 837, 860 (1950).

55. SEN. REP. NO. 1622, 83d Cong., 2d Sess. 441 (1954), states that $\$ 1235$ is not intended to affect the operation of "existing law" in areas beyond its scope, c.g., the status of corporate inventors. See note 50 supra. The House version of $\$ 1235$ was to have been "exclusive" H.R. REP. No. 1337, 83d Cong., 2d Sess. A280 (1954).

56. Ibid.

57. INT. REv. CODE of 1954, $\S 1235$ (b) (1). The new provision also applies to noninventors who purchased an interest in a patent from the creator before the invention is reduced to practice. $I d$. $\$ 1235$ (b) (2). This is intended to extend capital gains treatment to "individuals who contribute financially toward the development of the invention." SEx. REP. No. 1622, 83d Cong., 2d Sess. 440 (1954).

58. INT. Rev. Code of 1954, § 1235(a) (2). According to SEN. REP. No. 1622, 83d Cong., 2d Sess. 439 (1954), the phrase is intended to cover "amounts which are measured by a fised percentage of the selling price of the patent article, or are based on units manufactured or sold, or any other method measured by profits, production, sale or use." 


\section{Collapsible Corporations}

Further evidence of congressional ambivalence toward the capital gains status of income from personal efforts is found in the half-way treatment of "collapsible corporations" in Section $117(\mathrm{~m})$, also a product of the Reventue Act of 1950.59 Single-venture or born-to-die corporations had long been used in a variety of situations in which the element of personal effort was not predominant. ${ }^{\circ 0}$ Undoubtedly it was their use by motion picture producers, writers, and actors to convert compensation into capital gain which first aroused public attention and legislative action. " The essence of the "collapsible corporation" scheme was the creation of a separate corporation to produce each film. After the film was produced but before the corporation received box-office income, the stockholders would dissolve the corporation and realize a long-term capital gain on the difference between their investment and the fair market value of the corporate property distributed to them-the film itself or contracts under which it was to be distributed. ${ }^{62}$ They would obtain a stepped-up basis for this property equal to its fair market value. This basis could then be amortized to offset box-office income and permit it to be received tax-free. ${ }^{00}$ The stockholders would thus substitute a capital gains tax for both the corporate income tax and the personal income tax on dividends. ${ }^{04}$

Sections $117(\mathrm{~m})$ limits this double tax avoidance to the avoidance of only one tax. If the corporate tax is escaped by a sale of stock or distribution of property (in liquidation or otherwise) before realization of income by the corporation, Section $117(\mathrm{~m})$ requires the stockholders to report their profit as ordinary income rather than long-term capital gain. But if the corporation has realized, and paid tax on, ${ }^{65}$ a "substantial" part of the income from its productive activities, Section $117(\mathrm{~m})$ is inapplicable and the stockholders may still enjoy long-term capital gains. ${ }^{66}$ In this respect Section $117(\mathrm{~m})$ is more lenient than the 1937 personal holding company amendment ${ }^{67}$ which denies

59. Revenue Act of 1950, §212(a), 64 Stat. 906 (1950). Int. Rev. Code of 1939, $\S 117$ (m) ; INT. REv. CODE OF 1954, §341.

60. H.R. Rep. No. 2319, 81st Cong., 2d Sess. 57 (1950), mentions their frequent use in the construction industry.

61. See President Truman's message to Congress. N.Y. Herald Tribune, Jan. 24, 1950, p. 14 , col. 3.

62. The statutory mechanics are outlined in Miller, Capital Gains Taxation under the Revenue Act of 1950, N.Y.U. 9TH INST. on FED. TAx. 675, 683-5 (1951).

63. The fair market value used in computing the gain (and the stepped-up basis) would be equal to the estimated income from the film. If the post-liquidation receipts by the stockholders exceeded this estimate, the excess was taxable as ordinary income. Lewin v. Westover. 53-2 U.S. Tax CaS. $f 9619$ (D.C. Cal. 1953). Cf. Osenbach v. Commissioner, 198 F.2d 235 (4th Cir. 1952) (post-liquidation income under INT. REv. CoDE of 1939, §112(b) (7), now INT. REv. CODE OF 1954, § 333).

64. Compare Herbert v. Riddell, 103 F. Supp. 369 (S.D. Cal. 1952), with Bittker \& Redlich, Corporate Liquidations and the Income Tax, 5 TAx L. Rev. 437-48 (1950).

65. See discussion of $\S 337$ of the 1954 Code in text at notes 453-5 infra.

66. But see text at notes $425-6$ infra.

67. See text at notes 5-12 supra. 
capital gain treatment to income from personal efforts even though the regular corporate income tax has already been levied on such income.

Inconsistencies within the single Revenue Act of 1950 evidence the piecemeal congressional approach to capital gains on personal efforts and the lack of a philosophy as to the purposes of capital gains taxation. Use of the corporate form to obtain capital gain treatment of personal service compensation was condemned in the case of "collapsible corporations" at the very same time that it was facilitated in the case of "restricted stock options"; capital gains treatment was denied to authors, musicians, and artists but approved for inventors.

\section{Commutation of Contingent Deferred Compensation}

Section $117(p),{ }^{68}$ enacted in 1951, also bears the earmarks of random tinkering. This section accorded long-term capital gains treatment to the amount received for the assignment or release by a former employee of his right to receive deferred compensation under a contract which measured such compensation by the employer's profits or receipts for at least five years after termination of employment. This special treatment was available only if the entire payment had been received within one tasable year, if the employment relationship had existed for at least twenty years, and if the rights to the future payments had been part of the terms of employment for at least twelve years. ${ }^{69}$

Although this section applied to only a few taxpayers, ${ }^{\mathbf{7 0}}$ and has been substantially repealed without explanation by the 1954 Code, ${ }^{71}$ its rationale deserves attention both because it allowed capital gains treatment of compensation received directly from the taxpayer's employer and because it typifies the legislative approach to capital gains during recent years. The Senate Finance Committee thought it "unduly harsh" to apply graduated rates to the commuted value of several years' income received in one year merely because "the employee may not wish to leave his retirement income dependent upon the operation

68. INT. Rev. CODE of $1939, \S 117$ (p), as added by Revenue Act of $1951, \S 329$ (a), 65 Stat. 452 (1951).

69. The Committee Reports are silent as to the purpose of the 12 and 20 year requirements; presumably they were intended to discourage the creation of new profit-sharing rights expressly for the capital gain upon release of such rights.

70. Shannon, Bill Put Through for L. B. Mfayer Sazed Mozic Maler 3 1/4 Million, New York Post, Jan. 15, 1952, pp. 2, 14.

71. Section 117 (p) of the 1939 Code was listed as corresponding to $\S 405$ of the 1954 Code in Cross Reference Table I of H.R. 8300 (House Bill), but neither $\$ 405$ nor any other reference to $\S 117(\mathrm{p})$ appeared in the text of the bill or the accompanying H.R. REp. No. 1337, 83d Cong., 2d Sess. (1954). SEN. REP. No. 1622, 83d Cong., 2d Sess. 115 (1954), states: 'Your committee agrees with the House's objective of removing this provision prospectively but took that action in such a way as not to affect individuals who prior 101954 entered into employment contracts relying on the application of this provision." (Emphasis supplied). As restored by the Senate in $\$ 1240$ of the 1954 Code, capital gains treatment remains available for contracts created prior to the cnactment dale of the Code, August 16, 1954. 
of the business subsequent to the severance of his connection with it."72 But, presumably, the employee would never have entered into this tunusual contract had he not been willing to take the risks involved in having his deferred compensation depend upon post-employment profits or receipts. He has enjoyed lower graduated rates during his active years, and at retirement has the opportunity to spread his remaining compensation over several years. ${ }^{73}$ Congress does not explain why he is entitled to further tax relief when his own act causes him to receive the entire balance in a single year. ${ }^{74}$

Assuming that some form of tax relief is appropriate for lump-sum settlements of deferred compensation, ${ }^{75}$ it seems more consistent to provide such relief through Section $107^{76}$ than by granting capital gains treatment. Section 107 apparently received no consideration from the Senate Finance Committee, ${ }^{77}$ while two arguments for capital gain treatment were presented to the Committee by the United States Chamber of Commerce. ${ }^{78}$ The first was that this type of lump-sum payment is analogous to a termination distribution made under Section 165(b) by a "qualified" pension, profit-sharing, or stock bontus trust upon severance of employment. The analogy is not apt, for Section 165 (b) is part of an elaborate system of tax benefits supplementing Social Security by encouraging private employee trusts which meet carefully prescribed standards for the prevention of discrimination in favor of high-salaried employees. ${ }^{79}$ The second argument for capital gains taxation under Section $117(\mathrm{p})$ began with the assumption that deferred compensation measured by post-employment profits or receipts is characteristic of cases involving "the

72. Sen. Rep. No. 781, 82d Cong., 1st Sess. 50 (1951). The "Old Folks at Home" connotations of the word "retirement" were not supported by the text of $\S 117(p)$ which merely required that the employment terminate.

73. The few decisions in this area leave little reason to doubt this result. See commentaries collected by Barrett, Current Developments in the Deferred Compensation Mystery, N.Y.U. 11tr INST. on FED. TAX. 133 n.1 (1953). This income-spreading was expressly permitted by $\S 401$ (c) of H.R. 8300 (House Bill). See H.R. REp. No. 1337, 83d Cong,, 2d Sess. 43 (1954). Section 401 (c) was eliminated by the Senate without explanation.

74. See Eisenstein, $A$ Case of Deferred Compensation, 4 TAX L. REv. 391 (1949).

75. To obtain a release of the employee's right to share in future profits or receipts, the employer might agree to pay the lump-sum in installments over several years, thus converting the arrangement into the garden variety of deferred compensation. Rearrangements of this type have been permitted by the courts under certain circumstances. See, e.g., Commissioner v. Oates, 207 F.2d 711 (7th Cir. 1953), affirming, 18 T.C. 570 (1952) ; Howard Veit, 8 T.C. 809 (1947), 8 T.C.M. 919 (1949).

76. INT. REv. CODE OF 1939, § 107; INT. REv. CODE OF 1954, § 1301.

77. See Sen. Rep. No. 781, 82d Cong., 1st Sess. 50 (1951).

78. Statement of Ellsworth C. Alvord, Chairman, Committee on Federal Finance, Chamber of Commerce of the United States, Hearings before Senate Committee on Finance on H.R. 4473, 81st Cong., 1st Sess. 1464, 1478 (1951).

79. INT. Rev. Code of 1939, $\$ 165$ (a) (3), (4), (5) ; INT. Rev. Code of 1954, $\$ \S 401$ (a) (3), (4), (5). Many of the administrative interpretations of these sections are summarized in Rev. Rul. 33, 1953-1 CuM. Bunc. 267, 275-87. Although the anti-discrimination requirements were relaxed by $\S 501$ (e) (3) of H.R. 8300 (House Bill), the Senate restored the provisions of prior law. See SEN. Rep. No. 1622, 83d Cong., 2d Sess. 53-4 (1954). 
exploitation of some particular devices, productions, ideas, or other property, for which the employee was largely responsible." 80 This argument then asserts that "no uncertainty would exist [concerning the employee's right to capital gains] if, for example, the employee's efforts gave him a property right in a particular patent which, upon termination of his employment, he sold to his employer."81 The principal fallacy is that Section $117(\mathrm{p})$ is not limited to cases in which the employee has left with his employer an "invention," "patent," or "design" created by him. 82 Furthermore, even "occasional inventors" often failed to obtain capital gains. ${ }^{83}$

Whatever their merits, the arguments in favor of Section $117(p)$ illustrate the tendency of capital gains provisions to spawn other capital gains provisions. ${ }^{84}$ This tendency is a natural consequence of the need to reason by analogy to unrationalized existing capital gains sections. Like Topsy, the statute has "just grow'd."

\section{Accounts and Notes Receivable for Scrices Rendered}

While special provisions of the 1954 Code broaden capital gains treatment of inventions, stock options, and termination distributions under "qualified" employee plans, the new Code excludes from the capital asset category "accounts or notes receivable acquired in the ordinary course of trade or business for services rendered or from the sale of" most non-capital assets. ${ }^{85}$ This exclusion is primarily intended to allow an ordinary loss where a taxpayer accrues the receivable as ordinary income and then sells it at a loss instead of holding it until payment by the obligor. ${ }^{80}$ But, of course, the amendment also precludes capital gains treatment of a profit on the sale of an account or note previously taken into income at a discounted value. In other respects, it seems merely to codify precedent which by analogy would deny capital gains on the sale of claims for compensation. ${ }^{87}$ Nevertheless, the enactment may signalize a new congressional policy to prevent income originating in personal services from qualifying as the "sale or exchange" of a "capital asset" under the general capital gains provisions. Other traces of this congressional

80. See statement cited note 78 sipra.

81. See statement cited note 78 supra.

82. If the "particular devices, productions, ideas or ather property" created by the taxpayer constituted "similar property" under INr. REv. CODE of 1939, $\$ 117$ (a) (1)(C), the consideration for them would be taxable as ordinary income. See text at note 33 supro.

83. See text at notes 51-4 supra.

84. Thus $\S 117(\mathrm{k})(2)$ of the 1939 Code, affording capital gain treatment to the "dispasal" of timber, was extended to coal by $\$ 325$ of the Revenue Act of 1951, 65 STAr. 452 (1951).

85. INT. REv. CODE of 1954, § 1221(4).

86. H.R. REP. No. 1337, 83d Cong., 2d Sess. 82, A273-4 (1954). Cf. Graham Mrill \& Elevator Co. v. Thomas, 152 F.2d 564 (5th Cir. 1945) ; Rockford Varnish Co., 9 T.C. 171 (1947) ; and similar cases criticized in Miller, The "Capital Assef" Concept: $A$ Critique of Capital Gains Taxation, 59 YaLe L.J. 837, 871-7 (1950).

87. See text at notes 94-101 infra. 
attitude are found in the provisions of the 1954 Code which restrict capital gains treatment of personal service receivables held by "collapsible partnerships "88 and collapsible corporations."89

\section{Contractual Rights}

Capital gains have been uniformly denied where the taxpayer sells a contractual right to compensation for personal services, whether the services have already been performed or are still to be performed. In the latter case, however, an exception has been made for exclusive agency contracts. The decisions lost by the taxpayer are important in marking the shoals which await one who veers from the well-charted capital gains channels clescribed in later sections of this discussion. Most of these decisions turn on the general language of Section 117 (a) concerning the "sale or exchange" of "capital assets," since Congress was silent as to the capital gains status of the fruits of personal effort prior to 1950, except for whatever inferences could be drawn from two narrow provisions. $^{90}$

\section{"Capital Asset" Requirement \\ Services Already Performed}

By excluding "accounts or notes receivable . . . for services rendered" from the "capital asset" category," the 1954 Code destroys any statutory basis for an argument that capital gains treatment is available, for example, to the cashbasis doctor who receives value for an assignment of his claim for fees due from patients. But because the new section is limited to receivables "acquired in the ordinary course of trade or business," it is still necessary to look to the court decisions to determine the status of rights to potential income arising in non-recurrent transactions. Moreover, "accounts receivable" may be construed not to include contingent claims.

The dearth of decisions on the capital asset status of personal service claims under the pre-1954 Section 117 is easy to explain. ${ }^{22}$ During the 'twenties and 'thirties the possibility of obtaining capital gains was tunlikely to occur to taxpayers because of the limited purposes stated for the original 1921 enactment. ${ }^{93}$ Furthermore, before the holding period was reduced to six months in 1942, the assignment of a compensation claim could not have quali-

88. See text at notes $244-72$ infra.

89. See text at notes $446-51$ and $456-61$ infra.

90. INT. REv. CODE OF 1939, §§ 165(b), 502(e).

91. INT. REv. CoDE of 1954, § 1221 (4).

92. The cases most nearly in point are those stemming from Helvering v. Smith, $90 \mathrm{~F} .2 \mathrm{~d}$ 590 (2d Cir. 1937), discussed in text at notes 216-20 infra. See also Bessie Lasky, 22 T.C. No. 3 (1954), where capital gains were denied to Jesse Lasky, on a lump-sum payment received from United Artists for the assignment of Lasky's claim against Warner Bros. for a percentage of the receipts from a motion picture conceived by Lasky and based on a story owned by him: "There was, in fact, only payment of the total accruals to Lasky through an intermediary." Id. at 16.

93. See note 24 supra. 
fied for favored treatment unless two years (later eighteen months) had elapsed between the time the claim arose and the assignment, a likely situation only in cases of deferred compensation. ${ }^{94}$ Still another explanation is found in the discharge-of-obligation doctrine developed in OId Colony Trust Co. and other early cases. ${ }^{95}$ These decisions treat a debtor as having received income assigned to his creditor in discharge of his debt. Presumably, then, an assignor could be taxed on compensation paid to his assignee when the assignment was made in consideration of new value given expressly for the assigned compensation. ${ }^{96}$ Finally, the assignment would probably run afoul of the Supreme Court's Eubank rule. ${ }^{97}$ Eubank, a life insurance agent, was taxed on "earned" but unpaid renewal commissions which he had assigned to a trust. Although the Horst-Eubank opinion ${ }^{28}$ holds that assigned income is taxable to the earner whether he assigns it before he earns it ${ }^{09}$ or afterwards, the case may also be significant for capital gains purposes because of the distinction drawn between an assignment of rights in income-producing property and an assignment of rights to income itself. ${ }^{100}$ This distinction may be

94. The two-year holding period of the Revenue Act of 1921, §206(a) (6), 42 STAx. 232 (1921), was in effect until shortened to 18 months by Revenue Act of 1938, $\$ 117$ (a) (2), (4), 52 Stat. 500-01 (1938).

95. Old Colony Trust Co. v. Commissioner, 279 U.S. 716 (1929) (employee held taxable for compensation paid directly to Government as income tax on his behalf); Douglas v. Willcuts, 296 U.S. 1 (1935) (husband held taxable on trust income paid directly to divoreed wife in discharge of his obligation of support) ; cf. Raybestos-1fanhattan, Inc v. United States, 296 U.S. 60 (1935) ; United States v. Joliet \& Chicago Ry. Co., 315 U.S. 44 (1942).

96. The assignor would probably be permitted to offset the taxable assigned income by a deduction to the extent of any discount given the assignee. See O.D. 1009, 5 Cuss. BurL. 81 (1921) where a bank officer was required to report compensation for his services as receiver and trustee of the bank's insolvent debtor, but was allowed a business expense deduction for compensation turned over to the bank under a prior agreement. See also I.T. 1685, II-1 CuM. Bunl. 72 (1923). But cf. Mlayes v. United States, 207 F.2d 326 (10th Cir. 1953), affirming, 106 F. Supp. 961 (E.D. Okla. 1952), and cases cited therein. See also W.B. Mayes, Jr., 21 T.C. 286 (1953).

97. Helvering v. Eubank, 311 U.S. 122 (1940).

98. The opinion in Helvering v. Horst, 311 U.S. 112 (1940), was intended to apply to Eubank, a companion case.

99. Lucas v. Earl, 281 U.S. 111 (1930), held a husband taxable upon the entire amount earned by him notwithstanding a prior agreement with his wife that half of all his subsequent earnings should belong to her. The Court reasoned:

"There is no doubt that the statute could tax salaries to those who earned them and provide that the tax could not be escaped by anticipatory arrangements and contracts however skilfully devised to prevent the salary when paid from vesting even for a second in the man who earned it. That seems to us the import of the statute before us and we think that no distinction can be taken according to the motives leading to the arrangement by which the fruits Id. at 114-5.

are attributed to a different tree from that on which they grew."

100. The distinction is exemplified by Blair v. Commissioner, 300 U.S. 5 (1937) (trust income not taxable to life tenant after assignment of his entire interest in trust). 
used to exclude rights to personal service income from the word "property" in the definition of "capital assets." But few cases are explicit on the point."101

\section{Services Not Yet Performed}

Not all payments for the assignments of rights under personal service contracts are for claims based on services performed. $A$ may pay $B$ for the right to perform $B$ 's contract with $C$. The question of capital gains for $B$ is not affected by the amended definition of "capital assets" in the 1954 Code becautse $B$ 's contractual rights neither have been "acquired in the ordinary course of trade or business" nor have they arisen from "services rendered."102 This amendment thus differs from analogous 1954 amendments relating to "collapsible partnerships" and "collapsible corporations," both of which employ language broad enough to preclude capital gains on contractual rights to compensation for services "to be rendered."103

Standing alone, the 1954 Code might suggest that $B$ 's rights qualify as "capital assets," but there is no indication that Congress intended to overrule the leading case of Thurlow E. McFall. ${ }^{104} \mathrm{McF}$ all contracted to serve for five years as superintendent of the Sparta Foundry Co. for $\$ 100$ per week plus $1 / 6$ of Sparta's annual profits. Two years later A. W. Clutter \& Co., an underwriting firm, purchased this contract for $\$ 175,000$ cash because the profit-sharing feature interfered with plans to raise additional capital for Sparta. Still later, Clutter released Sparta from the contract in return for a

101. This type of reasoning is employed in Rhodes v. Commissioner, 131 F.2d 50 (Gth Cir. 1942), affirming, 43 B.T.A. 780 (1.941), which invoked Horst-Eubank and similar decisions to deny capital gains to the proceeds from an assignment of a declared dividend unaccompanied by a sale of the stock. And it seems implicit in several cases involving the assignment for value of rights to income arising from personal effort. See General Artists Corporation, 17 T.C. 1517 (1952), aff'd, 205 F.2d 360 (2d Cir. 1953), cert. denicd, 346 U.S. 866 (1953), discussed in text at notes $136-42$ infra. Cf. Estate of Thomas F. Remington, ? T.C. 99 (1947).

Without disputing the desirability of this result, one may wonder whether it logically follows from the Earl-Blair-Eubank line of cases. In those cases the issue was the identity of the taxpayer; under $\S 117$ the issue is the character of the income-whether it is a type that should be taxed at lower rates. Another distinction is that the makers of the gratuitous assignments claimed that they never "realized" the assigned income, while the assignor for value would claim that he has accelerated the "realization" of income. The latter distinction is noted in G.C.M. 24849, 1946-1 Cum. BuLL. 66, involving the assignment of a short-lived in-oil payment right carved out of a depletable interest in oil and gas in place. This ruling, is confusing insofar as it intimates that the Earl and Horst-Eubank cases have no bearing upon an assignment for value, citing as authority for this view the Rhodes case, supra.

102. INT. Rev. CODE of $1954, \S 1221$ (4).

103. Id. $\$ \S 741,751$ (a) deny capital gains treatment to that part of a payment for a partnership interest which is allocable to "unrealized receivables," defined by $I d . \S 751$ (c) to include "to the extent not previously includible in income under the method of accounting used by the partnership, any rights (contractual or otherwise) to payment for ... services rendered, or to be rendered." A similar definition of "unrealized receivables" is found in Id. $\$ 341$ (b) (4) relating to "collapsible corporations." See text at notes $448-9$ infra.

104. 34 B.T.A. 108 (1936). 
large block of Sparta's stock. ${ }^{105}$ The Board of Tax Appeals held that the $\$ 175,000$ was not capital gain to McFall for four overlapping reasons: (1) Before he had any contractual rights which he could sell, MIcFall was "obligated to perform services for the company."100 (2) Even if these rights were "property," they were not "capital."107 (3) Although the contract had been in existence for more than two years (the holding period then in effect), $\mathrm{McFall}$ 's rights under it were "not the sort of property which is susceptible of ownership for a length of time as is a share of stock, a bond, or a thing."10s (4) "The purpose of the statute, whether it be liberal or strict, is not served by including within it the contractual expectation of receiving pay for services not yet performed."109 Subsequent decisions apparently accept all four of these reasons, but stress the first, that the contract itself was not transferable property: "[the taxpayer's] qualifications and skill formed the material ingredient in the contract and such a contract cannot be sold."110

\section{"Sale or Exchange" Requircment}

Even if it is a "capital asset," a right to income under a personal service contract may not give rise to capital gains because the taxpayer has failed to make a "sale or exchange." The term "sale" usually means a transfer of property for cash or the transferee's promise to pay cash.111 An "exchange" is essentially a barter, differing from a "sale" in that the consideration received

105. Although McFall had no claim against Sparta for back pay, the amount received from Clutter can be viewed as the delayed product of MCFall's personal efforts-not his work under the profit-sharing contract, but his previous work which induced Sparta to share its profits with him.

106. Thurlow E. McFall, 34 B.T.A. 108, 110 (1936). Certainly it was not intended that McFall continue to work under the contract with his compensation paid to Clutter. It is equally clear that Clutter was not to perform MfcFall's services during the unexpired term of the contract. Had this been the plan, the Commissioner still could have argued that because a substitution would require the consent of Sparta, the transaction was not a "sale" but a novation whereby McFall's contract was cancelled and a new one made with Clutter.

107. Id. at 110. By this the Board may have meant that, when used in the definition of "capital assets," the word "property" connotes a substantial investment of capital by the taxpayer-a factor absent in MIcFall's case. It is arguable that the fact of little or no capital investment should affect the amount of the gain but not its character as "capital gain."

108. Thurlow E. McFall, 34 B.T.A. 108, 110 (1936). Cf. Richard S. Doyle, 37 B.T.A. 323,330 (1938).

109. Thurlow E. McFall, 34 B.T.A. 108, 110-11 (1936). The opinion does not cite congressional authority as to the purpose of the statute, but it presumably refers to the 1921 statement of the Ways and Means Committee, quoted in note 24 supra.

The Board also indicated its agreement with the Commissioner's alternate contention that what MicFall and his associate received was "the price to them of ending their contract, and not of selling it." Thurlow E. MIcFall, 34 B.T.A. 108, 111 (1936).

110. George K. Gann, 41 B.T.A. 388, 397 (1940) (capital gains treatment denied to payment received directly from taxpayer's employer for cancellation of unexpired term of employment contract).

111. See, e.g., Hale v. Helvering, 85 F.2d 819, 821 (D.C. Cir. 1936). 
by the transferor consists, at least in part, of property other than cash. ${ }^{112}$ Thus both "sale" and "exchange" ordinarily require a transfer by the taxpayer."11a

Because an individual who performs services is likely to receive reasonable value for his rights to compensation only from his employer, ${ }^{114}$ he rarely can obtain capital gain on these rights. An attempted "sale" of such rights to the employer runs into the general rule that where a right to receive payment is surrendered to the prospective payor, there is a satisfaction, modification or cancellation of the payee's right rather than the true assignment or transfer of the right necessary to a "sale or exchange."115 For example, in $W$. Morgan Shuster, ${ }^{116}$ this rule precluded capital gains treatment of an employer's payment to an employee for the cancellation of the unexpired term of his employment contract. Similarly, where the services have already been performed, cash payments by the taxpayer's employer have been treated as a satisfaction of the taxpayer's contractual claim for compensation in other forms than a

112. See, e.g., Trenton Cotton Oil Co. v. Commissioner, 147 F.2d 33, 36, rehcaring denied, 148 F.2d 208 (6th Cir. 1945) :

"'Exchange' is a word of precise import, meaning the giving of one thing for another, requiring the transfers to be in kind, and excluding transactions into which money enters either as the consideration or as a basis of measure."

Cf. Helvering v. Flaccus Oak Leather Co., 313 U.S. 247, 249 (1941). See also Gruver v. Commissioner, 142 F.2d 363, 365-6 (4th Cir. 1944):

"The criterion in determining whether a transaction is a sale or an exchange is whether there is a determination of the value of the things exchanged. If no price is set for either property, it is said to be an exchange; but if each is valued and the difference is paid in money, it is a sale."

113. But see Kessler v. United States, 124 F.2d 152, 154 (3d Cir. 1941) : ".... the verb 'exchange' is not restricted in meaning to the idea of an interchange but includes as well the thought of merely giving up something in consideration of the receipt of something else. Thus the plaintiff might have given up his partnership interest in exchange for the stock even though that interest as such did not pass to the corporation."

114. If the services have already been performed, a third party will rarely be willing to purchase the taxpayer's claim for compensation, although he may accept an assignment as security for a loan, retaining a right of recourse against the taxpayer. If the services have not yet been performed, the taxpayer's rights have little value even as security.

115. Hort v. Commissioner, 313 U.S. 28 (1941) (payment received by lessor from lessee for cancellation of lease); Helvering v. William Flaccus Oak Leather Co., 313 U.S. 247 (1941) (gain from proceeds of fire insurance); Fairbanks v. United States, 306 U.S. 436 (1939) (gain realized by bondholder upon redemption of bond before maturity) ; United Cigar-Whelan Stores Corp. v. District of Columbia, 176 F.2d 952 (D.C. Cir. 1949) (payment by lessor to lessee in cancellation of unexpired term of lease); Bingham v. Commissioner, 105 F.2d 971 (2d Cir. 1939) (loss on reconveyance of realty previously sold by taxpayer); Hale v. Helvering, 85 F.2d 819 (2d Cir. 1936) (settlement of a promissory note for less than face value); Charles E. McCartney, 12 T.C. 320 (1949) (payment for contract modification causing loss of profits to corporation partly owned by taxpayer); William G. H. Finch, 1 T.C.M. 191 (1942) (payment for cancellation of contract to furnish inventor with laboratory); Stewart E. Earle, 9 T.C.M. 1181 (1950) (mutual release of claims in controversy).

116. 42 B.T.A. 255 (1940), aff'd, 121 F.2d 643 (2d Cir. 1941). 
sum-certain of cash, rather than the proceeds of a "sale or exchange" of his claim. ${ }^{117}$

The "sale or exchange" requirement may also prevent the assignee of a claim from enjoying capital gains. In Marfin Charles Ansorge, ${ }^{118}$ a lawyer accepted as his fee an assignment of part of his client's claim in an expropriation suit. Ordinary rates were applied to his share of the recovery he obtained on the ground that he had made no "sale or exchange" of the claim but had merely collected it. And this reasoning was extended to deny capital gains treatment to the profit made by an attorney who paid cash for another attorney's share of a joint fee. ${ }^{119}$

Yet a broader interpretation of "sale or exchange" has evolved during recent years, apparently as a judicial reaction to the sweeping language of the Supreme Court in Hort $v$. Commissioner. ${ }^{120}$ In Hort capital gains were denied to a lessor who received a payment from his lessee for cancellation of the lease. But instead of stating simply that this was the extinguishment of a right rather than its "sale or exchange,"121 the Court reasoned:

"Where, as in this case, the disputed amount was essentially a substitute for rental payments which $\S 22$ (a) expressly characterizes as gross income, it must be regarded as ordinary income, and it is immaterial that for some purposes the contract creating the right to such payments may be treated as 'property' or 'capital'.

This may mean that capital gains treatment requires not only that there be a "sale or exchange" of a "capital asset" but also that the proceeds of the transaction do not take the place of ordinary income. 103

Since even the purest capital gain-the profit on the sale of stock-usually involves a commutation of anticipated dividend income, the lower courts

117. Matilda S. Puelicher, 6 T.C. 300 (1946) (compromise of promissory notes given as compensation) ; Joseph W. Frazer, 4 T.C. 1152 (1945), aff'd, 157 F.2d 282 (6th Cir. 1946), cert. denied, 329 U.S. 807 (1947) (payment to employee for surrender of interest in trusts for benefit of managerial employees); A.L. Parker, 5 T.C. 1355 (1945) (payment in compromise of contract for percentage of profits of hotels brought into hotel chain by taxpayer); Albert C. Becken, Jr., 5 T.C. 498 (1945) (cash payment in lieu of stock owed for services).

118. 1 T.C. 1160 (1943), aff'd, 147 F.2d 459 (2d Cir. 1945). See also Sloane v. Commissioner, 188 F.2d 254 (6th Cir. 1951), affirusing, Mferton E. Farr, 11 T.C. 552 (1948); Escher v. Commissioner, 78 F.2d 815 (3d Cir. 1935) ; Frank Hodous, 14 T.C. 1301 (1950).

119. Pat N. Fahey, 16 T.C. 105 (1951). See also Joseph A. Guthrie, 42 B.T.A. 696 (1940) (profit on interest in decedent's residuary estate purchased by taxpayer); Galvin Hudson, 20 T.C. 734 (1953) (profit on judgment claim purchased by taspayer); Green v. United States, 113 F. Supp. 295 (D. Neb. 1953).

120. Hort v. Commissioner, 313 U.S. 28 (1941), followed is Rev. Rul. 129, 1953 Irst. Rev. Bulz. No. 16, at 2 (1953).

121. This was the ground of the decision against the taxpayer by the Board of Tax Appeals. Walter M. Hort, 39 B.T.A. 922, 926 (1939).

122. Hort v, Commissioner, 313 U.S. 28 (1941).

123. So interpreted in dissenting opinion of Judge Frank in the MIcAllisfer case, infra note 125, and in Note, 56 YALE L.J. 570 (1947). See also Levin \& Mitosly, Tax Sozing Practices of Artists and Entertainers, 31 TAXEs 21, 25 (1953). 
have understandably attempted to limit the Court's language to the facts of the Hort case. They rarely invoke the Hort dictum where "sale or exchange" would ordinarily have been found under pre-Hort decisions, i.c., where the taxpayer assigns his rights to a third party, as distinguished from a transaction between the original parties. ${ }^{124}$ Other decisions construe Hort to turn on the fact that the right to future rentals did not survive as property in the hands of the lessee. They find a "sale or exchange" if what the payee gives up is property in the payor's hands, even where payor and payee are the original contracting parties. ${ }^{125}$ Still other cases imply that Hort is applicable only where the payment is a "substitute" for nothing more than ordinary income: it does not preclude a "sale or exchange" between the original parties to the contract, so long as the taxpayer parts with something more than a naked right to income. And this "something" need not survive as property in the hands of the payor. ${ }^{120}$

The conflict over whether there can be a "sale or exchange" of rights between original contracting parties is resolved by the 1954 Code in favor of

124. Hort was employed in cases involving transactions between the original partics in: F. W. Jessop, 16 T.C. 491 (1951) (capital gains denied to employee receiving lump-sum from his employer in consideration of cancellation of unexpired term of employment contract and employee's covenant not to compete) ; Elmer John LaPointe, 2 T.C.M. 252 (1943) (cash settlement of claim for wrongful discharge held ordinary income). However, in one case the Hort dictum has been invoked to deny capital gains treatment of a payment from a third party. Joseph Roscoe, P-H 1953 TC MEN. DEC. \$ 53,181 (1953), aff'd, 54-2 U.S. TAx CAS. If 9576 (5th Cir. 1954) (alternate holding that payment from purchaser of stock for cancellation of seller's exclusive brokerage contract with the corporation was a substitute for future commissions).

125. Commissioner v. Golonsky, 200 F.2d 72 (3d Cir. 1953), affirming, 16 T.C. 1450 (1951) (payment by lessor to lessee for surrender of possession and cancellation of unc:pired term of lease) ; Commissioner v. McCue Bros. \& Drummond, Inc., 210 F.2d 752 (2d Cir. 1954), affirming, 19 T.C. 667 (1953) (payment by lessor to lessee for surrender of possession under New York rent control laws).

See also McAllister v. Commissioner, 157 F.2d 235 (2d Cir. 1946) and Bell's Estate v. Commissioner, 137 F.2d 454 (8th Cir. 1943). In denying that payments made by trust remainderman for assignment of interest of income beneficiary were ordinary income because a substitute for future trust income, both majority opinions distinguished Hort on the ground that an income beneficiary's interest was "property" under the Blair case, supro note 100. The alternate theory of the Tax Court, that Hort applied because Mrs. McAllister "surrendered" rather than "sold" her interest, Beulah Eaton McAllister, 5 T.C. 714, 723 (1945), was also rejected by the Second Circuit, presumably because her interest was not founded upon a contract with the remainderman (which could be cancelled) but upon the will of the settlor. See Note, 53 CoL. L. REv. 976 (1953).

126. Jones v. Corbyn, 186 F.2d 450 (10th Cir. 1950) (payment by insurance company to insurance agent in cancellation of exclusive agency contract) ; Commissioner v. Ray, 210 F.2d 390 (5th Cir. 1954), affirming, 18 T.C. 438 (1952) (payment by lessor for lessee's consent to elimination of covenant prohibiting rental to lessee's competitors) ; Starr Brothers, Inc., 18 T.C. 149 (1952), rev'd, 204 F.2d 673 (2d Cir. 1953) (payment by manufacturer to retailer for cancellation of retailer's exclusive sales agency) ; Commissioner v. Goff, 212 F.2d 875 (3d Cir. 1954), affirming, 20 T.C. 561 (1953) (payment received from owner of machines for cancellation of payee's exclusive right to products of machines). 
capital gains on two types of contracts. Section 1241 provides that a "cancellation" of a lease or distributorship agreement is to be treated as an "exchange" by the lessee or distributor. However, the Senate Finance Committee Report is explicit that the amendment is not intended to affect personal service contracts, even by implication; ${ }^{127}$ accordingly, uncertainty may be expected to continue in that area. ${ }^{128}$

\section{Exclusive Agency Contracts}

Jones v. Corbyn ${ }^{129}$ is not only the principal personal service decision to depart from the traditional strict interpretation of "sale or exchange," but it also implies that the term "capital assets" includes a right to earn future personal service income in an exclusive capacity. The Corbyns were granted capital gains treatment on a $\$ 45,000$ payment received from a life insurance company in cancellation of their rights as the company's exclusive agent in Oklahoma. Since the settlement took into account the fact that the agents had previously earned $\$ 30,000$ a year under the agency contract, it represented, at least in part, the fruits of their prior services. The decision is based on the theory that there was a "sale and transfer of a going business." But all that the Corbyns gave up (apart from office space and records) was an exclusive right to earn commissions by writing policies in the future. They expressly reserved rights to renewal commissions already earned but payable in future years and apparently retained the right to use the firm's name and its subagencies to solicit insurance for other insurance companies. ${ }^{130}$ Accordingly, the Corbyn

127. "The section is limited in scope and it does not constitute a reevamination of present law relating to contracts to which the section does not specifically apply." SEx. REx. No. 1622, 83d Cong., 2d Sess. 115 (1954). "Since the section only applies to distributor's agreements in which the distributor has made a substantial capital investment in the distributorship, this section will not apply to cancellation of agreements requiring no substantial apital investment (as in Jones v. Corbyn, 186 F.2d 450) or to agreements that are not 'distributor's agreements' relating to goods as distinguished from intangible property." Id. at 444. The requirement of a substantial capital investment by the distributor but not by the lessee may indicate a desire not to facilitate the conversion of personal service income into capital gain.

128. Because of Jones v. Corbyn, 186 F.2d 450 (10th Cir. 1950), discussed in text at notes 129-34 infra, and the Second Circuit cases which declare its interpretation of "sale or exchange" unsound: Commissioner v. Starr Bros., Inc, 204 F.2d 673 (2d Cir. 1953), reversing, 18 T.C. 149 (1952); General Artists Corp. v. Commissioner, 205 F.2d 360 (2d Cir. 1953), affirnting, 17 T.C. 1717 (1952), cert. denied, 346 U.S. 866 (1953). But see Commissioner v. McCue Bros. \& Drummond, Inc, 210 F.2d 752, 753 (2d Cir. 1954), distinguishing Starr and General Artists on the ground that "the right of possession under a lease or otherwise, is a more substantial property right which does not lose its existence when it is transferred." A better distinction probably would be that the taxpayer's right to possession was derived from the New York rent control laws, so that no surrender of contractual rights was involved.

129. 186 F.2d 450 (10th Cir. 1950).

130. See dissenting opinion of Phillips, C.J.:

"Occidental did not acquire the right to use the name of the partnership, or to otherwise receive benefit from the good will built up by the partnership.... Occidental did not by virtue of the compromise agreement take over 
decision seems to mean that, although under the McFall rule ${ }^{131}$ the "mere" right to earn future compensation is not a "capital asset," it becomes a "capital asset" if it is an exclusive right. But if McFall had nothing to sell because his services were unique and he could not substitute someone to do his job, ${ }^{112}$ the Corbyns had little more since their agency contract could not be assigned without the principal's approval.133 Thus the court seems to have erred in stating that the contract "could be bought and sold."134

Although Corbyn was accepted by the Tax Court in Starr Brothers, Inc., ${ }^{100}$ it was later rejected by both Tax Court and Second Circuit in General Artists Corporation. ${ }^{136}$ GAC, a booking agency, had made contracts with Frank Sinatra to act as his exclusive agent. GAC was to receive ten percent of Sinatra's earnings from bookings it arranged, including earnings which might be received by Sinatra from such employment after expiration of the contracts. After performing booking services for Sinatra for part of the term of the contracts, GAC "sold" them to MCA Artists, Ltd. MCA agreed, with Sinatra's consent, to perform all of GAC's obligations, and the GAC contracts were cancelled and replaced by new contracts between MCA and Sinatra running well beyond the unexpired term of the GAC contracts. The "purchase price" of the GAC contracts was half the commissions to be received from Sinatra by MCA under both old and new contracts.

In rejecting GAC's contention that $\$ 39,000$ received from $\mathrm{MCA}$ in the first year was capital gain, the Tax Court and the Second Circuit agreed that $\$ 15,500$ of this amount, resulting from bookings arranged by $\mathrm{G} \Lambda \mathrm{C}$ before the "sale," was ordinary income to GAC under Eubank and other "assignment of income" cases. ${ }^{137}$ The balance, for which GAC performed no services, was said to represent the proceeds, not of a sale, but of the cancellation of the con-

a going business. It had to build or acquire a new agency and subagency personnel."

Jones v. Corbyn, 186 F.2d 450, 454-5 (10th Cir. 1950).

131. See text at notes $104-110$ sipra.

132. See George K. Gann, 41 B.T.A. 388 (1940), quoted in text at note 110 supra.

133. The agency contract was not "transferable without the consent of Occidental." See Jones v. Corbyn, 186 F.2d 450, 455 (10th Cir. 1950) (dissenting opinion).

The indistinguishability of Corbyn and McFall is stressed in Phillips' dissent.

134. Id. at 452. See 2 Williston, Contracts $\$ 421$ (rev. ed. 1936) : "No right to personal service under a bilateral contract can be assigned by either party to it."

135. 18 T.C. 149 (1952). Capital gains treatment was granted to a payment by United Drug Co. for cancellation of a retail drug store's exclusive right to market United's products in a city. In holding the exclusive contract a "capital asset," the Tax Court stressed the fact that the store received a dealer's mark-up rather than commissions, adding that "the agency contract did not require it to render personal services, though to be sure the petitioner expected to perform selling services in order to assure itself of income." Starr Brothers, Inc., 18 T.C. 149, 153 (1952). The Second Circuit reversed solely on the ground that the cancellation was not a "sale or exchange," assuming "arguendo" that the taxpayer's exclusive right was a capital asset. Commissioner v. Starr Bros., Inc., 204 F.2d 673 (2d Cir. 1953).

136. 17 T.C. 1517 (1952), aff'd, 205 F.2d 360 (2d Cir.), cert. denied, 346 U.S. 866 (1.953).

137. See text at notes $97-101$ supra. 
tracts. ${ }^{138}$ A majority of the Tax Court concurred in giving as additional reasons: The GAC contracts were not "salable property" under the MIF all rule because they called for GAC's personal services;"130 "[i]f one person, originally employed to do work, has another do the work, with the consent of the employer, for a part of the charge, the entire amount received is still ordinary income."140 Only five members of the Tax Court were of the view "that the interest of an agent in [an exclusive agency] contract is a property right or 'capital assets' subject to sale just as was the insurance agency in Jones v. Corbyn."141 Thus, there is now clear conflict of authority over whether an exclusive contractual right to earn income by performing services in the future is a "capital asset."142

\section{GOOD WILL}

Unlike the taxpayer who "sells" only a contractual right to earn income through personal services, the taxpayer whose efforts have produced good will ${ }^{143}$ and other intangibles, such as trade names and trade-marks, oiten ob-

138. The Second Circuit cited its own decision in Starr Bros. expressly disapproving the holding in Jones $v$. Corby"n that the cancellation of a contract could be a "sale or exchange." General Artists Corp. v. Commissioner, 205 F.2d 360, 361 (2d Cir. 1953). Neither the Tax Court nor the Second Circuit mentioned the fact that General Arlis/s differed from the usual canceliation case in that GAC dealt, not with the other party to the original contract (Sinatra), but with a third party (MCA). It can be argued that because an exclusive agency contract can be "sold" to a third party only with the consent of the principal, the transaction is not a "sale" but a novation whereby the old contract is extinguished and a new one created between the principal and the third party. See notes 106, 124, 134 supro.

139. Ordinarily a corporation is free to choose any fit person to periorm its contracts for "personal services," but the findings of fact indicate that at least one of GAC's contracts with Sinatra "provided that two persons named, and those only, should personally supervise Sinatra's business during the term of the contract but unnamed subagents employed by the agent might handle agency matters for Sinatra or assist the named persons." General Artists Corporation, 17 T.C. 1517, 1519 (1952).

140. Id. at 1523. The opinion cites Edwin J. MrcEnaney, 3 T.C. 552 (1944), in which a contractor was taxed on net commissions after deducting compensation paid for subcontractor's services. This proposition was thought inapplicable to GAC's case by the five dissenting Tax Court judges on the ground that GAC completely terminated its services for Sinatra and did not merely employ MCA to perform them as a subcontractor.

141. General Artists Corporation, 17 T.C. 1517, 1525 (1952).

142. See also Sammons v. Dunlap, P-H 1952 Fed. TAx SERv. q72,578 (D.C. Tex. 1952) (held, without citation of authorities, general agency contract with a health and accident insurance association is a "capital asset"); Charles J. Williams, 5 T.C. 639 (1945) (Tax Court refused to decide whether a general insurance agency was a "capital asset" but denied capital gains on other grounds). Cf. Camloc Fastener Corporation, 10 T.C. 1024 (1948) (damages paid for cancellation of exclusive agency contract held to be deductible business expense rather than capital investment).

143. Good will has been defined as the amount by which the capitalized earnings of a going business exceed the value of its tangible assets. George J. Stazb, 20 T.C. 834 (1953); A.R.M. 34, 2 Cuns. BULL. 31 (1920). Other definitions include only intangibles which cxist solely as part of the business (e.g., clientele) and cannot be sold separately. Pines, Fcderal Income Taxation of Intangible Assets, 8 TAx L. Rev. 231, 235 (1953). Although only the 
tains a capital gain on their sale. ${ }^{144}$ The capital asset status of trade intangibles is particularly important where they form part of an unincorporated oneman enterprise. A proprietary interest in a partnership or corporation can be sold as a single "capital asset." But, under the rule of Willians $v$. McGowan, ${ }^{145}$ a sole proprietorship is merely the aggregate of its component assets: machinery, inventory, fixtures, good will, and the like. Thus, when a one-man business is sold, the proceeds are allocated among its various assets, each of which must qualify separately for capital gains treatment. Where good will stems from the proprietor's efforts to build up a commercial reputation, the sales price allocated to good will is the fruition of these efforts.

\section{Good Will in General}

After giving scant attention to the matter until the late 1940 's, ${ }^{140}$ the courts have unanimously held that good will is a capital asset, regardless of the extent to which it reflects the activities of the owner of the business. ${ }^{147}$ The courts have not, however, indicated how the sale of good will is to be distinguished from the sale of a personal service contract. ${ }^{148}$ The inconsistency is illustrated by Elliot B. Smoak. ${ }^{140}$ Smoak contracted with the American Paper Bottle Co. to act as its exclusive representative in the East, his compensation to consist of part of the "royalties" from dairy companies using American's machines for packaging milk. He spent $\$ 26,000$ for an office, an advertising campaign, and an organization for marketing, installing, and repairing the machines. ${ }^{100}$ American subsequently combined its business with Ex-Cell-O Aircraft \& Tool Corporation, which had its own established agencies to market and service machines. Ex-Cell-O then induced Smoak to "sell" to it his rights under the

latter factors are mentioned in the classic definition of good will, STORY, PARTversurps $\$ 99$ (1881), adopted in Metropolitan Bank v. St. Louis Dispatch Co., 149 U.S. 436, 446 (1893), most tax decisions include all intangibles in good will. See, e.g., Union Metal Manufacturing Co., 1 B.T.A. 395, 397 (1925). See, generally, Note, 53 CoL. L. Rev. 660 (1953).

144. Though economically akin to good will and trade names, patents and copyrights receive special tax treatment. See text at notes $32-58$ supra.

145. 152 F.2d 570 (2d Cir. 1945), approved in Watson v. Commissioner, 345 U.S. 544, 552 (1953).

146. As late as 1947, a tax service could state: "No administrative or judicial interpretation of the status of good will as a capital asset is available ...." 2 CCH 1947 Fwn. TAX REP. IT 865.097 (1.947).

147. See cases cited notes 176, 177, 188 infra. Cf. Rainier Brewing Co., 7 T.C. 162 (1946), aff'd, 165 F.2d 217, rehearing dentied, 166 F.2d 324 (9th Cir. 1948) (trade name); Seattle Brewing \& Malting Co., 6 T.C. 856 (1946), aff'd per curiam, 165 F.2d 216, rehcaring devsied, 166 F.2d 326 (9th Cir. 1948) (same). For congressional support of this rule see quotation in text at note 39 supra.

148. Non-personal service contracts qualify as capital assets and thus need not be differentiated from good will, at least so far as the seller of the business is concerned. Sce Cowan, Tax Aspects of the Sale or Exchange of Contracts, 25 TAxes 31 (1947).

149. 43 B.T.A. 907 (1941).

150. The opinion does not indicate how much of the $\$ 26,000$ may have been deducted as current business expense. 
contract with American, including his right to royalties from future licensees within his territory, his right to future royalties from existing licensees, his office files and records, and the good will he had built up. The Board of Tax Appeals distinguished the McFall and Gamm cases, ${ }^{151}$ not on the ground that Smoak's right to earn future income was an exclusive right, but on the ground that Smoak gave up "much more" than this right-he sold a "going agency business."152 The Board held that such a business was a single "capital asset" and that Smoak's entire profit was capital gain.103

If the Smoak case had been decided after IWilliams v. MLCGouran, ${ }^{104}$ Smoak's profit would be allocated among the separate assets surrendered by him. Theoretically, capital gain treatment would be accorded to the portion attributable to good will, and ordinary rates would apply to the amount representing future royalties, not only for services already performed ${ }^{165}$ but also for services not yet performed. ${ }^{156}$ In practice, however, such allocation would be highly artificial because "good will" and "future royalties" are only different names for the discounted value of the same future income. ${ }^{107}$

\section{Trade Names and Slogans}

In Ellen J. Franklin, ${ }^{158}$ the capital gains treatment of good will was extended to cover compensation for the use of a trade name deriving its value from the taxpayer's personal efforts. Mrs. Franklin was widely known as a maker of womens' wearing apparel. To obtain capital, her wholly-owned corporation transferred several retail shops to a new corporation which issued part of its stock to the old corporation and part to other persons for cash. As payment for the use of her name, the new corporation, "MIrs. Franklin Shops of Philadelphia, Inc.," issued to Mrs. Franklin personally 200 shares of its stock and promised to pay her $\$ 75$ per week. In a prior decision the Tax Court had held these weekly payments nondeductible by the corporation on the theory that they represented the purchase price of good will, a capital asset. ${ }^{100}$ De-

151. See text at notes 104-110 supra.

152. Elliot B. Smoak, 43 B.T.A. 907,910 (1941). This characterization is debatable because, although technically an "independent contractor," Smoak apparently received all his commissions from American and did no "business" with anyone else.

153. Id. at 911. The Commissioner also argued that, even if Smoak's contractual rights constituted a capital asset, they had not been sold but cancelled. The Board refused to consider this argument-apparently because it construed the statutory notice of deficiency to raise only the capital asset issue. $I d$. at 909.

154. See text at note 145 supra.

155. See text at notes $92-101$ supra.

156. See text at notes 104-110 supra.

157. This allocation can perhaps be defended on the ground that Smoak gave up future income which would have been economically attributable partly to his contract with American ("future royalties") and partly to his contacts with the dairies ("good vill").

158. 6 T.C.M. 1099 (1947).

159. Mrs. Franklin Shops of Philadelphia, Inc., P-H 1947 T.C. AIEs. Drc. $\llbracket 44,135$ (1947). 
claring itself bound by this interpretation, the Tax Court held that the weekly payments were capital gains to Mrs. Franklin. ${ }^{160}$

The other cases which grant capital gains treatment to trade names and trade-marks as "property" 161 in the nature of good will $\mathbf{1 0 2}$ each involve a sale of the whole or part of a business. ${ }^{103}$ This reflects the rule of substantive law that trade names and trade-marks cannot be assigned or sold "in gross" but only as part of the business using the name or mark. ${ }^{104}$ Accordingly, had it not been for the transfer of the retail shops by her wholly-owned corporation, Mrs. Franklin might have been taxed at ordinary rates on the ground that she had merely licensed the trade name and not assigned it. ${ }^{105}$

In view of the important substantive differences between trade-marks and copyrights, ${ }^{166}$ it is doubtful that trade names and trade-marks are affected by the exclusions from the "capital asset" category of a "copyright," a "literary composition" or "similar property" created by the taxpayer's personal efforts. ${ }^{167}$ However, if part of the good will of a sole proprietorship consisted of a copyrighted trade-mark or trade name created by the proprietor, the Com-

160. Ellen J. Franklin, 6 T.C.M. 1099, 1100 (1947). No issue was raised as to the tax treatment of the 200 shares of stock, presumably because they were received prior to the year in controversy.

161. See Holmes, J. in Beech-Nut Co. v. P. Lorillard Co., 273 U.S. 629, 632 (1927): " $[I] \mathrm{n}$ a qualified sense the mark is property, protected and alienable, although as with other property its outline is shown only by the law of torts, of which the right is a prophetic summary." See also 52 AM. Jur. 513 (1944).

162. See J.S. Tyree, Chemist v. Thymo Borine Laboratory, 151 F.2d 621, 623 (7th Cir. 1945) : "The function of a trademark is to designate the goods as the product of a particular trader and to protect his good will against the sale of another's product as his." $C f$. Standard Brands v. Smidler, 151 F.2d 34 (2d Cir. 1945) ; E. F. Prichard Co. v. Consumers Brewing Co., 136 F.2d 512 (6th Cir. 1943).

163. Seattle Brewing \& Malting Co., note 147 supra; Rainier Brewing Co., note 147 supra. The element of personal effort may have been present in Semon Amzalals, 12 T.C.M. $\{19,970$ (1953) (family corporation realized capital gain from sale of store name).

164. Section 10 of the Lanham Act, 60 StaT. 431 (1946), 15 U.S.C. $\$ 1060$ (1953). American Broadcasting Co. v. Wahl, 121 F.2d 412, 413 (2d Cir. 1941): "A tradc-mark is intended to identify the goods of the owner and to safeguard his good will. The designation if employed by a person other than the one whose business it serves to identify would be misleading. Consequently ' $a$ right to the use of a trade-mark or trade name cannot be transferred in gross.' Restatement Torts $\$ 755$." Cf. Kidd v. Johnson, 100 U.S. 617, 620 (1879). It is only in unusual cases that a trade-mark may be transferred without the transfer of physical assets. See Continental Distilling Corp. v. Old Charter Distillery Co., 188 F.2d 614 (D.C. Cir. 1950).

165. See Thomas D. Armour, 22 T.C. No. 24 (1954). There a professional golfer was denied capital gains treatment on the ground that he had only licensed use of his name and photograph by sporting goods manufacturers.

166. Compare 60 StaT. 427 (1946), 15 U.S.C. $\$ \$ 1051$ et seq. (1953), zvith 61 STAT. 652 (1947), 17 U.S.C. $\$ \S 1$ et seq. (1953). See also United States v. Steffens, 100 U.S. 82 (1879), holding statute for the registration of trade-marks unconstitutional under the "Authors and Inventors Clause," U.S. ConsT. Art. I, § 8, cl. 8, but suggesting that such legislation would be permissible under the "Commerce Clause," Id., cl. 3.

167. Int. Rev. CoDe of 1939, §117(a) (1) (C) ; INT. Rev. Code of 1954, \$1221(3). There have been no judicial interpretations of these sections. 
missioner might seek to deny capital gains to a corresponding fraction of the sales price of the business. ${ }^{108}$ There is probably a greater risk that the "literary composition" and "similar property" exclusions will preclude capital gains on a sole proprietor's advertising ideas and slogans. ${ }^{163}$ And even if such intangibles should qualify as "property,"170 the taxpayer's activities might cause them to be excluded as "property held by the taxpayer primarily for sale to customers in the ordinary course of his trade or business."171 Finally, their disposition would have to be effected through a "sale or exchange" rather than a licensing arrangement. ${ }^{172}$ Because of these obstacles, capital gains on advertising intangibles are likely to be available, if at all, only where the intangibles can be treated as an integral part of good will upon the sale of a going business. ${ }^{173}$

\section{Covenants Not to Compete}

Because a sale of good will is often accompanied by the seller's covenant not to compete with the purchaser, and because a covenant not to solicit old customers will be implied in most states on any sale of a business, ${ }^{174}$ the recent arrival of good will as a capital asset has forced the courts to distinguish earlier decisions holding that payment received for a covenant not to compete is ordinary income. ${ }^{175}$ This problem and its judicial "solution" are illustrated

168. If good will is not to be excluded from the capital asset category as "similar property" (see text at note 39 supra), it seems artificial to exclude good will merely because copyrighted.

169. These intangibles may be more closely analogous to a radio program (see note $\mathbf{3 3}$ supra), than to the good will of a photographic studio (see text at note 39 stopra).

170. Compare Belt v. Hamilton National Bank, 108 F. Supp. 699 (D.C. Col. 1952), with Golding v. R.K.O. Pictures, 35 Cal.2d 690, 221 P.2d 95 (1950) ; Meyer v. Liggett \& Myers Tobacco Co., 101 Ind. App. 420, 194 N.E. 206 (1935) ; Lars Co. v. Nicol, 224 Minn. 1, 28 N.W.2d 705 (1946); and Ryan v. Century Brewing Assn., 185 Wash. 600, 55 P.2d 1053 (1936). Advertising ideas are sometimes protected without deciding whether they constitute "property." Matarese v. Moore-McCormack, 158 F.2d 631 (2d Cir. 1946); American Mint Corp. v. Ex-Lax, Inc., 263 App. Div. 89, 31 N.Y.S.2d 703 (1st Dep't 1941).

171. INT. Rev. Code of 1939, \$117 (a) (1) (A); INT. Rev. CODE OF 1954, \$1221 (1). Cf. Goldsmith v. Commissioner, 143 F.2d 466 (2d Cir. 1944), affirming, 1 T.C. 711 (1943), cert. denied, 323 U.S. 774 (1944) ; Fields v. Commissioner, 189 F.2d 950 (2d Cir. 1951), offirming, 14 T.C. 1202 (1950).

172. See authorities cited note 51 supra.

173. I.e., where the parties do not themselves allocate part of the sales price to the intangible as something distinct from good will.

174. "[T] restrictive covenant, the implied obligation that the seller will not solicit his old customers or do any act that would interfere with the vendee's use and enjoyment of that which he had purchased" Cooper \& Co. v. Anchor Securities Co., 9 Wash.2d 45, 55, 113 P.2d 845, 850 (1941), quoted with approval in D. K. MacDonald, 3 T.C. 720, 723 (1944). See also Von Bremen v. MaciIonnies, 200 N.Y. 41, 93 N.E. 186 (1910).

175. See, e.g., Beals' Estate v. Commissioner, 22 F.2d 268, 270 (2d Cir. 1936) : ("A promise not to work for others or for oneself is no more a conveyance of property than is a promise to enter the promisee's employ. Payment for either promise is income, not procecds received on disposal of a capital asset."); Cox v. Helvering, 71 F.2d 987 (D.C. Cir. 1934). 
by Aaron Michaels. ${ }^{176}$ There the entire profit upon the sale of a one-man laundry business (except for profit from its inventory of linens) was held to be capital gain, even though the taxpayer purported to sell his customer lists, good will, and a covenant not to compete. The Tax Court reasoned:

"Where [the covenant] accompanies the transfer of good will in the sale of a going business and it is apparent that [it] has the function primarily of assuring to the purchaser the beneficial enjoyment of the good will which he has acquired, the covenant is regarded as nonseverable and as being in effect a contributing element to the assets transferred."177

A distinction between "ancillary"178 and independent covenants has little economic substance, ${ }^{179}$ but the appellate courts may hesitate to deny capital gains status to "ancillary" covenants because of the practical difficulty of allocating sales proceeds between such a covenant and the other intangibles of an unincorporated ${ }^{180}$ business when capital or location have contributed just as much as the owner's personal activities toward the value of the intangibles..$^{181}$

\section{Professional Practices}

Since the good will of a professional practice ordinarily is due almost exclusively to personal effort and the allocation problem is diminished, the courts have been less inclined to find capital gains on the sale of a practice.

Cf. Estate of Mildred K. Hyde, 42 B.T.A. 738 (1940). See also Clarence C. Hamlin Trust, 19 T.C. 718 (1953), aff'd, 209 F.2d 761 (10th Cir. 1954).

176. 12 T.C. 17 (1949).

177. Aaron Michaels, 12 T.C. 17,19 (1949). Similar decisions: Ethel M. Cox, 17 T.C. 1287 (1.952) ; Cox v. United States, 99 F. Supp. 518 (D.C. Ariz. 1951); Toledo Newspaper - Co., 2 T.C. 794 (1943). Cf. Toledo Blade Co., 11 T.C. 1079 (1948), aff'd per curiam, 180 F.2d 357 (6th Cir.), cert. denied, 340 U.S. 811 (1950).

178. " $[\mathrm{T}]$ he agreement to refrain from competition should be treated as a capital asset ancillary to the transfer of good will and customers." Aaron Michaels, 12 T.C. 17, 20 (1.949).

179. "When a man buys a business, he bargains for future extra profits. The seller gets part of the expected future profits in the present because he built up the intangible assets that will bring them. Agreeing not to compete, the seller promises not to seek the return of his early labors for himseif. The net effect is a reallocation of future incomes between buyer and seller, whether there is a 'separable' covenant, an inseparable one, or no covenant at all. Hence, there is no justification for taxing the sale of 'good will' as a capital gain while the sale of a promise not to compete may result in ordinary income." Pines, Federal Income Taxation of Intangible Assets, 8 TAx L. REv. 231, 237 (1953).

180. Under present case law it is hard to predict when a covenant by the stockholders of a closely-held corporation would be "ancillary" to the sale of the good will of the corporation or "independent" and taxable as ordinary income under Beals' Estalc, supra notc 175. Compare George H. Payne, 22 T.C. No. 66 (1954) (capital gain computed on full sales proceeds despite allocation of part to stockholders' covenant not to compete), with Hamlin's Trust v. Commissioner, 209 F.2d 761 (10th Cir. 1954) (portion of price allocated to stoclsholder's covenant taxed as ordinary income).

181. For a possible legislative solution of this problem, see Pines, supra note 179, at 238. 
In E. C. O'Rear, ${ }^{182}$ three attorneys formed a partnership with all fees to be shared equally. O'Rear received $\$ 25,000$ from each of the others in recognition of the "conceded excess value of good will and unearned [sic] fees of said O'Rear put into the firm." 183 On the theory that he had sold good will built up in his individual law practice, O'Rear contended that no part of the $\$ 50,000$ was taxable income because it did not exceed the value of his practice on March $1,1913,{ }^{184}$ and, in the alternative, that any gain was capital gain. The Board of Tax Appeals rejected these contentions because: a professional man cannot transfer his reputation; O'Rear failed to prove the March 1, 1913 value of his practice; the formation of the partnership did not purport to be a sale ; ${ }^{-185}$ and the same result could have been accomplished by giving O'Rear a larger share of partnership income. ${ }^{186}$ The $\$ 50,000$ was held to be an advance payment of partnership profits taxable as ordinary income.

Although O'Rear and several other cases suggest that a professional practice can never possess vendible good will as a matter of law, ${ }^{187}$ two recent Tax Court decisions treat the rule as merely a presumption of fact which can be overcome by evidence that the parties genuinely believed good will existed and bargained for its sale. ${ }^{188}$ In Richard $S$. Wyler, ${ }^{180}$ a Kansas City accountant became a local partner of Peat, Marwick, Mitchell \& Co., a nationwide accounting firm, under an agreement by which he was to receive $\$ 10,000$ per year plus one percent of Peat, Marwick's net profits. In addition, Peat, Marwick

182. 28 B.T.A. 698 (1933).

183. E. C. O'Rear, 28 B.T.A. 698,699 (1933).

184. Revenue Act of 1921, $\$ 202($ b), 42 StAT. 229 (1921), corresponding to Irr. REv. CODE OF 1939, § 113 (a) (14) ; INT. REv. CODE OF 1954, § 1053.

185. The agreement referred to the payments as "a differential in division of fees and income of the firm business." E. C. O'Rear, 28 B.T.A. 698, 699 (1933).

186. "Compensation for personal services is income regardless of whether it is paid directly by clients or whether it is received through an arrangement with partners whereby they advance certain amounts for the privilege of taking a larger share of the partnership profits than their personal contribution would otherwise justify." Id. at 701.

187. D. K. MacDonald. 3 T.C. 720, 727 (1944) (insurance agency : "good will does not adhere to a business or profession, dependent solely on the personal ability, skill, integrity or other personal characteristics of the owner.") ; Charles F. Coates, 7 T.C. 125, 134 (1946) (accounting firm: "Ordinarily no value, or nominal value, will be given to good will attaching to a personal service partnership such as one composed of physicians, attorncys or accountants.") ; Estate of Thomas F. Remington, 9 T.C. 99 (1947) (insurance agency: Coates followed). See also John Q. Shunk, 10 T.C. 293 (1948), revid on ofher grounds, 173 F.2d 747 (6th Cir. 1949). The tax cases reflect the substantive rule of Bailly v. Betti, 241 N.Y. 22, 26, 148 N.E. 776, 777 (1925) (name of the Flonzaley Quartet held not a salable asset: "It has, however, never been held that a business dependent solely on ... personal skill and professional qualifications of the persons carrying it on possessed a good will or co-partnership name, which could be sold . . . . The contrary proposition is abundantly established [citing cases].").

188. Rodney B. Horton, 13 T.C. 143 (1949) ; Richard S. Wyler, 14 T.C. 1251 (1950), discussed by the taxpayer in Wyler, Tax Court Says Goodatill Attaches to Accoumting Practice and May Be Sold, 90 J. of Accountancy 242 (1950).

189. 14 T.C. 1251 (1950). 
paid him $\$ 50,000$ in cash for his practice-principally workpapers and good will-and for an "ancillary" covenant not to solicit the clients of Peat, Marwick, including his former clients, for three years after he should cease to be a partner. ${ }^{190}$ The Tax Court held that the entire $\$ 50,000$ was capital gain to Wyler, rejecting the Commissioner's contentions that a professional man cannot sell good will and that the $\$ 50,000$ was an advance payment of compensation, either for Wyler's services while a partner or for his covenant not to compete thereafter. ${ }^{101}$ Instead the court found from the testimony, particularly that of Wyler's partners, that his accounting practice, or its good will, ${ }^{102}$ was considered a salable asset by the parties, ${ }^{103}$ that the entire $\$ 50,000$ was intended only as its purchase price, ${ }^{194}$ and that the covenant merely ensured the purchaser's enjoyment of the good will. This testimony was doubtless given great weight because, by characterizing the transaction as a purchase of good will, Wyler's partners forswore all tax benefit to themselves from the $\$ 50,000$ payment, as a distribution of partnership profits, ${ }^{105}$ through amortization, ${ }^{100}$ or perhaps even as a loss if the firm should terminate its existence. ${ }^{107}$

The result of the $W y$ ler decision is that $\$ 50,000$ of potential income was taxed not once, as ordinary income to Wyler, but twice, first as capital gain to Wyler and later as ordinary income to his partners when realized by the firm. Although

190. Richard S. Wyler, 14 T.C. 1251, 1256 (1950). Wyler received separate consideration for the sale of his office equipment, library, and supplies. Id. at 1255.

191. The agreement in E. C. O'Rear, 28 B.T.A. 698 (1933), was distinguished because it did not purport to be a "sale." Id. at 1261.

192. The court agreed with both taxpayer and Commissioner that the terms "accounting practice" and "good will" were here synonymous and noted "the probability that the customers of the old establishment will continue their patronage." Id. at 1259.

193. Evidence was introduced at the trial that accounting practices are often bought and sold. See Wyler, supra note 188, at 245.

194. In Rodney B. Horton, supra note 188, the Tax Court arbitrarily halved the proceeds of the sale of an accounting practice, taxing half representing good will at capital gain rates and the other half representing the seller's covenant not to compete as ordinary income. No such allocation was made in Wyler, apparently because the narrower scope of Wyler's covenant made it "ancillary" to the sale of his practice. See text at note 190 supra.

195. Compare Carol F. Hall, 19 T.C. 445 (1952), zrith N. Paul Kenworthy, 11 T.C.M. 60 (1952).

196. U.S. Treas. Reg. 118, $\$ 39.23(1)-3$ (1953) : "No deduction for depreciation, including obsolescence, is allowable in respect of good will." Rotan v. Commissioner, 56 F.2d 153 (5th Cir. 1932). Cf. R. Bryson Jones, 17 B.T.A. 1213 (1929) ; Bills Bros. Memorial Corp., 7 B.T.A. 1182 (1927).

Because of this rule the purchaser of a going business has not been permitted to amortize any part of the cost attributable to the seller's "ancillary" covenant not to compete. Toledo Blade Co., 1.1 T.C. 1079 (1948) ; Harold J. Burke, 18 T.C. 77 (1952). Cf. Gazette Telegraph Co., 19 T.C. 692 (1953) (covenant held "independent" and therefore subject to amortization by the purchaser).

197. Harry C. Weeks, 1 T.C.M. 151 (1942). There a lawyer was denied a loss deduction for the amount paid to his partner for good will on the termination of the partnership. The court reasoned that the taxpayer had failed to prove that he was not still "enjoying the benefits of the original good will" purchased by him, even though he had moved his law practice to another city. Id. at 154. 
this type of "double tax" is not unique, 198 and presumably was reflected in the terms of the bargain, ${ }^{199}$ the resultant tax-shifting is illogical. Since Wyler would have had no salable asset without the covenant to refrain from soliciting former clients, the "capital asset" nature of his business depended upon the covenant, which, had it not been "ancillary" to the asset, would have given rise to ordinary income. Thus, apart from the question whether capital gains taxation is appropriate, the $W$ yler decision can be criticized for its circular reasoning. ${ }^{200}$

\section{PARTNERShIP INTERESTS}

During the past decade the courts ${ }^{201}$ and the Commissioner ${ }^{202}$ have adopted the view that a partnership interest is a single "capital asset" even though composed of fractional interests in partnership assets, some of which could not qualify separately as "capital assets."203 This rule has made it possible for a partner to sell his interest in the firm and enjoy capital gains on those personal efforts which have produced good will, appreciated inventory, and possibly

198. Ever since United States v. Phellis, 257 U.S. 156 (1921), one who purchases corporate stock "dividend on" is fully taxable on the dividend even though it consists of profits earned before the purchase and can be said to represent a return of capital to the purchaser. See U.S. Treas. Reg. 118, \$ 39.22(a)-1 (d) (1953).

199. Wyler and his partners were aware of the tax consequences of their actions. This is not always the case. See, e.g, Clarence C. Hamlin Trust, 19 T.C. 718, 725 (1953) (dissenting opinion).

200. Such circular reasoning has a distinguished pedigree. See Holmes, J. in Cincinnati Packet Co. v. Bay, 200 U.S. 179, 184-5 (1906): "It is said that there is no sale of good will. But the covenant makes the sale. Presumably all that there was to sell, beside certain instruments of competition, was the competition itself, and the purchasers did not want the vendors' names."

201. Except for City Bank Farmers Trust Co. v. United States, 47 F. Supp. 98 (Ct. Cl. 1942), the court decisions appear unanimous: United States v. Shapiro, 17S F.2d 459 ( Sth Cir. 1949) ; Bass v. Commissioner, 175 F.2d 52 (5th Cir. 1949) ; Long v. Commissioner, 173 F.2d 471 (5th Cir.), cert. denied, 338 U.S. 818 (1949); Commissioner v. H. R. Smith, 173 F.2d 470 (5th Cir. 1949), affirming, 10 T.C. 398 (194S), cert. denied, 338 U.S. 818 (1949); Commissioner v. Lehman, 165 F.2d 383 (2d Cir. 1948), cert. desticd, 334 U.S. 819 (194\$); United States v. Landreth, 164 F.2d 340 (5th Cir. 1947); Commissioner v. Shapiro, 125 F.2d 532 (6th Cir. 1942) ; Joseph Pursglove, 20 T.C. 68 (1953) ; Aaron Lowenstein Estate, 12 T.C. 694 (1949), aff'd sub nom. First Nat. Bank of Miobile v. Commissioner, 183 F.2d 172 (5th Cir. 1950), cert. denied, 340 U.S. 911 (1951) ; Daniel Gartling Estate, 6 T.C.X. 879 (1947), aff'd, 170 F.2d 73 (9th Cir. 1948); George H. Thornley, 2 T.C. 220 (1943); Dudley T. Humphrey, 32 B.T.A. 280 (1935).

202. G.C.M. 26379, 1950-1 Cux. Bulc 58, 59. This ruling limits capital gains treatment "to those cases in which the transaction in substance and effect, as distinguished from form and appearance, is essentially the sale of a partnership interest."

203. The "single capital asset" rule is contrary to the rule of Williams a. MicGouten, discussed in text at note 145 supra (sale of a sole proprietorship is a sale of each component asset). Its corollaries are: (1) A retiring partner's basis is his investment in the firm rather than a fraction of the firm's basis for each asset; but see INT. Rxv. CODE of 1954, $\$ 705(b)$, referred to in note 205 infra. (2) His holding period runs from the acquisition of his partnership interest rather than from the firm's acquisition of the underlying assets. 
also uncollected fees. The 1954 Code codifies the "single capital asset" rule but sharply curtails its tax advantages to the withdrawing partner.

In general, the interest of a withdrawing partner consists of his share of one or more of the following:

(1) Capital account (ordinarily the partner's financial investment in the firm's tangible assets).

(2) Good will.

(3) Undistributed income realized and taxed in prior years.

(4) Income realized in the current tax year up to the date of withdrawal and not yet taxed.

(5) Potential income of the current or a prior year, unrealized under the firm's regular method of accounting before the date of withdrawal, and consisting of

(a) Appreciation in the value of firm assets (including stock-in-trade, real and depreciable property used in the business, and capital assets).

(b) Fees for services partly or completely performed by the firm.

\section{Payments other than for Unrealized Income}

The 1954 Code makes statutory the Tax Court rule that, even though the purchase price of a partnership interest reflects the withdrawing partner's undistributed share of current earnings (item 4), he is taxed on this share at ordinary rates. ${ }^{204}$ This amount is then added to his basis for his partnership interest which consists of his capital investment (item 1) plus previously taxed undistributed income of prior years (item 3). ${ }^{205}$ Any profit on the sale

204. INT. Rev. Code of 1954, \&706(c) (2). See H.R. Rep. No. 2543, 83d Cong., 2d Sess. 60-1 (1954). George F. Johnson, 21. T.C. 773 (1954); Standard Paving Co., 13 T.C. 425 (1949), aff'd, 190 F.2d 330 (10th Cir.), cert. denied, 342 U.S. 860 (1951); Louis Karsch, 8 T.C. 1327 (1947) ; Charles Goodman, 9 T.C.M. 789 (1950) ; Robert S. LeSage, 6 T.C.M. 1263 (1947), aff'd, 173 F.2d 826 (5th Cir. 1949). Contra: Meyer v. United States, 213 F.2d 278 (7th Cir. 1954). (Capital gains treatment granted to selling partner's share of undistributed earnings accruing after close of partnership's last fiscal year and before date of sale.)

Since the partnership books are usually not "closed" until the end of the firm's regular year, the retiring partner's share is computed by taking a fraction of the full year's profit. Abe Globman, P-H 1947 TC MEM. DEC. If 47,261 (1941). Where the books were "closed" on or about the date of retirement, his share has been computed on the profit from operations during the pre-retirement period, irrespective of events during the remainder of the year. Louis Karsch, stupra.

205. Under the 1954 Code, the unadjusted basis of a partner's interest is his contribution of money and property ( $\$ 722)$, the price paid by him to purchase the interest of a retiring partner, or the estate tax value of an interest inherited by him $(\$ 742)$. The unadjusted basis is then adjusted, primarily by being increased by his share of partnership income and decreased by his share of partnership losses and distributions ( $\$ 705)$. These principles are substantially a codification of pre-1954 practice as summarized in U.S. Treas. Reg. 118, $\$ 39.113$ (a) (13)-2(a) (1953). See SEN. Rep. No. 1622, 83d Cong., 2d Sess. 384 (1954). The 1954 Code introduces an "alternative rule" whereby the adjusted basis of a partncr's interest may be determined "by reference to his proportionate share of the adjusted basis of partnership property upon a termination of the partnership." ( $\$ 705(b))$. 
is necessarily attributable to his interest in good will (item 2) or unrealized income (item 5). ${ }^{206}$

The 1954 codification of the rule that a partnership interest is a single capital asset ${ }^{207}$ facilities capital gains on the good will of a partnership. ${ }^{203}$ It brings no new tax advantage to the withdrawing partner of a manufacturing or merchandising firm because his share of good will would be treated as a capital asset even if he were regarded as selling a fractional interest in each of the firm's assets. ${ }^{209}$ But the withdrawing member of a professional or other personal service partnership is freed of the uncertainty over whether the good will of his enterprise can separately qualify for capital gains treatment. 210

\section{Paynuents for Unrealized Income prior to the 1954 Code}

\section{Tax Treatment of Selling Partuer}

The treatment of a partnership interest as a single capital asset under pre1954 law enabled a withdrawing partner to obtain capital gains on any payment attributable to his share of the potential income in the form of appreciated stock in trade. In the case of the typical small manufacturing or merchandising partnership, the appreciation of stock in trade is often the product of the partners' business ability and activities as well as their capital.

Pre-1954 law was much less certain that the sale of an interest in a professional or other personal service partnership would convert into capital gain the withdrawing partner's share of potential income represented by work in process and uncollected fees. ${ }^{211}$ If a member of a personal service partnership has neither a capital investment in the firm ${ }^{212}$ nor an interest in partnership good will, ${ }^{213}$ he has nothing more to sell than his share of profits earned but

206. If the withdrawing partner previously purchased his interest in good will or unrealized income, his basis for his partnership interest was increased, reducing his ultimate gain.

207. INT. REv. CODE OF 1954, $\$ 741$.

208. If a partner receives payments from his firm in "liquidation of a partner's interest" instead of selling his interest, INT. REv. CODE of 1954, $\$ 736$ (b) (2) makes ordinary income of the amount attributable to "good will of the partnership, except to the extent that the partnership agreement provides for a payment with respect to good will." SEN. REP. No. 1622, 83d Cong., 2d Sess. 395 (1954) states that "[w]here the partnership agreement provides for payments with respect to good will, such payments may not exceed the reasonable value of the partner's share of partnership good will." Cf. $\$ 736(\mathrm{~b})(2)(B)$ of H.R. 8300 (House Bill).

209. See authorities cited in note 147 supra.

210. See discussion of $O^{\prime} R e a r, W y l e r$, and similar cases in text at notes $182-200$ supro.

211. In the case of accrual-basis partnerships such fees are those not accruable before the partner's withdrawal.

212. A partner has no capital investment when the firm operates without capital, c.g., by using office furniture and equipment belonging to the partners individually, or when he is a "junior" partner sharing in profits and losses with all of the firm's assets belonging to its "senior" partners.

213. A withdrawing partner may have no interest in partnership good will either because the partnership agreement provides that good will, e.g., the firm name, shall belong to the remaining partners, or because good will may belong to the individual partners rather 
unrealized before his withdrawal. The leading case of Bull $v$. United Statcs 214 held that a partner's naked right to such income could not be sold and that payment received for the right was taxable as an advance distribution of profits. ${ }^{216}$ The Bull decision involved a payment made to the estate of a deceased partner, but its reasoning was extended in Helvering $v$. Smith $\$ 10$ to a payment to a withdrawing partner for his share of fees earned and uncollected at the time of his withdrawal. Under the partnership agreement all other assets of the firm, e.g., its library and office equipment, were to belong to the remaining - partners. In holding that the withdrawing partner received ordinary income, Judge Learned Hand reasoned:

"The transaction was not a sale because he got nothing which was not his, and gave up nothing which was. Except for the 'purchase' and release, all his collections would have been income; the remaining partners would merely have turned over to him his existing interest in earnings already made .... The 'purchase' of that future income did not turn it into capital, any more than the discount of a note received in consideration of personal services .... Nobody would suggest that the sale of a declared dividend payable in the future turns the cash received into capital."217

The Sinith decision had been approved by the lower courts, ${ }^{218}$ the Commissioner, ${ }^{219}$ and possibly the Supreme Court, ${ }^{220}$ when the Seventh Circuit rejected it in Swiren v. Commissioner. ${ }^{221}$ A lump-sum payment of $\$ 40,000$ had been made to a withdrawing partner for his interest in the uncollected fees of a cash-basis law partnership. Unlike Smith, Swiren had spent over $\$ 18,000$ to

than the firm under state law. See, e.g., In re Martin's Estate, 178 Misc. 43, 33 N.Y.S.2d 81 (Surr. Ct. 1941) ; Master v. Brooks, 132 App. Div. 874, 117 N.Y. Supp. 585 (1st Dep't 1909); Magee v. Pope, 234 Mo. App. 191, 112 S.W.2d 891 (1938).

214. 295 U.S. 247 (1935).

215. "Where the effect of the contract is that the deceased partner's estate shall leave his interest in the business and the surviving partners shall acquire it by payments to the estate, the transaction is a sale .... Here, however, the survivors have purchased nothing belonging to the decedent, who had made no investment in the business and owned no tangible property connected with it. The portion of the profits paid his estate was, therefore, income ...." Bull v. United States, 295 U.S. 247, 254 (1935).

216. 90 F.2d 590 (2d Cir. 1937).

217. Helvering v. Smith, 90 F.2d 590, 592 (2d Cir. 1937).

218. See, e.g., Richard S. Doyle, 37 B.T.A. 323 (1938), aff'l, 102 F.2d 86 (4th Cir. 1939) ; James Wesley McAfee, 9 T.C. 720 (1947). Cf. Paul W. Trousdale, 16 T.C. 1056 (1951).

219. "Payments made to a retiring partner which represent his distributive share of earnings for past services should be treated as ordinary income rather than the procecds derived from the sale of his interest [citing the Smith, Doyle, and MfcAfec cases]." G.C.M. 26379, 1950-1 Cum. Bull. 58.

220. The Supreme Court did not cite the Sinith case in Hort v. Commissioner, 313 U.S. 28 (1941), discussed in text at notes 120-2 supra, but its "substitute for ordinary income" theory is virtually identical with the quote from Judge Hand's opinion in text at note 217 supra.

221. 183 F.2d 656 (7th Cir. 1950), reversing, 8 T.C.M. 924 (1949). 
purchase the interest of other partners in the firm's name and tangible assets. Reversing the Tax Court holding that the $\$ 22,000$ gain was compensation for past services, the Seventh Circuit treated the entire $\$ 40,000$ as the proceeds of the sale of his partnership interest and held the profit to be capital gain.Other circuits have not yet chosen between Swircu and the Bull-Smith line of cases, but the weight of argument disfarors capital gains on a payment for uncollected fees even when the withdrawing partner has a substantial capital investment in the firm. Swiren conflicts with authorities which deny capital gains on the proceeds of an assignment of rights to income from past services. Furthermore, it invites sale of partnership interests for tax avoidance purposes. ${ }^{224}$ And finally, it puts the purchaser of the partnership interest in an unfair and illogical position.

\section{Tax Treatment of Buying Partner}

The consequence of the withdrawing partner's capital gains on stock in trade and uncollected fees under pre-1954 law was a severe tax burden on the purchaser of his interest. The payment to the withdrawing partner did not affect the computation of firm income ${ }^{225}$ or the distributive shares of the partners, including the buyer, but represented a capital investment in the firm by the buyer-from which he often obtained little or no tax benefit. ${ }^{220}$ When the firm realized the income "sold" by the retiring partner, the buyer was taxed on his distributive share even though it represented no economic gain to him but was merely the return of his investment. Thus, what was economically the seller's income was taxed to the buyer at ordinary rates while the seller received the same amount as capital gain.

This hardship to the buyer could have been mitigated by treating part of the sales proceeds as an advance payment of partnership profits.227 This was done with respect to the seller by the Tax Court in the Swiren case ${ }^{203}$ even in the

222. The opinion assumes that a partner cannot realize ordinary income in excess of his share of currently distributable partnership income, which in the case of Swiren's cash-basis partnership did not inciude the uncollected fees. Swiren v. Commissioner, 183 F.2d 656, 660 (7th Cir. 1950).

223. See text at notes 95-101 sipra.

224. See Doyle v. Commissioner, 102 F.2d 86, 88 (4th Cir. 1939). See also Little, Federal In COAIE Taxation of Partinerships 257-9 (1952).

225. Under INT. REv. CODE of 1939, \$113(a) (13) the partner's basis for his partnership interest was not allocable to firm assets until they were distributed to the partners in their individual capacity.

226. The buyer would derive no tax benefit from his high basis for his partnership interest unless he later sells or liquidates. If he retains his interest until his death, his executor or legatee obtains a new basis equal to the then fair market value of the partnership interest. INT. Rev. Code of 1939, \$113(2) (5) ; INT. REv. CoDE of 1954, §1014(a).

227. This solution is suggested by Rabkin \& Johnson, The Parlnerslip under the Federal Tax Law's, 55 Harv. L. Rev. 909, 94S (1942). See also U.S. Treas. Reg. 118, $\$ 39.126$ (c), Example (1953) (allocation of payment to estate of dcceased partner).

228. Max Swiren, \& T.C.M1. 924 (1949), rev'd, 183 F.2d 656 (7th Cir. 1950). 
absence of a contractual allocation by buyer and seller. ${ }^{229}$ Earlier, in Raymond S. Wilkins, ${ }^{230}$ where a professional partnership had purchased a former partner's share of earned but uncollected fees from his estate, the Tax Court had refused to allow the remaining partners to reduce their income by the amount paid to the estate, but had stated by way of dictum:

"[I]n future periods as the fees are collected they will not be income in toto to the partnership, but only to the extent that they exceed the pro rata part of the capital outlay allocable thereto; and, if they do not exceed, but are less, a loss will result." ${ }^{231}$

Implicit in this dictum is the assumption that the commutation payment was taxed as ordinary income to the estate under the Bull-Smith line of cases. But where a withdrawing partner pays only a capital gains tax, the courts logically could not exclude the collections from the income of the buyers, for then the fees would be ordinary income to no one. Thus the remaining partners would probably be denied the benefit of the Wilkins dictum under the Seventh Circuit decision in Swiren, although they might have been permitted to write off the amount taxed to Swiren as ordinary income under the Tax Court decision. 23

\section{"Collapsible Partnerships"}

The general adverse tax consequences to a purchaser of unrealized partnership income prior to the 1954 Code were not, however, a deterrent to the "collapsible partnership."233 Modeled after the "collapsible corporation,"284 this device involved the formation of a partnership to produce or purchase property the income from which would not qualify as capital gain, followed by a sale of the partnership interest before realization of the income by the partnership. ${ }^{235}$ The purchaser then liquidated the partnership and obtained the

229. Allocations by the parties were involved in: Courtland N. Smith, 9 T.C.M. 1084 (1950) ; Sidney Hess, 12 T.C. 773 (1949); Charles F. Coates, 7 T.C. 125 (1946) ; Richard P. Hallowell, 39 B.T.A. 50 (1939).

230. 7 T.C. 519 (1946), aff'd, 161 F.2d 830 (1st Cir. 1947).

231. Raymond S. Wilkins, 7 T.C. 519, 524 (1946). No such offset was permitted in the Wilkins case because of failure of proof of the amounts of the purchased fees collected during the year in controversy. Although the Wilkins dictum involved a payment occasioned by the death of a partner, it seems equally applicable to a payment to a withdrawing partner. See Lawrence W. Zonsius, P-H 1941 BTA MEN. DEc. \4 41,313 (1941).

232. Max Swiren, 8 T.C.M. 924 (1949), rev'd, 183 F.2d 656 (7th Cir. 1950). See Little, Payments by a Partnership to Former Partners or Their Estates, 31 TAxEs 439, 475 (1953).

233. For a discussion of the use of collapsible partnerships to produce motion picturcs, see Walker, Investing in Motion Picture Enterprises, 1954 U. So. Caurr. Tax INST. 399.

234. See text at notes 59-66 supra and 421-74 infra.

235. Unlike "collapsing" a corporation, liquidating a partnership by distributing the assets to the original partners would not achieve the desired result because it was not a taxable event; instead, each individual partner would be required to allocate the basis of his partnership interest among the various assets in proportion to their market values at the time of the distribution. INT. Rev. CoDE of 1939, $\S 113$ (a) (13) ; U.S. Treas. Reg. 118, $\$ 39.113$ (a) (13)-2 (1953); G.C.M. 20251, 1938-2 CuM. Bulz. 169. Any cash distributed 
property at a basis equal to the price paid for his partnership interest.230 Amortization of this high basis would offset subsequent income from the property.

The seller's prospect of capital gains was subject to several risks. Immediate liquidation of the partnership might have resulted in ordinary income to the seller under Paul $W$. Trousdale. ${ }^{237}$ That case denied capital gains on the sale of an interest in a partnership in liquidation on the ground that there had been no sale of a "capital asset" but only an assignment of the taxpayer's distributive share of partnership income and other assets. And the risk would be increased if none of the original partners remained in the firm because of the tenuous distinction between a simultaneous sale of the "capital asset" partnership interest of each partner and a sale by the partnership of all of its assets, capital and non-capital. Capital gains treatment has been granted on the basis of this distinction to sales of long-established partnerships, ${ }^{23 s}$ even where the business was purchased by an individual ${ }^{230}$ or a corporation,, but these precedents are distinguishable from the preconceived sale of an interest in a temporary partnership. ${ }^{241}$ Finally, capital gains might have been denied on the grounds that an interest in a collapsible partnership was "property held ... primarily for sale to customers" 242 or that part of the sales proceeds represented payment for inadequately compensated services previously rendered to the partnership. ${ }^{243}$

\section{Paynents for Unrealized Income under the $195+$ Code}

The 1954 Code sharply restricts the rule that a partnership interest is a single capital asset.244 If the partnership interest includes a share of "unrealized receivables of the partnership" or "inventory items of the partnership which have appreciated substantially in value," 245 part of the payment received

reduced the basis of the partnership interest to be allocated among the non-cash assets. I.T. 2010, III-1 CUar. BULI. 46 (1924). Where only cash was distributed, ordinary gain or loss was recognized to the extent that the cash exceeded the basis of the partnership interest because the distribution was not a sale or exchange.

236. INT. Rev. Code of 1939, \$113(a) (13). See Jackson, ct al., A Proposed Revision of the Federal Income Tax Treatment of Partnerships and Partners-American Low Institute Draft, 9 TAX L. REv. 109, 145 (1954) : “[T] ]he 'collapsible partnership' device of obtaining the step-up in basis by dissolving the partnership after the sale is fast replacing the "collapsible corporation' ... as a means for converting ordinary income into capital gain."

237. 16 T.C. 1056 (1951).

238. Mignonette E. Luhrs, 9 T.C.M. 537 (1950).

239. Hatch's Estate v. Commissioner, 198 F.2d 26 (9th Cir. 1952).

240. Ed Krist, 12 T.C.M. 801 (1953) ; Kaiser v. Glenn, 54-2 U.S. TAx CAs. I 9621 (6th Cir. 1954), reversing 114 F. Supp. 356 (D.C. Ky. 1953).

241. See note 202 supra.

242. Cf. Altman, Collapsible Corporations, 28 TAXes 1013, 1014 (1950). The fact that the taxpayer had made no prior sales of partnership interests would not necessarily prevent this result. See, e.g., Goldsmith v. Commissioner, 143 F.2d 466 (2d Cir. 1944).

243. See note 219 supra.

244. INT. Rev. CODE OF 1954, § 741.

245. Id. $\$ 751(\mathrm{a})$. 
and part of the basis of the selling partner's interest ${ }^{240}$ are attributed to the receivables or inventory items, and the gain computed from these amounts is ordinary income, while the rest of the profit is capital gain. The term "un" realized receivables" is defined to "include" any rights, contractual or otherwise, to ordinary income from "services rendered, or to be rendered," 247 and "goods delivered, or to be delivered"248 to the extent that such rights were not previously includible in income under the method of accounting used by the partnership. In contrast to this nonexclusive definition, the term "inventory items" is defined to "mean" most, but not all, types of non-capital assets, ${ }^{249}$ including property held by the partnership which would not qualify for capital gains treatment if it had been held by the selling partner. "Inventory items" are deemed to have "appreciated substantially in value" if their fair market value exceeds both 120 percent of their basis to the partnership and ten percent of the fair market value of all partnership property other than money. ${ }^{250}$

The 1954 Code also prevents "unrealized receivables" and "inventory items" from receiving capital gains treatment through the medium of partnership distributions, whether the partnership is "collapsible" or long-established. The distribution rules have considerable importance because a partner's interest in the firm or some of its assets is often discharged by giving him firm assets rather than the personal funds of the other partners, new or old. $\Lambda$ partner's interest in partnership receivables or inventory can be satisfied by (a) a distribution in kind of his pro rata share of the assets themselves, (b) a distribution in cash equal to the value of his share, (c) a distribution of other non-cash assets equal in value, or (d) a combination of the foregoing.

If the firm makes a distribution in kind of a partner's share of "unrealized receivables" or "inventory items," 251 no tax is incurred by either the firm or the partner at the time of the distribution. ${ }^{262}$ However, ordinary rates are

246. According to SEN. REP. No. 1622, 83d Cong., 2d Sess. 401 (1954), the partner's basis is to be allocated in proportion to his pro rata share of the firm's basis for the receivables or inventory.

247. INT. REv. CODE oF 1954, § 751 (c) (2).

248. Id. $\$ 751$ (c)(1). It is doubtful whether the phrase "goods delivered" is broad enough to include future rentals, royalties, and similar types of potential income of a "collapsible partnership" which constructs a building or produces a motion picture and has no inventory of "goods" in the narrow sense.

249. Id. $\$ 751$ (d) (2). Real and depreciable property used in the trade or business of the partnership is excluded from the category of "inventory items."

250. Id. $\$ 751$ (d) (1). The Senate "liberalized" the House Bill by basing the 10 percent test on fair market value rather than the adjusted basis of all partnership property other than money. Sen. Rep. No. 1622, 83d Cong., 2d Sess. 403 (1954). H.R. Rep. No. 1337, 83d Cong., 2d Sess. A114 (1954) (discussing the "collapsible corporation" provisions of H.R. 8300) provides some light on how fair market value of inventory items is to be determined.

251. With certain exceptions, the basis of the receivables or inventory in the distributee's hands is their basis to the partnership immediately prior to the distribution, whether or not the distribution is in liquidation of the partner's interest. Id. $\$ \$ 732$ (a), (b), (c).

252. Id. $\$ 731$ (a) (1) provides that in the case of a distribution by a partnership to a partner, "gain shall not be recognized to such a partner, except to the extent that any moncy 
imposed upon the distributee when he makes a "disposition" of the receivables ${ }^{203}$ or, within five years after the distribution, sells the "inventory items." 254

If the partner gives up all his interest in "unrealized receivables" or "inventory items" in consideration of a distribution consisting of other partnership assets or cash, there is deemed to have been a "sale or exchange" between the distributee and the partnership as it exists after the distribution.255 Under this rule the distributee realizes ordinary income as though he had sold his share of receivables or inventory to a third party, and the partnership realizes (usually capital) gain to the extent that it parts with property other than money in exchange for the distributee's interest in the receivables and inventory. ${ }^{256}$

If a partner receives a distribution in kind consisting of more than his share of receivables or inventory because he surrenders his interest in other types of partnership property, including money, the transaction is divided into two parts for the purpose of applying the distribution rules. ${ }^{257}$ Receivables or inventory up to his pro rata share are treated as a tax-free distribution in kind; receivables or inventory in excess of his share are deemed to pass in a "sale or exchange" between the distributee and the partnership as it exists after the distribution. ${ }^{25 s}$ Here the firm realizes ordinary income from the disposition of the receivables or inventory in excess of the distributee's share and the distributee realizes (usually capital) gain or loss at the time of the distribution to the extent that he parts with his share of partnership assets other than money, ${ }^{259}$ later realizing ordinary income or loss from the disposition of the receivables or inventory. ${ }^{260}$ The rules for disproportionate distributions may

distributed exceeds the adjusted basis of such partner's interest in the partnership immediately before the distribution."

253. Id. $\$ 735$ (a) (1). The mere collection of the receivables might not be a "disposition," but it could not give rise to capital gains because of the absence of a "sale or exchange." Cf., e.g., Helvering v. William Flaccus Oak Leather Co., 313 U.S. 247 (1941); Fairbanlss v. United States, 306 U.S. 436 (1939) ; Hale v. Helvering, 85 F.2d 819 (2d Cir. 1936 ).

254. INT. REv. CoDE of 1954, $\$ 735$ (a) (2). Whether capital gain would be realized upon a "disposition" after the five-year period would depend on whether the property was then a capital asset in the hands of the taxpayer and whether the disposition would qualify as a "sale or exchange" H.R. REp. No. 1337, 83d Cong., 2d Sess. A229 (1954).

255. INT. REv. CODE oF 1954, \$ 751 (b) (1) (B).

256. See Sen. Rep. No. 1622, 83d Cong., 2d Sess. 401-02 (1954) ; H.R. ReP. No. 2543, 83d Cong., 2d Sess. 64-5 (1954).

257. This is made clear by the Conference Report, H.R. ReP. No. 2543, 83d Cong., 2d Sess. 65 (1954). Fragmentation would also be required where the partner reccives less than his full share of receivables or inventory in kind and the balance in other proparty or ash.

258. INT. Rev. CODE OF 1954, § 751 (b) (1) (A).

259. The distributee's gain or loss is the difference between the value of the assets received by him and his share of the partnership's basis for the assets which he relinquishes. See H.R. REP. No. 2543, 83d Cong., 2d Sess. 65 (1954).

260. See notes 253,254 sipra. However, to the extent that the receivables and inventory are in excess of his share, his basis for them will be the value of the share of the partnership assets, including money, relinquished by him. 
also apply to payments by the firm in "liquidation of a partner's interest"201 when these payments are attributable to the withdrawing partner's interest in "inventory items." 262 The rules do not apply to payments to a retiring partner for his interest in "unrealized receivables," the latter being fully taxable as ordinary income whether or not the payments are disproportionate. .0J $^{\circ}$

Having thus attempted to prevent a partner from extracting his interest in receivables and inventory as capital gain rather than ordinary income, the 1954 Code also seeks to prevent the purchasing or remaining partners from paying a second tax on the amounts already taxed to the selling or distributec partner. ${ }^{264}$ No problem is involved as to receivables or inventory which the distributee receives in kind, because the partnership will never realize the income on these items. And the partnership will use as its basis for receivables and inventory acquired in a distribution treated as a "sale or exchange" the amount of cash or the value of the property distributed in exchange, so that its later income from the receivables or inventory will be only the excess over this basis. 265

If a partner's interest in receivables or inventory is acquired by purchase rather than by a partnership distribution and if the partnership so elects, ${ }^{200}$ the purchaser may compute his share of subsequent partnership profits, depreciation, and the like by using his own set of basis figures for the partnership assets. ${ }^{207}$ Thus where the purchaser has paid the withdrawing partner more than his share of the partnership's adjusted basis for the assets, such basis will be increased by the amount of this excess for the purpose of computing the purchaser's share of partnership income. ${ }^{268}$ The excess basis is to be allocated

261. This phrase is defined in INT. REv. CODE of 1954, $\$ 761$.(d) as "the termination of a partner's entire interest in a partnership by a distribution, or a series of distributions, to the partner by the partnership."

262. See Sen. Rep. No. 1622, 83d Cong., 2d Sess. 402 (1954). The amount taxable to the distributee may be different than in the case of a disproportionate nonliquidating distribution because "the basis to the distributee of the distributed properties will be determinted by reference to the basis of the distributee for his interest in the partnership under section 732(b), rather than under the provisions of section 732(a), relating to nonliquidating distributions." H.R. REP. No. 2543, 83d Cong., 2d Sess. 66 (1954).

263. See Sen. Rep. No. 1622, 83d Cong., 2d Sess. 402 (1954).

264. See text at notes 225-32 supra.

265. The principal exception to this rule is that to the extent that a distribution other than in receivables "in liquidation of a partner's interest," see note 261 supra, is attributable to his interest in receivables, the income of the remaining partners is reduced when the distribution is made, INT. REv. CoDE of 1954, §736(a), rather than later when the partnership realizes the income represented by the receivables.

266. The manner of election is described in $i d . \$ 754$ which provides, intcr alia, that the election shall apply to all future transfers and distributions until its revocation subject to limitations prescribed by the Secretary of the Treasury.

267. Similar treatment is available in the case of a transferee of a deceased partner's interest, id. $\$ 743(\mathrm{a})$, and in the case of a partnership making certain types of distributions to a partner, $i d . \S 734$ (b).

268. Id. $\$ 743$ (b) (1). The computation is illustrated in the Conference Report, H.R. Rep. No. 2543, 83d Cong., $2 \mathrm{~d}$ Sess. $61-4$ (1954). If the election has been made, a downward 
among the various classes of assets, e.g., inventory, depreciable assets, capital assets, to which it is attributable under a statutory sequence which reduces differences between their fair market values and adjusted bases. ${ }^{269}$ If the partnership does not make this election, the purchasing partner will derive no immediate benefit from the high basis for his partnership interest unless he receives a distribution of property, other than money, within two years after the purchase. If such a distribution occurs, the distributee is permitted to make an individual election to increase his basis for the distributed property to reflect his high basis for his partnership interest. ${ }^{270}$

The rules as to receivables and inventory were intended by the Ways and Means Committee "to prevent the conversion of potential ordinary income into capital gain by virtue of transfers of partnership interests."2ri And implicit in this statement is the fact that the partnership form is used primarily by small enterprises depending largely upon the activities of the individual partmers. Thus the new statute seems directed primarily against capital gains treatment of the fruits of personal effort, not only in "collapsible partnership":i2 schemes but also upon the severance of long-established partnership relationships.

\section{Corporate Stock}

Unquestionably the most common and effective means of reaping the fruits of personal effort as capital gain is a sale or redemption ${ }^{273}$ of corporate stock. The sale of a sole proprietorship can produce capital gains on good will attributable to the proprietor's individual activities. ${ }^{27 \%}$ The sale of a partnership interest results in capital gains on good will and, prior to the 1954 Code, on at least some types of unrealized income. ${ }^{275}$ The sale or redemption of corporate stock affords both of these advantages and makes possible a third, much more important-capital gains on income already realized. This benefit stems from the fact that, unlike a sole proprietor or a partner, a stockholder is not taxed

adjustment must also be made where the transferee's basis for his interest is less than his portion of the partaership's basis for its assets.

269. INT. REv. CODE OF 1954, \$ 755. The method of allocation is illustrated in SEN. REP. No. 1622, 83d Cong., 2d Sess. 397-401 (1954).

270. INT. REv. CODE of 1954, \$ 732(d). The adjustment may be required by regulation if at the time of the transfer the fair market value of all partnership property, other than money, exceeded 110 percent of its adjusted basis to the partnership, regardless of whether the distribution is made within two years after the transfer. See H.R. Rep. No. 2543, 83d Cong., 2d Sess. 61 (1954).

271. See H.R. REP. No. 1337, 83d Cong., 2d Sess. 70 (1954). See also Id. at 71.

272. Although the phrase "collapsible partnerships" is used in a caption in SE:. REp. No. 1622, 83d Cong., 2d Sess. 98 (1954), it is neither defined nor illustrated.

273. INT. REv. CODE of 1939, §115(c) provided that amounts distributed by a corporation in either complete or "partial" liquidation were to be treated as received by" the stoclholders in "exchange" for the stock surrendered by them. Under the 1954 Code a corporate distribution is treated as payment in exchange for stock if made in complete or partial liquidation ( $\$ \$ 31,346)$ or in certain "redemptions treated as exchanges" ( $\$ 302)$.

274. See text at notes 143-200 supra.

275. See text at notes 201-243 supra. 
on earnings until he withdraws them from the business; he thus can accumulate earnings within the corporation until a sale or redemption of the stock becomes convenient. ${ }^{276}$

There are many other ways in which the corporate form is superior for converting personal service income into capital gain. A sale of part or all of a sole proprietor's or partner's interest invariably involves a pro tanto severance of his interest in the future of the enterprise; in several ways the owner of a corporation can obtain capital gains without a comparable loss of interest. ${ }^{277}$ A sole proprietor or partner must first find a purchaser willing to pay a fair price for his interest; a controlling stockholder may receive capital gains directly from his corporation by causing it to redeem his stock. And stock redemptions are free of the price-depressing tax hardships often suffered by the purchaser of good will of a sole proprietorship, ${ }^{278}$ a partnership interest, ${ }^{270}$ or even corporate stock. ${ }^{280}$ Moreover, unlike a sole proprietorship or partnership, the corporation affords a feasible method of conferring capital gains not only upon the proprietors but also upon employees and outsiders such as

276. For other less important advantages see note 7 supra. The typical personal service enterprise operated as a sole proprietorship or a partnership will be unable to talic advantage of the election offered in the 1954 Code to be treated as a corporation for tax purposes. INT. REv. CODE of 1954, $\$ 1361$ (a) permits an unincorporated enterprise to elect to be considered a corporation "with respect to operation, distributions, sale of an interest, and any other purpose; and each owner of an interest in such enterprise shall be considered a shareholder thereof in proportion to his interest." But the enterprise must be "onc in which capital is a material income producing factor, or 50 percent or more of the gross income [is] income derived from trading. ..."Id. §1361(b) (4). See SEN. REP. No. 1622, 83d Cong., 2d Sess. 119 (1954): "This provision would rule out firms engaged in professional services such as the law, accounting, medicine, engineering and others." This report also states that capital is a material income-producing factor if the business requires a substantial inventory or a substantial investment in plant, machinery, or equipment. Id. at 456.

277. See text at notes 490-525 infra.

278. See text at notes 195-7 supra.

279. See text at notes $225-32$ supra.

280. See note 198 stipra. Liquidation of the corporation by noncorporate purchasers of common stock would avoid their being taxied on accumulated earnings, but under the 1939 Code even an immediate liquidation may not have been satisfactory in the case of a corporition purchasing at least 80 percent of the stock. INT. REv. CoDE of 1939, $\$ 112(\mathrm{~b})(6)$ and U.S. Treas. Reg. 118, $\$ 39.115$ (a) -3 (1953) seem to require the transferce corporation to take over the transferor's "earnings and profits." See also INT. Rev. CoDE of 1939, \$113 (a) (15) which may have required the corporate purchaser to use the liquidated corporation's basis for the assets even though less than the price paid for the stock. But see KimbellDiamond Milling Co. v. Commissioner, 187 F.2d 718 (5th Cir.), cert. denied, 342 U.S. 827 (1951) (denying purchaser the use of the old asset basis where in excess of the purchase price).

INT. REv. CODE OF 1954, $\S 334$ (b) (2) provides that if a corporation purchases at least 80 percent of the stock of another corporation within a twelve-month period and causes its complete liquidation within two years thereafter, the purchasing corporation shall use its adjusted basis for the stock as the basis of the assets distributed in the liquidation. Where $\S 334$ (b) (2) applies, $\$ 381$ (a) (1) prevents a carry-over of "earnings and profits" under $\S 381$ (c) (2). 
attorneys and brokers. ${ }^{281}$ Finally, corporate stock simplifies the problems encountered in other attempts to comply with the "capital asset" exchange" 283 requirements.

The capital gains advantages of doing business as a corporation are limited in important respects by both corporate and tax law. State laws prohibit corporations from practicing the learned professions and engaging in other licensed activities.284 Even if the enterprise can be operated as a corporation, its capital gains potentialities may be offset by any of at least four serious disadvantages: (1) The acquisition of stock may be taxed as compensation for personal services. (2) Under certain circumstances the current earnings of the enterprise may be taxed as belonging directly to the stochholder-employee in his individual capacity rather than to his corporation. (3) Taxes on corporate income may outweigh the tax savings of capital gains treatment of the stockholder. (4) Capital gains may not be worth a sacrifice of all or part of the taxpayer's equity in his business, if the stock is sold, or the inconvenience of operating it in unincorporated form, if the corporation is dissolved.

\section{Acquiring the Stock}

A cash purchase of stock is an "open transaction": even though the stock: may be worth more than its cost, the profit is not taxed until the stock is sold, and then usually at capital gain rates. ${ }^{285}$ This rule is applicable to a stock purchase, not only by a passive investor, but also by a person who performs services for the corporation. The latter will be taxed when he receives the stack only if the Commissioner can establish, as a fact, 280 that the stock is in payment for the services. ${ }^{287}$ Here ordinary income is realized to the extent that the stocl:

281. It seems improbable that employees and outsiders have been made partners with a view to capital gains on a subsequent sale of their partnership interests to the substantial owners of the business. The owners' inability to deduct the purchase price would have outweighed the limited tax benefit to the employee or outsider. And aside from taxes, owners would probably be unwilling to confer upon employees the broad authority of a general partner under the law of agency. Furthermore, state laws such as N.Y. PesisL Law $\$ 440$ may involve cumbersome filing requirements and unwanted publicity.

282. Corporate stock is ordinarily a capital asset unless held as stock in trade by a securities dealer. INT. Rev. CoDE of 1939, §117(n); INT. Rev. Code of 1954, §1236. See Miller, The 'Capital Asset' Concept: A Critique of Capital Gains Taxation, 59 YALE L.J. $837,848-51$ (1950).

283. See text at notes 111-128 supra.

284. See, e.g., N.Y. PENAL LAw $\$ 2 \S 0$ (practice of law by a corporation constitutes criminal offense). See also 6 Fletcher, Cyclopedia of tee Law of Private Conforatio:is $\$ 2523$ et seq. (1950), stating that corporations are generally not considered "persons" who may be licensed to practice a profession involving personal qualifications.

285. Palmer v. Commissioner, 302 U.S. 63 (1937).

286. To date the courts have refused to accept the conclusive presumption of U.S. Treas. Reg. 118, $\$ 39.22$ (a)-1(c) (1953) that the excess of stock value over the price paid by the employee is always in the nature of compensation as a matter of law, irrespective of the "facts" as to intent of the parties. See text at notes 321-31 infra.

287. Id. $\$ 39.22(\mathrm{a})-3$. 
value exceeds the cash and the current value of any non-cash assets given by him. The 1954 Code makes it clear that any such excess received for personal services is taxable compensation even though received in an otherwise taxfree exchange or distribution, e.g., where appreciated assets are exchanged for stock by controlling stockholders. ${ }^{288}$ Of course, a tax at ordinary rates reduces the benefits of capital gains on the eventual sale or redemption of the stock.

\section{Purchase of Stock for Full Value}

By its very nature, the rule taxing stock received for personal services ustrally cannot be applied when an owner-employee receives stock before he performs services for his corporation, e.g., at the time of its organization. The owneremployee builds up his eventual capital gain by contributing more to the corporation by his efforts than he withdraws as salary or dividends. The resultant appreciation in the value of his stock is his only payment for these otherwise uncompensated efforts. Nevertheless, this appreciation in value is not taxed to the owner-employee at the time he receives the stock ${ }^{280}$ because it does not then exist. 200

Similarly, no tax is imposed where stock in a new venture is sold at net asset value to employees, attorneys, and other persons connected with the busi-

288. INT. REv. CODE of 1954, §351 (a) provides that "stock or securities issued for services shall not be considered as issued in return for property" for the purpose of the generial rule permitting the tax-free exchange of property for stock or securities of a controlled corporation. This means that "stock or securities received by a person who has rendered or will render service to the transferee corporation would be fully taxable as compensation upon receipt." H.R. REP. No. 1337, 83d Cong., 2d Sess. A117 (1954). See also INT. REv. CoDE of 1954, $\$ \$ 305$ (c) (3) (stock dividends) and 356(f) (2) (corporate reorganizations and divisions). These new provisions appear to be merely declaratory of pre-1954 law. Sce, e.g., Fifth Avenue Bank of New York, 31 B.T.A. 945 (1934) (stock representing compensation for personal services taxed at ordinary rates even though received in an otherwise tax-free exchange). Cf. Philip W. McAbee, 5 T.C. 1130 (1945).

289. As a practical matter, if the owner-employee does not mention the stock in his tax return for the year in which he receives it, the statute of limitations, INT. REv. CoDE of 1939, $\S 275$ (a), (c) (3 or 5 years) ; INT. Rev. CodE of 1954, $\$$ 6501 (a),(e)(1) (A) (3 or 6 years), is likely to have run against the Commissioner by the time he learns of the transaction. In the typical case where the stock is not obviously compensation, the Commissioner probably could not sustain his burden of proving that the failure to report the stock was "with the intent to evade tax," so as to permit a later assessment for a fraudulent return. INT. Rev. CODE of 1.939, § 276 (a) ; INT. Rev. Code of 1954, § 6501 (c) (1).

290. If an executive or entertainer contracts to work for his own corporation for substantially less than his services have commanded from strangers, the stock may have taxable value at the time of receipt by reason of the contract. Bittker \& Redlich, Corporafe Liquidations and the Income Tax, 5 TAX L. REv. 437, 440-2 (1950). Cf. Altman, Tax Effects of the Sale of a Radio Show, 27 TAXEs 19, 20-21 (1949). The dearth of decisions on this point suggests that the Commissioner prefers other methods of challenging such arrangements: taxing the corporation as a personal holding company (see text at notes 5-12 supra) ; taxing the stockholder on all income received by the corporation (sce text at notcs 364-81 infra); taxing as ordinary income the stockholder's gain upon sale of the stock or liquidation of the corporation (see text at notes 485-6 infra). 
ness but not controlling it. These "non-proprietors"-201 have much the same tax advantages as the substantial owners-their gain will depend upon enhancement of the stock value attributable, more or less, to their individual efforts. ${ }^{292}$ And the benefits to non-proprietors can be multiplied if the employer helps to bring about the appreciation, especially if the employer purchases the appreciated stock. Thus the "non-proprietors" might form a new "growth" corporation which will derive much of its income from business with the employer, e.g., by serving as its sales agent. ${ }^{293}$ Except as a consequence of a possible attack by the employer's minority shareholders, ${ }^{204}$ such arrangements are not likely to be treated as compensation, at least in the absence of an understanding that the employer will later purchase the new corporation's stock.

Full value purchases of stock are not taxable as compensation, but they present the obvious difficulty that the non-proprietor may lack sufficient funds to purchase the stock. One solution to this problem is to sell non-proprietors part of a special class of high-leverage stock whose present value is low because of subordinate voting, dividend, and liquidation rights. ${ }^{295}$ As corporate earnings increase beyond the amount needed to satisfy dividend preferences, the value of this stock would increase at a rapid rate, and a sale would produce a large capital gain in relation to the small investment of the employee. A possible danger of this arrangement is that unless the two classes of stock are issued before substantial earnings have accumulated, the proprietors may be taxed as having received a dividend when they sell the new stock to the non-proprietors. ${ }^{200}$

The purchase of stock at full value by non-proprietors may also be facilitated

291. For want of a better term, "non-proprietors" will be used to denote stocliholders such as employees, attorneys, brokers, and investment bankers who perform services for the corporation but whose stock interest is relatively small compared with that of the substantial owners of the corporation.

292. E.g., Bing Crosby is reported to have paid 10 cents a share for 20,000 shares of Vacuum Foods Corp., whose product, "Minute Miaid" frozen orange juice concentrate, he was to advertise over the radio at an undisclosed salary. "Minute Maid's Mas", Time, Oct. 18, 1948, p. 91. Time fails to indicate whether the 10 cent price was less than the fair market value of the stock.

293. The Ronge and the Black, Time, May 18, 1953, p. 102, 105 (Ford Motor Company executives).

294. If the employer's minority shareholders charge a "diversion of corporate opportunity" and the management seeks to justify the arrangement as providing additional compensation, the non-proprietors may lose capital gains treatment. See note $320 \mathrm{infra}$.

295. One-class stock can be given high leverage by the issuance of bonds, debentures, or notes to the proprietors.

296. Compare Heady v. Commissioner, 162 F.2d 699 (7th Cir. 1947), zith Mlarjorie N. Dean, 10 T.C. 19 (1948) and Elmer W. Hartzell, 40 B.T.A. 492 (1939), acq., 1939-2 Cuss. BuLI. 16. Also see Commissioner v. Snite, 177 F.2d 819 (7th Cir. 1949). I:it. Rev. Cone of $1954, \S 306$, discussed in text at notes $523-5$ infra, would not be applicable if the proprietors retain the newly issued preferred stock and sell part of their old common stock. If the non-proprietors already own common stock, the proprietors will now be permitted to exchange part of their old common for new preferred in a tax-free recapitalization. Rev. Rul. 54-13, 1954 INT. REv. Burl. No. 2, at 14 (1954). 
by deferred payment plans. ${ }^{207} \mathrm{~A}$ major shortcoming of such plans is that the purchaser's obligation becomes burdensome if the value of the stock drops. ${ }^{208}$ Should the corporation then release him, the release might be taxable either as compensation or under the "foregiveness of indebtedness" theory. ${ }^{200}$ Even when the stock value increases, the non-proprietor may have difficulty meeting the deferred payments. He can sell some of his shares as each installment falls due and make the payment out of the proceeds (diminished by a capital gains $\operatorname{tax}$ ), but this would reduce his ultimate profit if the stock continued to rise. Similarly, generous dividends on the stock would be of little help to purchasers in the higher brackets, and would retard the accumulation of earnings for eventual capital gain.

Under a more elaborate deferred payment scheme the stock is purchased by an intermediate corporation owned by the non-proprietors. ${ }^{300}$ This arrange-

297. Treasury stock would ordinarily have to be used in deferred payment plans if the stock is acquired directly from the corporation because of state statutes prohibiting the issuance of stock on credit. See, e.g., N.Y. Stock CoRp. Law \&69; 13 AM. Jur., Corp. \$§ 213216 (1938).

Until quite recently, the Tax Court consistently held-and was consistently reversedthat the sale of treasury shares to employees did not result in the realization of gain (or loss) by the employer corporation. Batten, Barton, Durstine, \& Osborne, Inc., 9 T.C. 448 (1947), rev'd, 171 F.2d 474 (2d Cir. 1948) ; Rollins Burdick Hunter Co., 9 T.C. 169 (1947), rev'd, 174 F.2d 698 (7th Cir. 1949) ; H. W. Porter \& Co., 14 T.C. 307 (1950), rev'd, 187 F.2d 939 (3d Cir. 1951) ; Landers Corp., 11 T.C.M. 577 (1952), rev'd, 210 F.2d 188 (6th Cir. 1954). See also Timken-Detroit Axle Company, 21 T.C. 769 (1954), in which the Tax Court again refused to follow the appellate decisions.

On July 13, 1954 the Tax Court view was adopted by the Court of Claims in Anderson, Clayton \& Co. v. United States, 54-2 U.S. TAX Cas. f 9495 (Ct. Cl. 1954). The next day the Tax Court overruled its prior decisions and accepted the appellate court vicw. Burrus Mills, Inc., 22 T.C. No. 107 (1954). This problem is eliminated by INT. REv. CoDE of 1954, $\$ 1032$ : "No gain or loss shall be recognized to a corporation on the receipt of money or other property in exchange for stock (including treasury stock) of such corporation."

298. Although this risk can be avoided by making the taxpayer's obligation conditional, this "solution" raises additional problems. See discussion in text at notes 332-9 infra.

299. A reduction or cancellation of purchase-money indebtedness has been viewed by the courts as a mere reduction of the purchase price. Commissioner v. Sherman, 135 F.2d 68 (6th Cir. 1943) ; Helvering v. A. L. Killian Co., 128 F.2d 433 (8th Cir. 1942); Allen v. Courts, 127 F.2d 127 (5th Cir. 1942) ; Hirsch v. Commissioner, 115 F.2d 656 (7th Cir. 1940) ; Hextell v. Huston, 28 F. Supp. 521 (S.D. Iowa 1939); Charles L. Nutter, 7 T.C. 480 (1946), acq., 1946-2 CuM. Bull. 4; Ralph W. Gwinn, 3 T.C.M. 548 (1944); Gehring Publishing Co., 1 T.C. 345 (1942), acq., 1943 Cum. Bulz. 9. But these decisions have becn criticized as unjustified exceptions to the general principle that taxable income is realizcd upon a cancellation of indebtedness. Fifth Avenue-Fourteenth Street Corporation v. Commissioner, 147 F.2d 453 (2d Cir. 1945); Frank v. United States, 44 F. Supp. 729 (E.D. Pa. 1942), aff'd, 131 F.2d 864 (3d Cir. 1942). Cf. Commissioner v. Coastwise Transportation Corp., 71 F.2d 104 (1st Cir.), cert. denied, 293 U.S. 595 (1934). The Senate overruled the attempt to codify the "reduction of purchase price" theory in the 1954 House Bill, SEN. REP. No. 1622, 83d Cong., 2d Sess. 13, 14 (1954).

300 . Where the net dividend income of the intermediate corporation would be more than $\$ 25,000$ per year, the splitting of this income among two or more such corporations wottld eliminate the corporate surtax. INT. Rev. CoDE of 1939, § 15(b) ; INT. REv. CODE of 1954, $\S 11(\mathrm{c})$. 
ment takes advantage of the 85 percent intercompany dividend deduction 201 to reduce the tax rate on dividends on the newly acquired stock, enabling them to be used to pay off the deferred purchase price rapidly. ${ }^{302}$ The non-proprietors would obtain capital gains on the appreciated stock by the sale or redemption of their stock in the intermediate corporation. And incidentally, the intervening corporate entity would shield them from personal liability for the unpaid price of the stock ${ }^{303}$ and from any taxable income on a release of the obligation by the employer. However, the intermediate corporation could fall prey to the personal holding company surtax, ${ }^{304}$ and if not, to the tax on unreasonably accumulated surplus. ${ }^{305}$

To a degree, employee stock ownership can be facilitated by a "qualified" pension, profit-sharing, or stock bonus trust which invests in stock of the employer corporation. ${ }^{306}$ This would permit employees to take advantage of the statutory provisions granting capital gains on one-year severance distributions ${ }^{507}$ and postponing even the capital gains tax on that part of a distribution consisting of employer securities which have appreciated in value. ${ }^{308}$ However, the use of such trusts to promote stock ownership by key employees is limited both by uncertainty as to how much of the trust fund can be invested in the employer's stock ${ }^{309}$ and by rules against discrimination in favor of higher paid employees. 310

\section{Purchase of Stock for Less than Full Value}

The risk that the acquisition of stock by employees will be taxed as compensation is increased when the issuer is a going concern with good will rather than a

301. INT. REv. CODE of 1939, §26(b) (1) ; INT. REv. CODE OF 1954, § 243 (a).

302. See description of the "Paramount Plan" in Rudick, Income Taxes and Deferred Compensation Agreenents, 1949 U. So. Calm. Tax Inst. 163 (1949).

303. Presumably the intermediate corporation would be liable to the employer corporation for the unpaid purchase price, and the stock would be retained by the latter as collateral.

304. The personal holding company surtax could be avoided if the stock of the intermediate corporation was held by at least 10 unrelated individuals in such a way that "more than 50 per centum in value of its outstanding stock" would not be "owned, directly or indirectly, by or for not more than five individuals." INr. REv. CODE of 1939, $\$ 501$ (a) (2) ; INT. REV. CODE OF 1954, \$ 542(a) (2).

305. INT. Rev. CoDE of 1939, §102(b) ; INT. Rev. CoDE of 1954, §533(b) : "The fact that any corporation is a mere holding or investment company shall be prima facie evidence of a purpose to avoid surtax upon shareholders."

305. INT. REv. CODE of 1939, §165(a) ; INT. Rev. CODE OF 1954, \$401(a). The benefit of qualified trusts is restricted to employees as distinct from independent contractors.

307. See text at notes 13-17 supra.

308. See note 16 supra.

309. U.S. Treas. Reg. 118, §39.165-1(a) (6) (1953); P.S. 49, P-H Pens. \& Profit SHAR SERv. $\int 9547$ (1945). Query as to the applicability of these authorities to stodk bonus plans under which "benefits are distributable in stock of the employer company." U.S. Treas. Reg. 118, \$39.165-1(a) (2) (1953).

Section 505(a) (4) of H.R. 8300 (House Bill) might have permitted the investment of an unlimited percentage of the trust fund in "securities of the employer."

310. See note 79 supra. 
new venture. Because of the many variables involved in computing good will, the purchasing employee finds himself in a dilemma if the Commissioner secks to tax him on a compensatory "bargain purchase." In seeking to demonstrate that he paid fair market value for the stock, the employee may argue that capitalized past earnings should be discounted to reflect the possibility that his own death, disability, or departure might cause the loss of his services as one of the corporation's "key men"; $; 12$ this might strengthen the Commissioner's contention that the stock was transferred to him in consideration of his otherwise uncompensated services.

"Restricted Stock Options." The special treatment of "restricted stock options" 313 is the clearest exception to the rule taxing the value of stock received for services. But the exception is narrow. It covers only employees and not attorneys or other non-proprietors. And, more important, it is rarely available to employees of small corporations, both because of the ten percent stock ownership rule ${ }^{314}$ and the difficulty of ascertaining the value of the stock on the option date. ${ }^{315}$ The exclusion of small corporations from the statute conflicts with its original "incentive" rationale ; 316 "incentive" would be stronger to the employee of a small corporation, where appreciation in the value of the stock more directly reflects his efforts, than to the optionee of a large corporation, where the price rise may largely reflect stock market trends. This anomaly is partially resolved by the 1954 Code, which makes holders of more than ten percent of outstanding stock eligible for a "restricted" option if the price is at least 110 percent of the stock value on the date it is granted and if it is not exercisable after five years from that date or is exercised within one year after the enactment date of the 1954 Code. 317 This exception to the ten percent rule is intended for "stockholder-employees of closely held corporations who use stock options to retain control of their company when procuring outside equity financing." 318 But the new provision is not confined to options having this purpose, and apparently can be used to advantage whenever a sharp tise in the price of the stock is likely within a five-year period.

Other Stock Options. The law is unsettled as to what extent ordinary income is produced by a stock option which does not satisfy the "restricted stock option" provisions. The courts have frequently rejected the Commissioner's contention that the exercise of an option granted before the effective date of the

311. See Note, 53 CoL. L. Rev. 660, 700-7 (1.953).

312. See cases collected in II PaUt, Federal Estate aNd Gift Taxation $\$ 18.36$ (1942).

313. Int. Rev. Code of 1939, §130A; INT. Rev. Code of 1954, §421. See discussion of $\$ 130 \mathrm{~A}$ options and the 1954 Code's "variable price options" in text at notes 18-31 supra. (C).

314. Int. Rev. Code of 1939, §130A (d) (1) (C) ; INT. Rev. CodE of 1954, §421 (d) (1)

315. See Bergen, Restricted Stock Options for Executives of Closely Hcld Corporations, N.Y.U. 11tri Inst. on Fed. TAX. 145 (1953). But see text at note 30 supra.

316. See note 31 sipra.

317. INT. Rev. CODE of $1.954, \S 421$ (d) (1) (C).

318. H.R. Rep. No. 1337, 83d Cong., 2d Sess. 47 (1954). 
first "restricted stock option" statute gives rise to ordinary income in the amount that the value of the stock received exceeds the option price. ${ }^{310}$ These decisions are based on a finding that the parties regarded the transaction, not as "compensation," but as a means of enabling the employee to acquire a "proprietary" interest in the business, affording him a type of incentive different from his regular compensation. 320 The distinction between "compensatory" and "proprietary" options was rejected in a 1946 Treasury regulation. ${ }^{321}$ Relying on the sweeping language of the Supreme Court in Commissioner v. Smith, ${ }^{322}$ the Commissioner took the position that the bargain spread at the time of exercise should henceforth 323 be taxed as compensation, no matter how the parties regarded the transaction. The courts countered with a narrower view of the Smith case, first in cases involving options granted before the effective date of the regulation, ${ }^{384}$ and recently in several cases concerning options granted after that date. ${ }^{325}$ Sinilh is said to express no new rule of law but merely a finding of fact that the spread at the time of purchase was intended as compensation. In two of these recent cases this interpretation was used, not to exempt the transaction as "proprietary," but to limit the taxable compensation to the value of the option when received, on the ground that this was the only compensation intended by the

319. See, e.g., Rossheim v. Commissioner, 92 F.2d 247 (3d Cir. 1937) ; Norman G. Nicolson, 13 T.C. 690 (1949) ; Delbert B. Geeseman, 3S B.T.A. 258 (1938), aєq., 1939-1 CuMr. Burl. 14.

320. The risk of minority stockholder attack on "proprietary" options is reduced by recent corporate law amendments making the judgment of directors conclusive in the absence of fraud as to the adequacy of the "consideration, value or benefit, tangible or intangible, received or to be received by the corporation for the issuance of options." N.Y. STock Conp. LAw $\$ 69$, as amended by Ch. 799, Laws of 1954. See also 49 Laws of DeLaware 652 (1953). In other states the management may attempt to justify the options as providing additional compensation, thus jeopardizing capital gains treatment of the optionee. But see Tarleau, The Problem of Compensating Executives, 1953 U. So. Carrs. TAx INst. 149, 175-9 (1953).

321. U.S. Treas. Reg. 118, $\$ 39.22$ (a)-1 (c) (1953).

322. 324 U.S. 177, 181 (1945) : "Section 22(a) of the Revenue Act is broad enough to include in taxable income any economic or financial benefit conferred on the employee as compensation, whatever the form or mode by which it is effected."

323. The amended regulation was intended to apply only to options granted after February 26, 1945, the date of the Supreme Court's decision in the Smith case. See also I.T. 3795, 1946-1 CuM. BULI. 15.

324. "Proprietary" transactions were found in Norman G. Nicolson, 13 T.C. 690 (1949) ; Malcolm S. Clark, 9 T.C.M. 719 (1950); Donald R. Bradner, 11 T.C.Mr. 566 (1952), aff'd, 209 F.2d 956 (6th Cir. 1953) ; Martin L. Strauss, II, 11 T.C.M. 786 (1952), aff'd, 208 F.2d 325 (7th Cir. 1953); Abraham Rosenberg, et al., 20 T.C. No. 5 (1953); James C. Hazelton, 12 T.C.M. 398 (1953); Edward Eagan, 12 T.C.Mr. 876 (1953).

"Compensatory" transactions were found in Van Dusen v. Commissioner, 166 F.2d 647 (9th Cir. 1948), affirning, 8 T.C. 388 (1947); John C. Wahl, 19 T.C. 651 (1953); Rzy A. Noland, P-H 1953 TC MEM. DeC. \53,288 (1953); Charles E. Sorensen, 22 T.C. No. 44 (1954).

325. Estate of Lauson Stone, 210 F.2d 33 (3d Cir. 1954), affirming, 19 T.C. 872 (1953); IIcNamara v. Commissioner, 210 F.2d 505 (7th Cir. 1954), reversing, 19 T.C. 1001 (1953); Philip J. LoBue, 22 T.C. No. 58 (1954); Robert A. Bowen, 13 T.C.II. \20,471 (1954). 
parties. ${ }^{328}$ These holdings are likely to be limited to assignable options, ${ }^{327}$ but their rejection of the automatic rule of the 1946 regulation in favor of an intention test supports the Tax Court's recent findings of "proprietary" options granted after the effective date of the regulation. ${ }^{328}$

In rejecting the 1946 regulation solely on the ground that it goes beyond the Smith case, the courts have ignored several possible theoretical and practical reasons for its promulgation. Intent of the parties seems irrelevant if there has been a realized economic gain, ${ }^{329}$ and it has proved a prolific source of fruitless litigation..$^{330}$ This litigation is likely to be increased now that there are not one but three questions to be resolved: (1) Was compensation intended? (2) If so, did it arise on the option date or the exercise date? (3) If on the option date, how should the option be valued? Possibly the courts will eliminate these uncertainties by applying the rule of the 1946 regulation to options granted after the effective date of Section $130 \mathrm{~A}$ on the theory that the rule is necessary to make meaningful the detailed requirements for "restricted stock options." "131

Options to Resell. Midway between a typical stock option and an ordinary non-bargain purchase is an immediate purchase of stock at its fair market value with an option to resell to the corporation at an agreed price, usually the purchase price. 332 Such "put" options resemble the typical "call" options in that the taxpayer enjoys the benefit of any subsequent increase in value while avoiding the risk of a decline. However, "put" options are like outright purchases in

326. See the circuit court opinions in the Stone and McNamara cases, supra notc 325. This result was largely based on a dictum in the Smith opinion : "It of course does not follow that in other circumstances not here present the option itself, rather than the procecds of its exercise, could not be found to be the only intended compensation." Commissioner $v$. Smith, 324 U.S. 177, 182 (1945).

327. In the Stone case, supra note 325 , the taxpayer received negotiable warrants to purchase his employer's stock at less than its stock exchange quotation on the date of the issuance of the warrants. Having reported this spread as compensation, the taxpayer was held entitled to capital gains treatment upon the subsequent sale of the warrants. In the McNamara case, sipra note 325 , the taxpayer reported as compensation the spread on the date of receipt. The option could be assigned, was not conditioned upon the performance of subsequent services, and was characterized in corporate resolutions and reports as compensation for the year in which granted. The Stone-McNamara rule may not apply to all assignable options. See Charles E. Sorensen, 22 T.C. No. 44 (1954).

328. See the LoBue and Bowen cases, supra note 325.

329. See materials cited note 23 supra.

330. See commentaries collected by Alexander, Employee Stack Options and the 1950 Revemue Act, 6 TAx L. REv. 165, 167 n.10 (1951).

331. Id. at 202-3. Further support for this view may be found in H.R. REP. No. 1337, 83d Cong., 2d Sess. A155 (1954), stating that $\$ 421$ (e) (2) of the 1954 Code was designed to facilitate the modification of options granted after February 26,1945 to qualify them as "restricted stock options."

332. As to the possible unenforceability of such contracts by reason of state laws prohibiting corporate repurchase of stock except out of surplus, see Topken v. Schwartz, 249 N.Y. 206, 163 N.E. 735 (1928), as limited by Cross v. Beguelin, 252 N.Y. 262, 169 N.E. 378 (1929), and Greater New York Carpet House, Inc. v. Herschmann, 258 App. Div. 649, 17 N.Y.S.2d 483 (1st Dep't 1940). 
requiring an immediate investment of the individual's own funds, a disadvantage which may not be offset by the advantage of immediate dividend and other rights of full ownership. If the "put"-optionee has raised the purchase price from any source independent of the corporation, ${ }^{333}$ it seems unlikely that an otherwise nontaxable purchase of stock at current value would become taxable solely by reason of the option to resell at the same price. Theoretically, the optionee has given nothing but his services for the "put" feature and has therefore received compensation to the extent of the discounted value of the "put." However, the difficulty of ascertaining the "put" value may prevent this theory from being practiced."33

The "put"-optionee may be taxed at graduated rates when he disposes of the stock. If the value of the stock goes down and he "puts" the stock back to his employer, the Commissioner could contend that the receipt of $\$ 10$ for stock: purchased at $\$ 10$ but now worth $\$ 7$ was, in substance, a sale for $\$ 7$ coupled with compensation of $\$ 3.335$ A "put" was a short-term transaction under the "short sale" rules of Section 117(1) of the 1939 Code, which tolled the running of the holding period while the taxpayer held a "put" option. But "shortterm" treatment of the exercise of the "put" would have hurt the taxpayer only in the unusual case where the "put" price was higher than the price originally paid by him and he realized a gain by exercising the "put." In the typical case if the value of the stock goes up, the employee will not "put" the stock back at its cost but will sell the stock for its appreciated value. Although Section 117(1) (1) of the 1939 Code provided that failure to exercise a "put" was equivalent to the closing of a "short sale," the gain would apparently have been long-term if the taxpayer waited six months after his "put" lapsed before selling the stock. This question is rendered moot by the 1954 Code which provides that the "short sale" rules shall be inapplicable where the "put" is acquired on the same

333. If the corporation itself grants the credit and holds the stock as collateral, the purchase could be viewed as a "call"-type option, and the later release of the corporation's lien as the exercise of this option. Accordingly, the excess of market value of the stock on this later date over the purchase price might be taxed as compensation, unless the transaction could be analogized to a "proprietary" option.

The option to resell the newly-acquired stock at the original price would inerease its value as security for a loan from a third party.

334. Even if the taxpayer reported the purchase in his tax return (see note 289 supro), the fair market value of the "put" could not be established without expert testimony, and perhaps not even with it if the right to resell was subject to a contingency, such as death or termination of the employment. These practical difficulties are similar to those behind the Commissioner's policy not to assert a tax when an employee acquires a "call" option but to wait until the option is exercised. See, e.g., the Commissioner's position in Van Dusen v. Commissioner, 166 F.2d 647 (9th Cir. 1948), affirming, 8 T.C. 388 (1947) ; Hariey v. MCNamara, 19 T.C. 1001. (1953), rev'd, 210 F.2d 505 (7th Cir. 1954); John C. Wahl, 19 T.C. 651 (1953). Query whether the Commissioner will now invoke the Seventh Circuit rationale in McNamara to tax whatever value he can establish for assignable "put" options when received.

335. The taxpayer would have $\$ 3$ of ordinary income, only partially offset by a $\$ 3$ longterm capital loss. 
day as the stock.336 The Committee Report refers repeatedly to "purchased puts," 337 but the phraseology of the new Section 1233(c) conveniently substitutes "acquired" for "purchased" and thus seems applicable to "puts" received for services as well as for cash. ${ }^{338}$ The 1954 amendment does not affect the Commissioner's possible argument that a "spread" taxable as compensation should be measured as of the date of the expiration of the "put" option (or earlier sale of the stock to a third party) because no "risk of loss" has passed to the taxpayer before this time. This theory seems unlikely to win acceptance by the courts in view of the fact that the optionee receives the stock with dividend, voting, and all other rights of ownership when he acquires the "put."3so

Restricted Stock. It is also unclear whether taxation of stock received for services is prevented by restrictions on the alienability of the stock which reduce or eliminate its fair market value. These restrictions are ordinarily of two types: (1) an outright prohibition of sale or other transfer for a limited period of time, and (2) a requirement that the stock be resold to the corporation at a given price, commonly the original purchase price or book value at time of resale, on a given contingency, such as resignation by the employee-purchaser. Restricted stock purchased at a depressed market value carries a built-in gain which is not dependent upon appreciation in the value of the corporation. The restrictions reduce or eliminate the fair market value on which a tax would be based, ${ }^{340}$ but they may not seriously affect the inherent value of the stock to its recipient, assuming that he is able to hold the stock until after the restrictions have expired. The excess of this inherent value over the reduced or zero fair market value at time of acquisition thus escapes taxation as compensation, at least temporarily.

Restrictions were disregarded in the earliest tax decisions, ${ }^{341}$ but it is now reasonably settled that a right in the corporation to repurchase at will limits the taxable fair market value of the stock to the repurchase price ${ }^{342}$ and that a pro-

336. INT. Rev. CODE OF 1954, § 1233 (c).

337. See H.R. REp. No. 1337, 83d Cong., 2d Sess. 83 (1954).

338. The amendment is applicable only to "puts" acquired after the date of its cnactment. INT. REv. CODE of 1954, § 1233 (c).

339. Query as to an analogy between the expiration of a "put" and the expiration of restrictions on alienation, which was held not to be a taxable event in Robert Lehman, 17 T.C. 652 (1951), acq., 1952-1 CuM. Bull. 3. See text at notes 352-60 infra.

340. But see Reginald Turner, 13 T.C.M. $\llbracket 20,335$ (1954) (steamship tickets won in radio quiz program held to be worth only $\$ 1,400$ to the taxpayer although their market value was $\$ 2,200)$.

341. G \& K Mfg. Co. v. Commissioner, 76 F.2d 454 (4th Cir.), rev'd on other grounds, 296 U.S. 389 (1935) ; Rodriques v. Edwards, 40 F.2d 408 (2d Cir. 1930) ; Newman v. Commissioner, $40 \mathrm{~F} .2 \mathrm{~d} 225$, aff'd on rehearing, 41 F.2d 743 (10th Cir.), cert. denied, 282 U.S. 858 (1930) ; T. W. Henritze, 28 B.T.A. 1173 (1933). But see Wallis Tractor Co., 3 B.T.A. 981 (1926).

342. Helvering v. Salvage, 297 U.S. 106 (1935). Cf. Helen S. Delone, 6 T.C. 1188, 1193 (1946) (estate tax); Rev. Rul. 54-76, 1954 INr. Rev. Bull. No. 9, at 23 (1954) (estate tax). But see Commissioner v. McCann, 146 F.2d 385 (2d Cir. 1944) (gift tax), suggesting that value may exceed repurchase price is curcumstances indicate that the repurchase option will not be exercised. 
hibition against sale for a specified time deprives stock of all taxable value at the time of its receipt if the corporation is "highly speculative."3*3 However, uncertainty surrounds stock which is not "highly speculative" and which is subject to a prohibition against sale for a specified time or a contingent right to repurchase: Is the stock to be taxed at the time of receipt, the only effect of the restriction being to reduce its taxable fair market value? Or does taxable compensation arise when the restriction lapses, and if so, in what amount? Or does taxable compensation arise when the stock is sold, and if so, in what amount?

(1) Taxable Compensation when Stock is Received. Although several cases have refused to impose any tax upon the receipt of restricted stock of a corporation with an "untried business future,"34t the Third Circuit, in Heiner $v$ Gavinner ${ }^{345}$ pronounced the rule that restrictions reduce but do not eliminate fair market value of stock unless the corporation is "highly speculative." the Tax Court, in Harold H. Kuchman, ${ }^{347}$ ignored the Guimuer viewpoint, holding that restricted shares had no ascertainable fair market value to be included in income even though the issuer was not "highly speculative" but was merely a consolidation of five textile companies. ${ }^{348}$ Kuchman and Guimmer can perhaps be reconciled because Kuchman, unlike Gwinner, would have forfeited his stock by leaving his employment during the period of the restrictions. Or, since Kuchman involved no factual contest on the valuation issue-expert witnesses for both parties agreed that a purchaser could not be found ${ }^{340}$-the cases

343. Helvering v. Tex-Penn Oil Co., 300 U.S. 481 (1937) ; Propper v. Commissioner, 89 F.2d 617 (2d Cir. 1937) ; Morris D. Kopple, 35 B.T.A. 1056 (1937). All three cases involved enterprises which soon became insolvent.

344. Schuh Trading Co. v. Commissioner, 95 F.2d 404 (7th Cir. 1938), reecrsing, P-H 1936 BTA MEn. DEC. I 36,245 (1936) ; State Street Trust Co. v. United States, 37 F. Supp. 846 (D. Mass. 1941) ; Mac Sim Bar Paper Co., P-H 1941 BTA Afas. Dec I 41,402 (1941); Estate of Morgan J. Hammers, P-H 1943 TC Míks. DEc If 43,459 (1943). Thomas Watson, P-H 1945 TC MEAr. DeC $\{45,334$ (1945).

345. 114 F.2d 723 (3d Cir. 1940), reversing, 25 F. Supp. 659 (W.D. $P_{2}$ 1938), cert. denied, 311 U.S. 714 (1940). Cf. Fostoria Glass Co. v. Yoke, 45 F. Supp. 962 (N.D. W. Va. 1942) ; Henry S. Parker, 11 B.T.A. 1336 (1928).

346. "The restriction upon the sale or exchange of stock of course postpones the right of the owner of the stock to transfer title until the expiration of the period ... and as a practical matter results in limiting the number of prospective purchasers to those who do not desire immediate delivery .... [But] there is no reason to believe that they would have been unwilling to pay some fair price for the stock...." Heiner v. Gwinner, 114 F.2d 723, 725 (3d Cir. 1940).

347. 18 T.C. 154 (1952), acq., 1952-2 Cus. BurL. 2, discussed in Note, 62 Y YLE L.J. 832 (1953).

348. Kuchman was permitted to purchase at $\$ 5$ per share stock of his corporate cmployer which was sold publicly by the underwriters at \$25 per share. He was not permitted to sell the stock for one year without the underwriters' consent, but he could pledge it as security for a loan. If he voluntarily terminated his employment within the year, he was required to offer his stock to the underwriters at $\$ 5$ per share. The Tax Court rejected the Commissioner's contention that the $\$ 20$ spread was taxable income in the year of the purchase. Harold H. Kuchman, 18 T.C. 154, 158-9, 163 (1952).

349. The Tax Court apparently reasoned that no buyer would pay more than $\$ 5$ per share because of the restrictions, and that no seller would sell for $\$ 5$ because of the potential value of the stock and the temporary nature of the restrictions. 
may both support the rule that restrictions do not eliminate fair market value as a matter of law ${ }^{350}$ but expert testimony may prove that they reduce it to zero as a matter of fact. ${ }^{351}$ Even if restrictions do not reduce stock value to zero, they may reduce it sufficiently to eliminate a taxable "spread" in the case of purchases at substantially less than the value of unrestricted shares.

(2) Taxable Compensation when Restrictions Lapse. If reduced value caused by restrictions precludes taxation when the stock is received, it is arguable that taxable income is realized with the increased value when the restrictions expire. ${ }^{352}$ In the only case on the issue, Robert Lehman, ${ }^{363}$ the Tax Court rejected the Commissioner's contention that the expiration of restrictions produced taxable compensation to the extent of the difference between the purchase price and market value of the stock on the expiration date. ${ }^{354}$ However, the Lehman rationale does not foreclose the possibility of taxable compensation arising at the expiration date measured by the bargain spread on the purchase

350. For a contrary view, see John C. Wahl, 19 T.C. 651 (1953) and cases cited note 344 supra. See also Molloy, Restraints on Alienation and the Internal Revenue Code, 7 TAX L. REv. 439 (1952).

351. In Society Brand Clothes, Inc., 18 T.C. 304,317 (1952) it was found as a fact that stock of a listed corporation had no fair market value because subject to a 10-year option to repurchase at specified prices: "In thus making the foregoing finding of fact we do not mean to hold that as a matter of law the restriction of the sale of stock by an option necessarily destroys its fair market value." See also Spitzer v. Commissioner, 153 F.2d 967 (8th Cir. 1946) ; Worcester County Trust Co. v. Commissioner, 134 F.2d 578 (1st Cir. 1943); Kline v. Commissioner, 130 F.2d 742 (3d Cir. 1942) ; Edwin Singer, 3 T.C.M. 66 (1944) (estate tax cases). From the taxpayer's standpoint, the chief disadvantage of the question of fact rule is that it invites controversy as to the amount of the reduction in "fair market value" caused by a particular restriction. See note 355 infra.

352. Because the expiration of the restrictions is contemplated by the parties, the situation is distinguishable from Thomas W. Blake, Jr., 20 T.C. 721 (1953) (attorney held not to realize taxable income upon the removal of a cloud on title to real property received seven years earlier as a fee).

353. 17 T.C. 652 (1951), acq., 1952-1 CuM. Bull. 3; Note, 62 YALE L.J. 832 (1953). Lehman was a member of a partnership which purchased stock of two corporations pursuant to an option received for underwriting services. The partners wcre not permitted to dispose of the stock for eleven months without the consent of the vendors. Furthermore, if the vendors sold their remaining stock in the two corporations during the eleven month period, the partners were required to join in the sale for a pro rata share of the sales price, which was not to be less than the option price. Notwithstanding the bargain price, the Commissioner stipulated that taxable income did not arise in the year of the purchase because the restrictions prevented the stock from having any then ascertainable fair market value, although neither of the corporations, Kresge Dept. Stores, Inc. and The Fair, Inc., appears to have been "highly speculative."

354. "Termination of the restrictions was not a taxable event such as the receipt of compensation for services or the disposition of property. Values fluctuate from time to time and the value on a later date might be out of all proportion to the compensation involved in the original acquisition of the shares." Robert Lehman, 17 T.C. 652, 654 (1952).

The opinion states that the entire gain upon a subsequent sale of the stock was properly reported as long-term capital gain, but it does not indicate whether there was evidence of the fair market value of unrestricted shares on the purchase date, without which no allocation of the sales proceeds between capital gain and ordinary income could have been made. 
date. $^{355}$ The Commissioner may argue that, even if restrictions justify deferment of the tax, they do not justify its elimination or its conversion into a capital gains tax, especially since an employee can be said to have "earned" the termination of restrictions by his personal services. Deferred taxation of ordinary income previously realized is supported by the analogous treatment of blocked foreign currency, ${ }^{356}$ defeasible bonuses, ${ }^{357}$ and below 95 percent "restricted stock options." 358

If Lehman is construed to prohibit any taxation at the time restrictions lapse, it substantially avoids the general rule taxing stock received for personal services. In contrast with "restricted stock options," Lellman would then permit a bargain purchase by non-employees and over-ten percent stockholders at a price below 85 percent of fair market value of stock in a closely-held corporation whose stock cannot easily be valued. Moreover, because Lehman does not require that the transaction be non-compensatory ${ }^{359}$ but only that the fair market value of the stock be unascertainable, the rule could apparently be extended from purchases to bonuses of restricted stock (completely eliminating the need for financial investment by the taxpayer) $)^{360}$ and possibly to purchases or bonuses of other kinds of property with restrictions on alienation.

(3) Taxable Compensation when Stock is Sold. Lchman also leaves open the possibility that the initial spread can be taxed as compensation when the stock

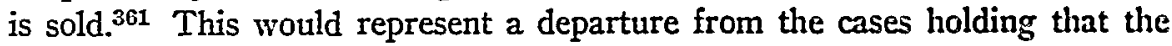
sale of stock acquired as compensation gives rise to capital gain. ${ }^{302}$ But these

355. Thus if $\$ 10$ per share were paid for stock worth $\$ 25$ when purchased (if unrestricted), $\$ 40$ when the restrictions expire, and $\$ 50$ when sold, only $\$ 15$ of taxable compensation would arise on the expiration date, as compared with $\$ 30$ under the Commissioner's contention in the Leliman case. The $\$ 15$ would be added to the cost basis of the stod: under U.S. Treas. Reg. 118, $\$ 39.22$ (a)-1(c) (1953) so that only $\$ 25$ would be long-term capital gain upon the subsequent sale.

Under the Groinner rule, see text at notes 345-51 supra, the restrictions would not prevent the imposition of tax at the time of purchase but would reduce the taxable spread. Thus if testimony showed that the restrictions reduced the fair market value on the purchase date to $\$ 15$ per share, only $\$ 5$ would be taxed as compensation.

356. Mim. 6475, 1950-1 Cun. Burl. 50.

357. Fred C. Hall, 15 T.C. 195 (1950); Phillip W. Haberman, 31 B.T.A. 75 (1934), aff'd, 79 F.2d 995 (2d Cir. 1935) ; Boscoe H. Aldrich, 3 B.T.A. 911 (1926).

358. Int. Rev. CoDE of 1939, \$130A (b) ; INT. Rev. CODE of 1954, \$421 (b). Another possible precedent is Arrowsmith v. Commissioner, 344 U.S. 6, 8-9 (1952) (stockholders of dissolved corporation realized only capital loss from payment by them of judgment against corporation several years after last liquidating distribution reported as capital gain): "But this principle [that each taxable year is a separate unit] is not breached by considering all the 1937-1944 liquidation transaction events in order properly to classify the nature of the 1944 loss for tax purposes."

359. As the Kuchmman case indicates, the restricted stock theory can be coupled with the "proprietary" theory in opposing the taxation of the bargain spread.

360. But see cases cited note 357 supra.

361. But see note 354 supra.

362. Commissioner v. Timmer, 78 F.2d 599 (6th Cir. 1935). Cf. Carl MrcFarlin, 1 T.C.M. 703 (1943). For the tax consequences of a sale of stock received as compensation but not reported in the year of receipt, see Mintz \& Plumb, Taxing Inconse in Ycars Not 
decisions apparently presume that the stock was taxable on receipt and thus may turn on the theory that the retention and sale of the stock constitute an investment transaction separate and distinct from the compensatory transaction by which the stock was acquired. Hence it is arguable that their rule should not be extended to restricted stock cases where the compensation element would escape ordinary tax rates. A tax on compensation at the time the stock is sold would still leave restricted stock purchases with the advantages of an indefinite deferment of tax, and possible avoidance of tax if the stock is held until the purchaser's death. ${ }^{363}$

\section{Preventing Attribution of Corporate Income to the Stockholder-Employec}

Capital gains through the accumulation of corporate income are aborted if the income is attributed to the principal stockholders in their indiviclual capacities. This danger is minor for the owner of an enterprise employing substantial capital as well as his personal services, but it may become real as the importance of capital diminishes in relation to that of services. In the case of a one-man advertising or brokerage business, for example, the only apparent factual difference between the corporation and a sole proprietorship is the "Inc." on the door.

Tax law abounds with concepts which might be invoked by the Commissioner to tax corporate income as belonging directly to the stockholder-employee. ${ }^{301}$ Unfortunately, these concepts have little predictive value. A few cases permit the Commissioner to disregard the corporate entity, but they afford only vague tests as to when he may properly do so. ${ }^{365}$ The Code authorizes him to reallocate gross income and deductions where necessary "to prevent evasion of taxes or clearly to reflect the income" of related taxpayers, but it gives little indi-

Realized under Doctrine of Equitable Estoppel, 1954 U. So. Calif. Tax Inst. 481, 542 (1954).

363. Query whether the compensation element would be ordinary income upon a sale of the stock by the taxpayer's executor under INT. REv. CoDE of 1939, §126(a) (3) ; INr. Rev. CODE of 1954, $\$ 691$ (a) (3). Presumably any amount taxed as compensation would be added to the executor's stepped-up basis under INT. REv. CodE of 1939, § 113(a) (5); INr. REv. CODE OF 1954, $\$ 1014$, and thus cause a concurrent capital loss.

364. The Commissioner may have relied upon INT. REv. CoDE of 1939, § 102 to limit the avoidance of graduated rates, but he is less likely to do so in the future because of the softening of the penalty tax on improperly accumulated surplus by INT. REv. CODE of 1954, §§ 531537. See text at notes $383-93$ infra.

365. "The Government may look at actualities and upon determination that the form employed for doing business or carrying out the challenged tax event is unreal or a sham may sustain or disregard the effect of the fiction as best serves the purpose of the tax statute." Higgins v. Smith, 308 U.S. 473, 477 (1940). The corporate entity was disregarded in Commissioner v. Smith, 136 F.2d 556 (2d Cir. 1943); Paymer v. Commissioner, 150 F.2d 334 (2d Cir. 1945) ; Advance Machinery Exchange, Inc., 8 T.C.M. 84 (1949), aff'd, 196 F.2d 1006 (2d Cir.), cert. dentied, 344 U.S. 835 (1952). But see Moline Properties, Inc. v. Commissioner, 319 U.S. 436 (1943) : "So long as that purpose is the equivalent of business activity or is followed by the carrying on of business by the corporation, the corporation remains a separate taxable entity." See Cleary, The Corporate Entity In Tast Cases, 1 TAX L. REv. 3 (1945). 
cation when the rendition of services by a stockholder-employee would involve "evasion" or an unclear reflection of income. ${ }^{360}$ Judicial rules permit the Commissioner to disregard: a transaction whereby compensation is prevented "from vesting even for a second in the man who earned it" (Lucas $v$. Earl ${ }^{367}$ ); a transaction lacking a business purpose (Gregory v. Hclvering ${ }^{368}$ ); and a transaction between a wholly-owned corporation and its owner which produces no change in economic position (Higgins $v$. Smith ${ }^{302}$ ). These concepts differ in emphasis, but each merely restates the question: Is income earned by the corporation or its sole owner?

Tentative and partial answers to this question may be inferred from the few decisions taxing corporate income to a controlling stockholder. In Commissioncr $v$. Laughton, ${ }^{370}$ the British movie actor had entered into a five-year employment contract with his wholly-owned corporation at a salary very much less than the corporation received for the "loan" of his services. The Ninth Circuit held that the presence of "business purposes"371 did not preclude disregarding the corporate entity under the rule of Higgins $v$. Smith. It remanded the case to determine as a fact whether the arrangement was in effect a single transaction in which Laughton indirectly received the amount paid for his services. ${ }^{372}$ On remand Laughton consented to the assessment of deficiencies against him..$^{373}$ The same result was reached in Clinton Davidson ${ }^{374}$ concerning a life insurance agent who contracted to turn over commissions on subsequently written policies to his wholly-owned Estate Planning Corporation in return for a salary, which in fact he never received. Under New York law the corporation could not te licensed as an insurance agent, ${ }^{375}$ but it did serve several business purposes, including the employment of a staff and extensive advertising of the "Estate

366. INT. Rev. CoDE of 1939, § 45; INT. Rev. Code of 1954, §482. As used in $\S 45$, the word "evasion" has been construed to mean profit-shifting rather than fraud. Asiatic Petroleum Co. v. Commissioner, 79 F.2d 234 (2d Cir.), cert. deried, 296 U.S. 645 (1935).

367. 281 U.S. 111, 114-5 (1930). See note 99 supro.

368. 293 U.S. 465 (1935), affirming, 69 F.2d 809 (2d Cir. 1934). See Mfichaclson, "Business Purpose" and Tax-Free Reorganization, 61 YaLE L.J. 14 (1952).

369. 308 U.S. 473 (1940) (jury properly instructed to find whether sale to taxpayer's wholly-owned corporation was transfer from his individual hand to his corporate hand, so that it was no transfer at all).

370. 113 F.2d 103 (9th Cir. 1940).

371. The Board of Tax Appeals had found two non-tax purposes: to accumulate funds for the production of superior films by the corporation; to entrust the conservation of Laughton's earnings to a board of directors consisting of independent businessmen. Charles Laughton, 40 B.T.A. 101 (1939). The B.T.A. decision was in accord with its carlier ruling in Fontaine Fox, 37 B.T.A. 271 (1938).

372. Commissioner v. Laughton, 113 F.2d 103, 104 (9th Cir. 1940). Although the taxable years involved were prior to the effective date of the 1937 amendment to the personal holding company statute, notes 8-12 supra, neither the Board nor the Ninth Circuit believed that the statutory remedy precluded a "common law" solution.

373. See Bittker \& Redlich, Corporate Liquidations and the Income Tax, 5 TAX L. REv. 437, 444 (1950).

374. 43 B.T.A. 576 (1941).

375. N.Y. INs. LAw $§ 91$. 
Planning" name. The Board of Tax Appeals held that the commissions had been earned by the taxpayer in his individual capacity, but permitted him to deduct all expenses paid by the corporation.

The Laughton and Davidson decisions may mean only that a controlling stockholder-employee is taxed on corporate income when the services could not be performed by another person or when the corporation could not legally perform the services itself. Or these cases may mean that he is taxed whenever he does not receive compensation from the corporation comparable to that which he formerly received from third parties. But even if these cases are viewed as reallocations of gross income between related taxpayers to restate their incomes on an arm's-length basis, ${ }^{376}$ their rationale is not easily applied to most one-man corporations. In the ordinary case the Commissioner would find it far more difficult than in Langhton and Davidson to establish the fact-and dollar value -of uncompensated services, ${ }^{377}$ e.g., where the corporation has non-clerical employees or substantial capital. ${ }^{378}$ Moreover, a distinction might be macle between compensation for personal services and entrepreneurial profit, so that the latter is taxed to the corporation even though partially attributable to the services of the owner-employee. ${ }^{370}$

An employee-stockholder will rarely be taxed on what purports to be corporate income, if he is careful that the income does purport to be that of the corporation. But if he contracts in his individual capacity rather than as the corporation's representative, he may be taxed on the resultant income on the theory that it has merely been assigned to the corporation and not earned by it. ${ }^{380}$ Similarly, the corporation must not appear dormant by failure to hold meetings, keep minutes, and maintain separate corporate financial records and bank accounts. ${ }^{381}$

376. U.S. Treas. Reg. 118, $\S \$ 39.45-1$ (a) (6), (b) (1) (1953). See Bittker \& Redlich, supra note 373 , at 447 suggesting that the corporate entity should not insulate underpaid stockholder-employees from tax on corporate income: "The reason they serve without compensation is to reduce their taxes, and this reason may condemn the scheme."

377. On this issue the contentions of both Commissioner and taxpayer would be diametrically opposite to their usual contentions in cases involving the deductibility of "reasonable" compensation under INT. REv. CODE of 1939, § 23 (a) (1) (A) ; INT. Rev. Code of 1954, $\S 162(a)(1)$.

378. An allocation of this type is required where services are performed by the donor of an interest in a family partnership. INT. REv. CODE of 1939, § 191; INT. REv. CODE of $1954, \S 704$ (e) (2). See discussion in Weiss v. Johnson, 206 F.2d 350 (2d Cir. 1953).

379. In the Davidson case the taxpayer entered into a new contract with the Estate Planning Corporation whereby he retained subsequent commissions and paid the corporation ten percent thereof plus its expenses. Davidson was permitted to deduct, and the corporation was taxed upon, the profit element attributable to the estate planning services as distinct from the routine insurance agency services.

380. Brown v. Commissioner, 115 F.2d 337 (2d Cir. 1940) (stockholder taxed on compensation for services performed as individual despite assignment to wholly-owned corporation). Cf. Thompson v. United States, 110 F.2d 585 (5th Cir. 1940).

381. See, e.g., Paymer v. Commissioner, 150 F.2d 334 (2d Cir. 1945); Advance Machinery Exchange, Inc., 8 T.C.M. 84 (1949), aff'd, 196 F.2d 1006 (2d Cir.), ccrt. denied, 344 U.S. 835 (1952). 


\section{Minimizing Corporate Taxes}

Accumulation of income within a corporation followed by sale or redemption of the stock is advantageous primarily if the sum of corporate taxes and capital gains tax is less than the graduated personal income tax that would be incurred if the business were conducted as a sole proprietorship or partnership. Corporate taxes include the rarely applicable surtax on personal holding companies, 352 the surtax on corporations improperly accumulating surplus, the recent excess profits tax, and the regular corporate income tax.

\section{Surtax on Improperly Accumulated Surplus}

The penalty surtax on corporations improperly accumulating surplus ${ }^{383}$ has been a major obstacle to the use of corporations to convert the fruits of personal effort into capital gain. Although accumulation is permitted for "the reasonable needs of the business," 384 these needs are usually small in the case of a personal service enterprise. Such a corporation may, nevertheless, be able to show a "reasonable need" to expand its activities into related fields requiring considerable capital, ${ }^{385}$ to purchase a building to house its activities, to hedge against contingent liabilities and anticipated economic adversities, ${ }^{380}$ and possibly to insure the lives of key men. ${ }^{387}$

Prior to the 1954 Code, if the owner of a small business were in the upper brackets, tax rate arithmetic sometimes recommended use of the corporate form even though the penalty tax might be incurred. The penalty tax was $271 / 2$ percent on the first $\$ 100,000^{388}$ of undistributed corporate income after certain adjustments, particularly the subtraction of the regular corporate income tax. The latter tax was 30 percent on the first $\$ 25,000$ and 52 percent on the balance. ${ }^{389}$ Even if the combination of these two taxes and the even-

382. Discussed in text at notes 5-12 supra. See General Management Corporation v. Commissioner, 135 F.2d 882 (7th Cir.), cert. denied, 320 U.S. 757 (1943) (surtax imposed). Rev. Rul. 54-34, 1954 INT. Rev. Bulz. No. 4, at 7 (1954).

383. Int. Rev. Code of 1939, § 102; INT. Rev. CODE of 1954, \$§ 531-537.

384. INT. Rev. Code of 1939, § 102(c) ; INT. Rev. Cone OF 1954, \$\$ $533(\mathrm{a}), 537$.

385. Fisher and Fisher, Inc, 32 B.T.A. 211 (1935) ( $\$ 102$ inapplicable to a corporation formed by cartoonist to furnish drawings to cartoon syndicate because corporation contemplated acquiring its own distribution facilities, purchasing interest in a newspaper, and producing cartoon films). But cf. Reynard Corp., 37 B.T.A. 552 (1938) ( 102 applied to corporation organized by cartoonist for similar purposes). See also Fontaine Fox, 37 B.T.A. 271 (1938).

386. INT. REv. CODE OF 1954, \$ 537 expressly provides that the "reasonable needs of the business" include "reasonably anticipated needs." For a typical pre-1954 case see Belaire Management Corp., 21.T.C. 881 (1954) ( $\$ 102$ applicable despite taxp3yer's contentions concerning various contingencies).

387. Cf. Emeloid Co. v. Commissioner, 189 F.2d 230 (3d Cir. 1951) (indebtedness incurred to insure life of key man held to be "incurred for business reasons" and includible in "borrowed invested capital" for excess profits tax purposes).

388. Int. Rev. Code of 1939, §102(a); INT. Rev. CoDe of 1954, § 531. The rate is $38 \mathrm{~s} / 2$ percent on amounts over $\$ 100,000$.

389. Int. Rev. Code of 1939, $\$ 13$ (b) (2), 15(b) ; INT. Rev. Code of 1954, $\S \S 11$ (b) (1), 11 (c). The 30 percent normal tax is now scheduled to drop to 25 percent effective April 1 , 1955. Id. $§ 11(\mathrm{~b})(2)$. 
tual capital gains tax was more than the owner would pay as a sole proprietor or partner, the Commissioner's apparent readiness to settle for less than the full penalty tax often made incorporation a good gamble.

This gamble is made much more attractive by the 1954 Code. The new statute permits the taxpayer to shift the burden of proving unreasonableness to the Commissioner. ${ }^{390}$ It taxes only that part of the current accumulation found to be in excess of the reasonable needs of the business. ${ }^{301}$ And it permits a corporation accumulate up to $\$ 60,000$ irrespective of its needs ${ }^{302}$-an important advantage for most personal service corporations. The 1954 Code does seek to curb multiplication of the $\$ 60,000$ credit by the formation of several corporations out of an existing corporation, but it allows a credit to each new corporation which is a continuation of an unincorporated business or receives only "money" from an existing corporation. ${ }^{303}$

\section{Excess Profits Tax}

Unlike the unpredictable incidence of the accumulated earnings tax, the excess profits tax automatically applied to all corporations for the years 1940 through 1945 and from July 1, 1950 to the end of 1953. Both the World War II and the Korean versions of the tax exempted "personal service corporations," if the stockholders included in their personal income pro rata shares of undistributed corporate profits. ${ }^{304}$ Obviously this election cancelled out the principal tax advantage of cloing business as a corporation. If no election was made, the corporation was subject to a 30 percent tax on its income, after certain adjustments and after subtracting a credit representing normal earnings. 305 The "invested capital" methods of computing this credit were of little help to personal service corporations with small capital. ${ }^{306}$ Even the credit

390. Int. Rev. CODE of 1954, § 534. The new procedure is described in SEN. Rep. No. 1622, 83d Cong., 2 d Sess. 315 (1.954).

391. INT. REv. CODE of 1954, $\$ 535$ (a), (c) (1), (2). If any part of the accumulation was found unreasonable, the 1939 Code taxed the entire accumulation. The benefit of the new rule is denied to a "mere holding or investment company." $I d$. $\$ \$ 535$ (c) (1), (3).

392. Id. $\$ 535$ (c) (2). The $\$ 60,000$ minimum credit is reduced (possibly to zero) by the accumulated profits at the close of the preceding taxable year.

393. Id. §1551. A new personal service corporation might be held to have acquired "property" in the form of the good will of an old corporation.

This section is almost identical with INT. REv. CoDE of 1939, $\$ 15$ (c) which disallowed both the $\$ 25,000$ minimum excess profits credit and the $\$ 25,000$ surtax exemption to a corporation acquiring property from another unless the corporation could "establish by the clear preponderance of the evidence that the securing of such exemption or credit was not a major purpose" of the acquisition.

394. The Korean law, INT. REv. CodE of 1939, §449, was identical with the World War II law, INT. REv. Code of 1939, $\$ 725$, which in turn was based upon Revenue Act of 1918, $\S 200,40$ Stat. 1058 (1918), and Revenue Act of 1921, \$ 500(5), 42 STAT. 2281 (1921). Sce Gutkin, Section 725: Personal Service Corporations, 3 TAX L. Rev. 89 (1947).

395. Int. REv. CoDE of 1939, $\$ 430$ (a) (1), 433(a). This and all succeeding excess profits tax references are to the Korean statute.

396. Id. $\$ \S 437,458$. 
based on modified average earnings during four "base period" years 397 and the various "relief" provisions ${ }^{398}$ did not make it profitable for new or growing personal service enterprises to operate as corporations, unless their income was less than the $\$ 25,000$ minimum credit ${ }^{309}$ or their activities could be divided among several corporations each with an income under $\$ 25,000$. Section 15 (c), enacted in 1951 to disallow multiple credits, could probably have been avoided by most personal service businesses. ${ }^{400}$

\section{Corporate Income Tax}

Any one of the special corporate taxes may be the decisive factor in a particular case, but in almost every case the regular corporate income tax must be added to the capital gains tax in weighing the feasibility of incorporation. During recent years individual rates have fallen from their World War II peak, largely through the introduction of marital income-splitting, while the corporate normal tax rate has risen to 30 percent with a corporate surtax of 22 percent. ${ }^{401}$ Accordingly, successful use of the corporate form to obtain capital gains is largely dependent upon the reduction or elimination of the corporate income $\operatorname{tax}$.

Multiple Corporations. To avoid the 22 percent surtax on income in excess of $\$ 25,000$, a taxpayer may divide his business into several corporations. ${ }^{402}$ In doing so he runs the risk that the Commissioner will be able to reallocate the income to one corporation or to the stockholders as individuals. ${ }^{403}$ Generally, this risk is negligible if each corporation maintains separate financial records and bank accounts and deals with the others at arms-length terms, and if the division of business functions among the several corporations can be justified on non-tax grounds. For example, a commission agency might safely employ separate corporations for different lines of products, classes of customers, geographical areas, or for the segregation of commission activities from trading activities. $^{404}$

397. Id. $\$ 435$.

398. Alternate credits, e.g., id. $\$ 445$, were ordinarily useless to personal service corporstions because based on net assets. Similarly, the 18 percent ceiling rate, id. $\S 430$ (a) (2) (C), based on income without any credit, was beneficial only if income were at least $21 / 2$ times the available credit, e.g., a small corporation with only the $\$ 25,000$ minimum eredit derived no benefit from the 18 percent rate unless its income exceeded $\$ 62,500$. As to the low:cr alternate rates for "new corporations," id. $\$ 430$ (e), see Miller, Excess Profits Tax Consequerices of Acquiring Partnership or Proprietorship Assets, N.Y.U. 11тH Isst. ON FED. TAx. 973, 990-3 (1953).

399. INT. REv. CODE OF 1939, § 431.

400. See note 393 supra and corresponding text.

401. See note 389 supra.

402. But if obtaining the surtax exemption is a major purpose of the transaction, the exemption may be denied. INT. Rev. Code of 1939, \& 15(c); INT. Rev. Cone OF 1954, § 1551. See note 393 supra.

403. See text at notes $365-9$ sipra.

404. See Cooper, Section 45, 4 TAX L. REv. 131 (1949). Other possible non-tax grounds for division would include the segregation of hazardous activities, the reduction of state franchise taxes, and the facilitation of employee stock ownership. 
Loss Corporations. While multiple corporations reduce the corporate tax, use of a "loss" corporation may eliminate it completely. The taxpayer purchases at a low price the stock of an old corporation with few assets but with a history of substantial operating losses which can be carried forward to offset corporate profits for up to five years. ${ }^{405} \mathrm{He}$ next transfers operating assets to the corporation through a sale, a contribution to capital, or a merger of another corporation into the loss corporation. He then conducts his business within the old corporate shell. Frequently, both the nature of the business and the name of the old corporation are changed, so that all that remains is a legal fiction-and potential tax savings from the loss carry-overs. Although most "loss" corporation devices seem to come within both letter" and spirit of the old Section $129,{ }^{406}$ the Commissioner has yet to win a single case under that section largely because of inability to prove that tax avoidance was the "principal purpose" of the acquisition. ${ }^{407}$ And the Tax Court has intimated that, regardless of the taxpayer's purpose, the "section would seem to prohibit the use of a deduction, credit, or allowance only by the acquiring person or corporation and not their use by the corporation whose control was acquired." 409

To meet this "serious tax-avoidance problem," 400 Section 269 of the 1954 Code augments the old Section 129 with a mild presumption that tax avoidance is the "principal purpose" of the acquisition if the consideration paid for stock of the old corporation substantially exceeds the sum of the tax basis of its assets and any other tax benefits made available by the acquisition. ${ }^{410}$ And the new Section 382 disallows the carry-over of operating losses if fifty percent or more of a corporation's stock ${ }^{411}$ changes ownership ${ }^{412}$ during a two-year

405. In addition to operating loss carry-overs under INT. Rev. CoDE of 1939, §122; INT. REv. CODE of $1954, \S 172$, the acquiring corporation may be entitled to a capital loss carry-over under INT. REv. CODE of 1939, §117(e) ; INT. Rev. Code of 1954, \$1212 and unused excess profits credit carry-overs under INT. REv. CoDE of 1939, $\$ 432$.

406. Int. Rev. CoDe of 1939, § 129 ; INT. Rev. Code of 1954, § 269. Deductions, credits and allowances are prohibited where control of a corporation has been acquired, or property has been acquired by one corporation from another with a substituted basis, for the "principal purpose" of avoiding income or excess profits tax. See Tarleau, Acquisition of Loss Companies, 31 TAXES 1050 (1.953).

407. However, in Alpha Tank \& Sheet Metal Mfg. Co. v. United States, 116 F. Supp. 721 (Ct. Cl. 1953) both $\S 129$ and $\$ 45$ were cited as authority for a decision in the Commissioner's favor.

408. Alprosa Watch Corporation, 11 T.C. 240, 245 (1948). See also A. B. \& Container Corporation, 14 T.C. 842 (1950).

409. SEN. Rep. No. 1622, 83d Cong., 2d Sess. 39 (1954).

410. INT. REv. CoDE of 1954, $\$ 269$ (c). The House Bill would have reçuired the taxpayer to overcome this presumption "by a clear preponderance of the evidence," but a Senate amendment makes a substantially excessive price merely "prima facie evidence" of a purpose to avoid tax-as it probably was treated under prior law. This nullifying amendment was said to be necessary to afford the taxpayer "the opportunity of proving that tax avoidance was not the principal purpose." SEN. REP. No. 1622, 83d Cong., 2d Sess. 39 (1954).

411. For this purpose, "stock" is defined as "all shares except nonvoting stock which is limited and preferred as to dividends." INT. REv. CoDE of 1954, \$382(c).

412. Id. $\S 382$. A person is deemed to own stock held by relatives and by corporations, 
period as the result of stock purchases $\$ 13$ or redemptions ${ }^{114}$ and the corporation materially changes its trade or business. $\mathbf{4 1 5}$

Yet, by another provision, the 1954 Code produces new opportunities to deduct other people's losses. The Supreme Court has held that when a corporation with operating losses transfers substantially all its assets to another corporation in a tax-free reorganization, the transferee is not entitled to offset subsequent profits by carrying forward the losses of the transferor. ${ }^{210}$ By overruling this decision, 417 the new statute makes it possible for the purchasers of a loss corporation to enjoy its loss carry-overs without having to keep it alive or to transfer their profitable activities to it. As an alleged safeguard against abuse, the carry-overs are cut down pro rata if the stockholders of the loss corporation receive less than twenty percent of the stock of the transferee corporation for their old stock. ${ }^{418}$ Thus if carryovers are large enough to permit the shareholders of a loss corporation to demand twenty percent of the purchaser's stock in payment, the carry-overs may be used in full by the purchaser, barring the still remote possiblity that the Commissioner can prove that tax avoidance was the "principal purpose" of the transaction.110

Collapsible Corporations: Distribution before Rcalization. The collapsible corporation, ${ }^{420}$ a device indigenous to the personal service area, also seels complete elimination of the corporate income tax. The accomplishment of two

partnerships, and trusts to the extent of his interest therein. Id $\$ 382$ (a) (1) (B) (i), (ii), 382 (a) (3).

413. Under $i d . \$ 382$ (a) (4), an increase in stock ownership is treated as a "purchase" only if the basis of the stock is determined "solely" by reference to its cost to the holder and if the stock has been acquired from someone whose ownership of the stock would not be attributed to the holder under the constructive ownership rules.

414. Except redemptions under $\$ 303$ to pay death taxes. Id. $\$ 382$ (a) (1) (B) (ii).

415. SeN. Rep. No. 1622, 83d Cong., 2d Sess. 285 (1954), states that a change in business is material "if, as a result of [the change in ownership of stock] the corporation shifts from one type of business to another, ... changes its location, or otherwise fails to carry on substantially the same trade or business as was conducted before such an increase in stoct: ownership." (Emphasis added.) The "result" requirement does not appear in the statute. Any action taken by a new management could be said to "result" from the change in ownership, but this might not be true where the action was in response to external economic factors. The Conference Report states: "If the corporation continued to carry on substantially the same trade or business, the limitation would not be applicable even though the corporation also added a new trade or business." H.R. REP. No. 2543, 83d Cong., 2d Sess. 40 (1954).

416. New Colonial Ice Co. v. Helvering, 292 U.S. 435 (1934).

417. INT. REv. CODE of 1954, \$\$ 381 (a), (c) (1).

418. INT. Rev. CoDe of 1954, $\$ 382$ (b) (1), (2). The 20 percent limitation does not apply if both corporations are owned substantially by the same persons in the same proportion. Id. $\$ 382(\mathrm{~b})(3)$.

419. According to SEN. REP. No. 1622, 83d Cong., 2d Sess. 285 (1954), §269 may apply if $\S 382$ does not apply but can never apply if $\S 382$ does apply. This suggests that where there is a substantial risk that $\$ 269$ will deny the entire carry-over, the stockholders of the loss corporation may be given a small percentage of the stock of the reorganized corporation insuring the allowance of five times that percentage of the carry-over.

420. For a brief description of the collapsible corporation device and the 1950 amendment see text at notes 59-67 supra. 
objectives is required : First, the stockholders must be taxed only at capital gain rates upon the income generated by the corporation's productive activities. Second, the corporation must be insulated from any tax on this income by its distribution to the stockholders of the property produced by the corporation or of claims to income from that property. If these objectives are not attained, the collapsible corporation may result in heavier taxation than the more typical corporation which realizes, and is taxed on, the income from its activities before liquidation or sale of its stock.

(1) Tax Treatment of Stockholders. The heart of the collapsible corporation scheme is the avoidance of corporate tax; yet the statutory attack of Section $117(\mathrm{~m})^{421}$ is not directed at the corporation but at the stockholder by denying him capital gains. And this attack can seldom be launched. The corporation must be used "principally" to produce or purchase "property" "with a view to" liquidation ${ }^{422}$ before the corporation realizes a "substantial" part of the income to be "derived" from such property. The definition of a collapsible corporation involves many uncertainties which have yet to be considered by the courts. ${ }^{423}$ For instance, there is confusion about whether the statute applies to a "multiple shot" corporation which has realized and paid tax on "stibstantial" income from some activities but not on potential income from others at the time of the sale, liquidation or distribution. ${ }^{424}$ The Regulations seek to apply the statutory tests to each activity separately, ${ }^{425}$ but the courts may take the less sophisticated view that the corporation has not been used "principally" with a view to tax avoidance.

Even if their corporation fits the definition of a "collapsible corporation," the stockholders may escape taxation at ordinary rates under one of several statutory or administrative "limitations." 426 The statute is applicable only if more than seventy percent of the stockholder's recognized gain is attributable to the property produced by the corporation with the proscribed intent. ${ }^{427}$ This ambiguous test may possibly permit the stockholders to circumvent the statute by contributing enough low-basis assets to the corporation to prodtce

421. INT. Rev. Code of 1939, §117(m); INT. Rev. Code of 1954, §341 (b).

422. Or other corporate distribution, or a sale of the stock. Ibid.

423. See MacLean, Collapsible Corporations-The Statute and Regulations, 67 Hunv. L. REv. 55, 74 (1953): "In unusual cases, a question might be raised whether certain items having value, such as good will, unpaid claims for services, and contract rights, would come within the section. Probably the term 'property' should be held to apply to such items."

424. See Walker, Investing in Motion Picture Enterprises, 1954 U. So. CALIF. TAx INST. 399, 406 et seq. (1954).

425. U.S. Treas. Reg. 118, $\$ 39.117$ (m)-1 (e), Examples 2 and 5 (1953). Sce MacLean, supra note 423 , at $70-4$.

426. The first of these limitations, rendering the statute inapplicable to under ten percent stockholders (five percent under the 1954 Code) would seldom be of much help to the typical personal service venture. INT. REv. CodE of 1939, $\$ 117$ (m) (3) (A) ; INT. REv. Cove of 1954, \& 341.

427. Int. Rev. Code of 1939, $\S 117$ (m) (3) (B) ; Int. Rev. Code of 1954, $\$ 341$ (d) (2). 
thirty percent of their subsequent gain. 28 Or the three-year limitation 429 might conceivably permit avoidance by a sale of the stock for a down payment not greater than the stockholder's cost basis with the balance payable under an unsecured contract after the three years. ${ }^{430}$ Or, since the statute apparently applies only to "recognized" gains, ${ }^{431}$ the stock can apparently be disposed of in a non-taxable reorganization, ${ }^{432}$ followed at a discreet interval by a sale of the stock received in the reorganization.

The courts have yet to decide whether a stockholder who does not come within the collapsible corporation statute may nevertheless be taxed at graduated rates under "common law" theories. ${ }^{\text {} 34}$ The Commissioner unsuccessfully attempted to invoke some of these in a pre-117(m) case, Herbcrl v. Ridd cll. ${ }^{435}$

428. See MacLean, supra note 423, at 78-80. Perhaps this would be successful only where the assets contributed are actually used (or potentially useful) in the corporation's productive activities. Query as to the applicability of $\$ 129$ of the 1939 Code ( $\$ 269$ of the 1954 Code)?

429. Int. Rev. CODE of 1939, §117 (m) (3) (C) ; INT. Rev. Code of 1954, §341 (d) (3): "[T]his subsection shall not apply to gain realized after the expiration of three years following the completion of such manufacture, construction, production, or purchase."

430. The theory would be that the unpaid balance is not part of the "amount realized" and hence not part of the "gain realized" by a cash-basis seller in the year of sale. I:xT. REv. CoDe of 1939, §111; INT. Rev. CoDE of 1954, § 1001. Nina J. Ennis, 17 T.C. 465 (1951); Harold W. Johnston, 14 T.C. 560 (1950). Cf. Levin \& Mfitosky, Tax Sazing Praclices of Artists and Entertainers, 31 TAXEs 21, 30 (1953). But see MacLean, supro note 423, at $81-2$.

431. U.S. Treas. Reg. 118, §39.117(m)-1(C) (1) (1953).

432. For example, the owners of a single-venture movie corporation could exchange their stock or the completed movie for stock in a large established movie producer. INT. REv. CODE of 1939, $\$ \S 112$ (b) (3), (4), and (g) (1) (B), (C) ; INT. Rev. Code of 1954, $\$ \$ 354$ (a) (1), 368(a) (1) (B), (C). This scheme probably would not work if the acquiring corporation were controlled by the stockholders of the collapsible corporation or were not large enough to avoid becoming itself a collapsible corporation. INт. REv. CoDE of 1939, $\$ \S 117$ (m) (2) (A), (B) (ii) ; INT. Rev. CODE OF 1954, $\$ 3341$ (b) (1), (2) (B).

433. A less satisfactory means of avoiding the collapsible corporation statute was through non-recognition of gain in an elective one-month liquidation. INT. REv. CODE of $1939, \S 112$ (b) (7). The Commissioner ruled $\S 117(\mathrm{~m})$ inapplicable to that portion of a taxpayer's liquidation gain which was not "recognized" under $\$ 112(b)$ (7). RIA FED. TAx. COORDINATOR, II E-1,731c (1953). Because of the usual low basis under $\$ 113(a)$ (18) of assets thus acquired, the stockholders avoided graduated rates only if the assets qualified as capital assets in their hands and were disposed of in a later sale or exchange. Cf. Osenbach v. Commissioner, 198 F.2d 235 (4th Cir. 1952). INr. Rev. Code of 1954, §333(1) denies the one-month liquidàtion election to stockholders of collapsible corporations.

434. SEN. ReP. No. 2375, 81st Cong., 2d Sess. 88 (1950), states that $\$ 117(\mathrm{~m})$ applies "only to the extent that the use of the [collapsible corporation] device is interpreted as giving rise to gain, which gain is considered (but for the provisions of the subsection) as long-term capital gain." See Bittker \& Redlich, Corforate Liquidalions and the Income Tax, 5 TAX L. Rev. 437, 437-48 (1950); De Wind, Collapsible Corporations under the Rvemue Act of 1950, 1951 U. So. Caltr. Tax Inst. 583, $591-2$ (1951). Cf. S. Nicholas Jacobs, 21 T.C. 165 (1953) (sale of stock of temporary corporation treated as sale of underlying assets held primarily for sale to customers).

435. 103 F. Supp. 369 (D.C. Cal. 1952). Cf. Frank E. Gilman, 14 T.C. 833 (1950), acq., 1950-2 Cuar. Burs. 2. 
There a playwright-producer obtained capital gains upon the dissolution of his fifty percent-owned corporation immediately after the completion of a single motion picture produced with borrowed funds at the Columbia studios. The Commissioner argued that the income received from the subsequent distribution of the film should be taxed as ordinary income either to the stockholder, on the theory that the corporate entity should be disregarded, or to the corporation, on the theory that it should have reported the income notwithstanding its dissolution. The court found that the corporation had served genuine nontax purposes: it actually produced the film, borrowed on its own credit, and insured the taxpayer's control over the film's artistic aspects. ${ }^{430}$ The court also accepted at face value testimony that the corporation was intended to produce more than one film and that its dissolution was not contemplated until a ten percent stockholder became unwilling to risk his profit in future productions. ${ }^{437}$ The peculiar facts found in Herbert, especially the stockholders' motives for organizing the corporation and for dissolving it, would insulate the stockholders from the collapsible corporation statute if the case had arisen after 1949.438 More important, these findings afforded little opportunity to test the "common law" theories for imposing ordinary rates on the stockholder : the case leaves unanswered the consequences of findings that a corporation was "born to die" or that its stockholder-employees received inadequate compensation. 439

The Herbert case is significant, however, in permitting the stockholder to obtain capital gains on his pre-incorporation services in writing the play, as distinguished from his post-incorporation services in producing the film. As a professional playwright, Herbert would have been taxed at graduated rates if he had sold the play to an established studio either for cash or for a minority stock interest. ${ }^{440}$ The creation of a corporation enabled him to make a taxfree exchange of a non-capital asset (the play) for a capital asset (the stock).441 His capital gain of $\$ 547,000$ upon liquidation largely represented the fruition of his efforts as playwright. ${ }^{42}$ Because motives such as Herbert's could prevent application of the collapsible corporation statute, capital gains on pre-

436. However, there was testimony that obtaining capital gains was discussed prior to incorporation. Herbert f. Riddell, 103 F. Supp. 369, 377 (D.C. Cal. 1952).

437. Id. at 382: "The picture had been released only a short time and very little money was coming in. To buy him out would have involved a large sum of money, which was not available." It would seem that the taxpayer or the corporation could easily have borrowed money to buy him out; the corporation's credit had initially been sufficient to borrow $\$ 400,000$, and the completed film was valued at $\$ 973,886.25$.

438. I.e., because the corporation had not been used "principally . . . with a view to" obtaining capital gains by the stockholders.

439. The $\$ 37,500$ paid to Herbert by the corporation was not found to be inadequate compensation for his services as script-writer and adviser.

440. Goldsmith v. Commissioner, 143 F.2d 466 (2d Cir. 1944) ; Fields v. Commissioner, 189 F.2d 950 (2d Cir. 1951).

441. INT. REv. Code of 1939, §112(b) (5) ; INT. Rev. Code of 1954, § 351 (a).

442. To a lesser degree his gain also represented the return on his cash investment, apparently $\$ 25,000$. 
incorporation services still seem possible unless the Commissioner is able, promptly, ${ }^{443}$ to assess ordinary income tax in the year of incorporation on the theory that the receipt of stock is in payment for the prior services. 144

The 1954 Code preserves the old collapsible corporation statute in Section 341 with only three significant alterations. ${ }^{445}$ The first is the addition of a presumption that a corporation is "collapsible" if its "section 341 assets" have appreciated at least twenty percent over their adjusted basis and represent at least fifty percent of the fair market value of total corporate assets. ${ }^{\text {it }}$ Section 341 assets are assets held for less than three years, consisting of stock in trade and similar property, certain real and depreciable property, ${ }^{\text {tit }}$ and most "unrealized receivables or fees." 448 This presumption may be both too narrow in scope ${ }^{499}$ and too uncertain in effect ${ }^{\mathbf{4 0 0}}$ to accomplish its stated purpose of strengthening the section's effectiveness. ${ }^{251}$

The second change affecting collapsibles does not appear in Section 341 but in Section 337 which deals with the Court Holding Company problem. ${ }^{452}$ Section 337 provides for non-recognition of corporate gain on the sale of assets

443. U.S. Treas. Reg. 118, $\$ 39.112$ (b) (5) -3 (1953) requiring prompt disclosure of the character of property received by a controlled corporation in exchange for its stock, is frequently disregarded. See also note 289 sipra.

444. Section 112(b) of the 1939 Code has been held not to prevent taxation of stock: received for personal services. Fifth Avenue Bank of New York, 31 B.T.A. 945 (1934). An argument could be made that the nonrecognition provisions should also be inapplicable to stock received for property embodying prior personal services. Query whether the new last sentence of Section 351(a) of the 1954 Code taxing stock issued for services applies where a sole stockholder receives stock of a new corporation in exchange for property created by his personal efforts?

445. The Senate rejected the sweeping changes made by H.R. 8300 (House Bill). See H.R. Rep. No. 1337, 83d Cong., 2d Sess. 38, A100-A115 (1954); SEN. Rep. No. 1622, 83d Cong., 2d Sess. 48, 260 (1954).

446. INT. Rev. CODE of $1954, \S 341$ (c) (1). For this purpose total assets exclude cash, stocks of other corporations, obligations which qualify as capital assets, and certain governmental non-interest-bearing obligations. Id. $\$ 341$ (c) (2). For a clue to the valustion of "section 341 assets," see H.R. Rep. No. 1337, 83d Cong., 2d Sess. A114 (1954).

447. Excluded from this category is "property which is or has been used in connection with the manufacture, construction, production, or sale" of stock in trade and similar property. Id. $\$ 341$ (b) (3) (D).

448. This phrase is defined to "mean" any rights to ordinary income from "goods delivered or to be delivered" and "services rendered or to be rendered" to the extent that such rights were not previously includible in income. $I d$. $\$ 341$ (b) (4). This definition is identical with that in $\$ 751$ (c) relating to partnerships except for the unexplained substitution of "means" for "includes."

449. The definition of "unrealized receivables or fees" may not include rights to future rental, royalty, and similar payments which are often distributed by temporary corporations at the time of liquidation. See note 248 sipra.

450. Section 341 (c) fails to specify how the new presumption is intended to augment the familiar presumption in favor of the Commissioner's determinations under Tax Court Rule 32.

451. SEN. REP. No. 1622, 83d Cong., 2d Sess. 260 (1954). See also H.R. REP. No. 2543, 83d Cong., 2d Sess. 37 (1954).

452. See text at note 464 infra. 
(except stock in trade) within twelve months after the adoption of a plan of complete liquidation. And it eliminates even the tax on ordinary income from the sale of stock in trade if substantially all is sold "to one person in one transaction." 453 The benefits of Section 337 are specifically denied to a "collapsible corporation as defined in Section 341 (b),"454 but Section 337 may itself prevent a corporation from being "collapsible" under Section 341(b). A taxpayer could apparently take advantage of Section 337 by (a) forming a singleventure corporation to construct a building or produce a motion picture, (b) causing the corporation to adopt a plan of complete liquidation, and (c) then causing it to "realize" its profit by a sale of all its assets, including the completed building or film, "to one person in one transaction" within twelve months. Since the corporation has "realized" a "substantial part of the taxable income to be derived" from the building or film, it would not literally be "collapsible" under Section 341 (b). This would mean capital gains for the stockholders and non-recognition of the corporation's gain under Section 337. Thus the profit from the building or film would be taxed as ordinary income to no one. In view of Congress' clear intent to deny the benefit of Section 337 to collapsible corporations, the courts may balk at this use of Section 337 to frustrate the purpose of Section 341.455

The third 1954 amendment affecting collapsible corporations is found in Section 312(b). This new provision requires that distributions in kind of appreciated "inventory assets" 456 be accompanied by a special adjustment of the corporate "earnings and profits" account to reflect the excess of the current value of such assets over their basis to the corporation. ${ }^{457}$ This adjustment is

453. INT. REv. CODE of 1954, § 337 (b) (2).

454. Id. $\$ 337$ (c) (1) (A). This cross-reference could be interpreted to mean that "collapsible corporation" status is to be determined without the presumption created by $\S 341$ (c) which, by its terms, is applicable only "for the purpose of" $\$ 341$. Thus a corporation might not be "collapsible" under $\$ 337$ even though "collapsible" under $\$ 341$, with the result that the corporate tax would be eliminated but the stockholders would be taxed at ordinary rates. Similarly, the cross-reference may mean that "collapsible corporation" status under $\S 337$ is to be determined without regard to the limitations in $\S 341$ (d) which, by their terms, apply only "[i]n the case of gain realized by a sharcholder ..." with the result that the corporate tax might be imposed when the shareholder would not be taxed at ordinary rates.

455. See text at notes 59-61 supra.

456. Despite apparent similarity, the definition of "inventory assets" in $\$ 312(\mathrm{~b})(2)$ differs in several respects from that of "section 341 assets" in $\$ \S 341$ (b) (3), (4) (relating to collapsible corporations) discussed in notes 447 and 448 supra, and that of "unrealized receivables" and "inventory items" in $\$ \$ 751$ (c), (d) (relating to partnership interests) discussed in text at notes 247-9 supra.

457. INT. REv. CODE of $1954, \S 312$ (b) requires that earnings and profits be (A) increased by the excess of the fair market value of the inventory assets distributed over their adjusted basis, and $(B)$ decreased by the lesser of their fair market value or the earnings and profits as increased under (A). Section 312 (b) represents an exception to the general rule of $\S 312$ (a) requiring that earnings and profits be decreased merely by the adjusted basis of assets distributed in kind.

The general rule under the 1954 Code is that a distribution of money and/or property 
intended to insure "that the shareholder will always pay a [dividend] tax on the [current] value of the inventory." 458 It thus prevents him from receiving the "inventory assets" as a return of capital or as capital gain, even though the distribution is made before the corporation has realized any income from the distributed assets or after the corporation has distributed all "earnings and profits" from its other activities. ${ }^{459}$ Because Section $312(\mathrm{~b})$ is effective only where the stockholders receive assets in a simple distribution in kind, ${ }^{400}$ but not where the corporation is dissolved or its stock is sold, it is significant less for what it accomplishes than for being the first legislative attempt to deal with collapsible corporations without reliance upon the unsatisfactory 1950 statute. $^{461}$

(2) Tax Treatment of Corporation. The collapsible corporation statute employs a test of "substantial" realization of income by the corporation, but it does not provide criteria for determining how much income has been realized by the corporation. Successful use of the collapsible corporation scheme presumes that the corporation will not be taxed on the income received by the stockholder after the corporation has distributed the property produced by it or claims to income from that property. This assumption is based largely on the General Utilities ${ }^{402}$ principle that a corporation does not realize income on the distribution in kind of capital assets which have appreciated in value. ${ }^{463}$

During the past decade, however, the courts have begun to distinguish the General Utilities rule when the assets distributed consist of claims to unrealized income produced by the corporation's activities. This development has several roots. One is the Court Holding Co. case, ${ }^{404}$ which taxed a corporation when its stockholders closed a sale of real property distributed in kind to them after the corporation had completed negotiations with the purcliaser. Another is a series of decisions sustaining the Commissioner's power under the old Section $41^{465}$ to attribute income to dissolved corporations which had used

is taxable to stockholders as a dividend only to the extent that the amount of the money and/or the fair market value of the property distributed is deemed to be out of corporate earnings and profits. INT. REv. CODE OF 1954, $\$ \$ 301$ (b), (c), 312(a), 316(a).

458. H.R. REP. No. 1337, 83d Cong., 2d Sess. 38 (1954).

459. Where $\S 117(\mathrm{~m})$ was inapplicable under the 1939 Code, the entire amount of the distribution could theoretically be a dividend if the corporation had but a single dollar of earnings and profits, while no part of the distribution would be taxable at ordinary rates if earnings and profits were zero. This rule was applied to capital as well as to inventory assets. Commissioner v. Hirshon Trust, 213 F.2d 523 (2d Cir. 1954); Commissioner v. Estate of Godley, 213 F.2d 529 (3d Cir. 1954).

460. The amount of earnings and profits does not affect the tasability of liquidating distributions.

461. H.R. Rep. No. 1337, 83d Cong., 2d Sess. 38 (1954).

462. General Utilities \& Operating Co. v. Helvering, 296 U.S. 200 (1935).

463. The regulations extend this rule to distributions in liquidation and apparently to distributions of non-capital assets. U.S. Treas. Reg. 118, $\$ 39.22$ (a)-20 (1953).

464. Commissioner v. Court Holding Co., 324 U.S. 331. (1945).

465. INT. REv. CODE of 1939, §41 provided that where the method of accounting employed by the taxpayer "does not clearly reflect the income, the computation shall be made 
the "completed contract" method of accounting.468 Still another source may be the Supreme Court cases taxing assignors on assigned income. ${ }^{407}$

No rule of thumb exists as yet for determining whether a corporation will be taxed on income generated by its activities if its claims to this income are distributed to stockholders and collected by them. At least two possibilities are suggested by the cases to date. The first is that the income is taxable to the corporation, even though on the cash-basis, if it would have accrued to a corporation on the accrual basis. Thus in Floyd v. Scofield, ${ }^{408}$ a cash-basis oil brokerage corporation was taxed on commissions received by its stockholder around October 20th for services performed by the corporation during the month of September notwithstanding its dissolution on October 2nd.400 A second possibility is that the corporation will be taxed when it has done everything necessary to generate the income in an economic sense, even though at the time of the distribution the income would not be accruable under the principles of accrual-basis accounting. This "economic" test is directed chiefly toward operating income; but it can be supported by Court Holding Co. inasmuch as the sales profit there would not have accrued before the distribution because the purchaser was not then liable for the price under the Florida statute of frauds. Further authority for this test is found in several decisions taxing accrual-basis corporations on income which had not accrued before distributions in kind to stockholders. ${ }^{470}$ However, this rule has been said to

in accordance with such method as in the opinion of the Commissioner does clearly reflect the income." INT. REv. CoDE of 1954, $\S 446$ (b) restates the rule with minor changes in phraseology.

466. Jud Plumbing and Heating, Inc. v. Commissioner, 5 T.C. 127 (1945), aff d, 153 F.2d 681 (5th Cir. 1946) (corporation held taxable upon percentage of the total profit on jobs that were incomplete at time of dissolution) ; Standard Paving Co. v. Commissioner, 13 T.C. 425 (1949), aff'd, 190 F.2d 330 (10th Cir. 1951) (dissolved stubsidiary held taxable on percentage of profit on jobs unfinished at time of "tax-free reorganization"). Cf. Guy M. Shelley, 2 T.C. 62 (1943).

467. E.g., Lucas v. Earl, 281 U.S. 111 (1930) ; Helvering v. Horst, 311 U.S. 112 (1940). Cf. United States v. Joliet and Chicago Ry., 315 U.S. 44 (1942). But see Campbell v. Prothro, 54-1 U.S. TAX CAS. $\Uparrow 9155$ (5th Cir. 1954).

468. 193 F.2d 594 (5th Cir. 1952).

469. See also First-Nat. Bank of St. Elmo, Ill. v. United States, 194 F.2d 389 (7th Cir. 1952) (cash-basis bank taxed on proceeds of sale of mineral rights notwithstanding prior dividend in kind of bank's claim); Atlas Steamship Co., 18 B.T.A. 654 (1930) (cash-basis corporation taxed on proceeds of insurance on lost vessel received by stockholders notwith. standing prior dividend in kind of corporation's claim against insurance company). But cf. United States v. Horschel, 205 F.2d 646 (9th Cir. 1953) (cash-basis corporation held not taxable upon proceeds of post-liquidation sales of apples). The Horschel case is reconcilable on the ground that the income was neither accruable nor "earned" in an economic sense by the corporation prior to its liquidation.

470. Commissioner v. First State Bank of Stratford, 168 F.2d 1004 (5th Cir. 1948), reversing, 8 T.C. 831 (1.947), cert. denied, 335 U.S. 867 (corporation taxed on collection of notes previously charged off as worthless notwithstanding distribution of notes to stockholders); United States v. Lynch, 192 F.2d 718 (9th Cir. 1951), cert. denicd, 343 U.S. 934 (1952) (corporation taxed on ordinary income from sale of inventory of apples distributed in kind to stockholders and subsequently sold by corporation as their "agent"); Samuel 
apply only where the distribution is by a continuing corporation rather than one in liquidation. ${ }^{471}$

The courts have given no clear indication whether they will adopt an "accrual" test, an "economic" test, or possibly some third test. Herbert ". Riddell ${ }^{472}$ rejected the "economic" test by holding that the corporation was not taxable on income from the film distribution contract transferred to the stockholders in liquidation. ${ }^{473}$ This income would not have been taxable to the corporation under the "accrual" test because it was not accruable at the time of the liquidation, even though it required no future activity by the corporation or its stockholders and could be estimated in amount very closely.474

(3) Distribution of Contingent Clainns. Adoption of an "accrual" test would facilitate corporate tax avoidance in personal service situations other than collapsible movie corporations. The possibilities are illustrated by Susan J. Carter. ${ }^{475}$ There a sole stockholder dissolved a corporation which for many years had acted as an oil broker. Its corporate income consisted primarily of commissions for sales of oil arranged by the stockholder's husband as president. The commissions were expressly contingent upon delivery of the oil by the seller and receipt by him of the sales price. Before dissolution the corporation had performed services under certain brokerage contracts but had not reported the commissions because it was on the cash-basis. Subsequently over $\$ 43,000$ of such commissions were received by the stockholder. The Commissioner successfully invoked an accrual theory, asserting that the corporation was taxable on $\$ 8,000$ of these commissions attributable to sales of oil delivered and paid for before it dissolved. But both Tax Court and Second Circuit upheld the taxpayer's contention that the remaining $\$ 35,000$ was taxable to her only as capital gain. They reasoned that since the claims were admitted to have no fair market value for computing capital gain at the time of the liquidation, the

Donner, 12 T.C.AI. 1335 (1953) (corporation held tasable on ordinary income from sales made after its complete liquidation under sales agency contract previously negotiated by" corporation) ; Rudco Oil \& Gas Co. v. United States, 82 F. Supp. 746 (Ct. Cl. 1949) (corporation taxed on proceeds from sale of oil and gas notwithstanding temporary assignment of lease to stockholders). See SEN. REp. No. 1622, 83d Cong., 2d Sess. 247 (1954) : "your committee does not intend to change existing law with respect to attribution of income of shareholders to their corporation as exemplified for example in the case of Commissioner v. First State Bank of Stratford."

471. United States v. Horschel, 205 F.2d 646, 649 (9th Cir. 1953); Commissioner v. Henry Hess Co., 210 F.2d 553, 558 (9th Cir. 1954) (accrual-basis corporation held not taxable on profit which was neither determinable nor received until after its dissolution).

472. See text at notes $435-44$ supra.

473. The Commissioner apparently relied upon U.S. Treas. Reg. 118, \$39.3797-2 (1953) to support an economic test: "If the conduct of the affairs of a corporation continues after ... the termination of its existence, it becomes an association."

474. "Competent evidence" valued the film at $\$ 973,866.25$ as of the time of the distribution. Herbert v. Riddell, 103 F. Supp. 369, 382 (D.C. Cal. 1952).

475. 9 T.C. 364 (1947), roin-acq., 1948-1 Cus. BuLL 4, aff'd, 170 F.2d 911 (2d Cir. 1948). 
liquidation was an "open transaction" so that the commissions subsequently collected by her were treated as received in exchange for the stock. ${ }^{\mathbf{4 7 0}}$

The Carter case is to be contrasted with the liquidation of a cash-basis corporation holding unpaid claims for oil brokerage commissions not contingent upon delivery. This apparently was the situation in Floyd $v$. Scoficld. ${ }^{477}$ There the claims could be "accrued" by the corporation and would have fair market value in the hands of the stockholders. Accordingly the commissions, less a reserve for doubtful accounts, would be includible in corporate income for the year ending with the dissolution. Presumably, an equal amount would be inclucled in computing the stockholder's capital gain upon the liquidation, with the result that the amounts later collected would be tax-free to the stockholder up to this amount ${ }^{478}$ and ordinary income to the extent that they exceeded it. ${ }^{470}$ This treatment of the commissions on the corporate and stockholder levels would be selfconsistent: the entire amount of the commissions would be taxed once as ordinary income, either to the corporation or to the stockholder.

Viewed against this background, the Carter result makes little sense. Solely because the commissions in Carter were subject to a contingency at the time of dissolution, they escaped tax as ordinary income, both at the corporate level and at the stockholder level. If the contingency prevents the commissions from being taxed to the corporation, it would not seem illogical to omit the contingent claims in computing the stockholder's capital gain at the liquidation and to tax the collection of the claims as ordinary income from personal services. Until and unless the "economic" test is adopted ${ }^{480}$ or the Carter treatment of the stockholder overruled, ${ }^{481}$ the way is clear for the conversion of personal

476. This interpretation was based upon Burnet v. Logan, 283 U.S. 404 (1931), holding that where stock was sold for future payments based upon coal to be obtained from a mine, the seller of the stock did not realize capital gain until the payments exceeded the cost of the stock. Logan involved no corporate tax avoidance because the income from the coal operations was presumably subject to corporate tax before payment to the seller.

477. See text at note 468 supra.

478. INT. REv. CODE OF 1954, $\$ 334$ (a) codifies the rule that fair market value of property distributed in a corporate liquidation is the distributee's basis.

479. Lewin v. Westover, 53-2 U.S. TAx CAS. $\mid 9619$ (D.C. Cal. 1953) (income from film distribution contract held ordinary income to stockholders to the extent that it excecdecl estimate used in computing capital gain upon liquidation). See also Osenbach v. Commissioner, 198 F.2d 235 (4th Cir. 1952).

480. It is not clear whether the Commissioner would attempt to tax the corporation on the entire commissions if the Carter case were to arise again. See Rev. Rul. 255, 1953 INT. REv. Butz. No. 24, at 2 (1953) (accrual-basis corporation in dissolution taxable on commissions for completed brokerage services although (a) commissions did not become payable until after shipment of goods by seller and (b) taxpayer's consistent practice was to accrue commissions only after shipment). The ruling fails to state whether the claims for commissions were contingent upon actual shipment.

481. This is unlikely because of Arrowsmith v. Commissioner. See note 358 supra. The Court's viewing together all the 1937-1944 liquidation events in order to determine the nature of the 1944 loss seems to support the Carler "open transaction" concept. But it can be argued that the Arrozesmith principle should cause the commissions to retain their character as ordinary income even though received by the stockholders rather than the corporation. 
service income into capital gain without payment of corporate tax by liquidating corporations with contingent claims to income. ${ }^{482}$

\section{Disposing of the Stock}

With few exceptions the sale of all or a part of the taxpayer's stock is a legally certain way to capital gains on the appreciation in its value attributable to his efforts. Practically, however, the stockholder may encounter difficulty finding a purchaser willing to pay a satisfactory price for the stock, especially if it is a minority common stock interest in a closely-held corporation. ${ }^{453}$ And this difficulty is intensified in the case of the typical personal service enterprise in which corporate earning power is largely dependent upon the activities of the original stockholders, although its stock may have some value to an outsider by reason of accumulated earnings or good will. A second major difficulty with a sale of common stock is that the seller loses at least part of his stake in the future of the enterprise. Taken together, these factors tend to reduce the size of the capital gain and to prevent its repetition.

Redemption ${ }^{484}$ of the stock by the corporation eliminates both dilution of interest and the search for a purchaser, but it raises a new question, whether part of the amount received may be taxed at graduated rates either as compensation or as a dividend. The employee who sells his stock to the corporation usually runs only a mild risk of receiving taxable compensation. The Commissioner may find it difficult to establish an intent to compensate even where he can prove the redemption price to be in excess of reasonable value of the stock. ${ }^{485}$ In the absence of this excess value his difficulties are still greater. Thus in the typical case the sale is pre-arranged in the employment contract, which sets a price-frequently by a formula based on book value-at which the employer must buy and the employee must sell upon terminating his employment. Although the few decisions to date sanction capital gains treat-

482. The Commissioner may also (a) contend that Carter is inapplicable where any services remain to be performed after the liquidation and (b) contest the fact that the claims are completely devoid of fair market value, unlike the Carter case where he apparently agreed to this crucial fact. Although film distribution contracts have been held to have fair market value, Lewin v. Westover, 53-2 U.S. TAx CAS. I 9619 (S.D. Cal. 1953), the courts are unlikely to find fair market value where the claim is subject to a contingency similar to that in Burnet v. Logan, supra note 476. See, e.g., Westover v. Smith, 173 F.2d 90 (9th Cir. 1949).

483. Cf. Estate of Charles W. Heppenstall, 8 T.C.11. 136 (1949) (minority interest in closely-held corporation valued at less than book value for gift tax purposes because holder could not compel liquidation).

484. The trend of recent decisions is to classify a sale of stock to the issuing corgorations as a "redemption" which may be subject to dividend taxation under INT. REv. CODE OF 1939, $\S 115(\mathrm{~g})(1)$, even though the corporation does not retire the acquircd shares but holds them as treasury stock. See authorities collected by Murphy, How to Handle Treasury Stocl:; Distinction between Treasury Stock and Unissued Stock: Is There Any Justification for This? N.Y.U. 10TH INST. ON FED. TAX. 1161 (1952). This interpretation is made statutory by INT. REv. CODE OF 1954, $\$ 317$ (b).

485. See text at note 311 supra. 
ment of the employee under agreements of this general type, ${ }^{486}$ the entire gain might be compensation where the employee's rights are so limited that he can be regarded as never having owned stock at all.

The dividend risk is minimal for the stockholder, such as the typical nonproprietor, who surrenders his entire stock interest in the corporation; but a proprietary stockholder is ordinarily unwilling to sacrifice all or a substantial part of his interest in the control and future growth of the business, ${ }^{487}$ or to liquidate the corporation and operate it in unincorporated form. ${ }^{488}$ If the proprietor surrenders a part of his stock without terminating or substantially reducing his proportionate interest in the corporation, the redemption payment will probably be taxed to him as a dividend. ${ }^{480}$ Accordingly, the major objective of controlling stockholders has been to find methods to pocket the appreciation in value of their corporation with neither a loss of their proportionate interest in the enterprise nor a dividend tax-to have their cake and eat it too.

To date Congress, the courts, and the Commissioner have blocked some but not all of these methods. If the stockholder attempts to withdraw corporate earnings at capital gains rates by a complete liquidation preceded ${ }^{400}$

486. See, e.g., Estate of Raymond T. Marshall, 20 T.C. 979 (1953) (capital gain allowed to retiring employee who sold stock for price measured by dividends of next ten years). C/. Patent Button Co. v. Commissioner, 203 F.2d 479 (2d Cir. 1953), affirming, 11 T.C.M. 262 (1952) (employer corporation denied compensation deduction for amounts paid to former employee upon exercise of option to resell stock at current book value which he had purchased at 80 percent of book value). See also Willard D. Avery, Tax Court Docket No. 49397 (1953) (additional compensation alleged to arise upon compulsory resale at book valuc by retiring employee of stock purchased at book value; corporate employer attempted to deduct part of the purchase price).

487. Where the owners of the corporation are willing both to relinquish its control and to accept stock of a corporate purchaser in full or part payment for their old stock, the exchange can be set up as a "reorganization" (see note 432 supra), thus deferring or eliminating all or part of the capital gains tax, depending upon whether "boot" is also received and whether the new stock is retained by the seller until his death. For the definition of "nonproprietor" see note 291 supra.

488. When the enterprise is continued in unincorporated form, the stockholder's capital gain tax upon the liquidation may be substantially increased by the good will acquired by him. See Schwartz, Good Will in the Tax Law: A Correlation, 8 TAx L. Rev. 96, 98 (1952).

489. Int. Rev. CoDE of 1939, § 115 (g) (1) ; INT. Rev. CoDE of 1954, § 302 (b) (1), (2), (3). Pro rata redemptions have occasionally been held not to be "essentially equivalent to a dividend" where the redemption served some legitimate non-tax purpose: (1) segregation of risky activities, John L. Sullivan, 17 T.C. 1420 (1952), aff'd, 210 F.2d 607 (5th Cir. 1954); L. M. Lockhart, 8 T.C. 436 (1947) ; (2) facilitation of employee stock purchases, Commissioner v. Snite, 177 F.2d 819 (7th Cir. 1949); (3) improvement of corporate credit standing, Isaac C. Eberly, 10 T.C.M. 1.157 (1951); (4) reflection of contraction in volume of business, Clarence R. O'Brien, 10 T.C.M. 1122 (1951).

The 1954 Code effects two principal changes: $\$ 302$ (c) adds constructive ownership rules, and $\$ 302$ (b) (5) provides that in determining whether a redemption is "essentially equivalent to a dividend," no weight shall be given to the fact that the redemption is not substantially disproportionate. See also the new definition of "partial liquidation" in $\$ 346$.

490. Lewis v. Commissioner, 176 F.2d 646 (1st Cir. 1949), discussed by Wittenstein, Boot Distributions and Section 112(c)(2); A Re-examination, 8 TAx L. Rev. 63 (1952). 
or followed 491 by the transfer of some of the assets to another controlled corporation, the two steps may be viewed together as a "reorganization" 492 coupled with a dividend.403 And if he seeks to effect a tax-free division of the corporation into two or more corporations, one of which is then sold or liquidated, the couris are likely to view the successive steps as a single transaction, not within the spirit of the non-recognition provisions, and levy a dividend tax 194 whether the divisiun takes the form of a "split-up,"495 "split-off,"400 or "spin-off."407 This risk is increased by Section 355 of the 1954 Code. The new section expressly hinges the tax-free status of all types of corporate divisions ${ }^{405}$ on two conditions

See also Ernest F. Becher, 22 T.C. No. 112 (1954); William MI. Lidden, 22 T.C. No. 150 (1954).

491. Survaunt v. Commissioner, 162 F.2d 753 (Sth Cir. 1947). See Bittker \& Redlich, Corporate Liquidations and the Income Tax, 5 TAX L. Rev. 437, 453-5 (1950). But see United States v. Arcade Company, 203 F.2d 230 (6th Cir. 1953); Charles R. Mrathis, Jr., 19 T.C. 1123 (1953).

492. INT. Rev. CODE of 1939, §112(g) (1) (D) ; INT. Rev. CODE of 1954, §36\$(a) (1)(D).

493. INT. REv. CODE of 1939, §112(c) (2) and/or $\$ 115$ (g) (1), U.S. Treas. Reg. 118, $\S 39.112$ (g)-1(b) (1953) ; INr. REv. CODE of 1954, \$ 302(b) (1) and/or § 356(a) (2). Seetion 357 of H.R. 8300 (House Bill) provided that an individual should be deemed to receive a taxable "boot" distribution if he failed to prove that tax avoidance was not one of the "principal purposes" of a tax-free transfer to a 50 percent-owned corporation of more than 50 percent of the assets received by him during the past 5 years in the complete or partial liquidation of another corporation. This provision was eliminated by the Senate. See H.R. REP. No. 2543, 83d Cong., 2d Sess. 41 (1954) (the Conference Report) : "[T] he possibility of tax: avoidance in this area is not sufficiently serious to require a special statutory provision. It is believed that this possibility can appropriately be disposed of by judicial decision or by regulation within the framework of the other provisions of the bill."

494. See Danzig, Distribution of Corporate Operations with a Fiew to Sale of Parl of the Business, N.Y.U. 11tr Inst. on FED. TAx. 891 (1953); Afichaelson, "Business $P_{\text {:ur- }}$ pose" and Tax-Free Reorganization, 61 YALE L.J. 14 (1952).

495. An exchange of all assets of the old corporation for the stack of two or more new corporations, followed by dissolution of the old corporation and distribution to its shareholders of the stock of the new corporations was tax-free under Ist. REv. Cuviz of 1939, $\$ \$ 112$ (b) (3), (g)(1)(D). See Johnson, Split-Offs and Split-Ups, N.Y.U. 11тu I:ust. ON FED. TAX. 285 (1953).

496. An exchange of part of the assets of the old corporation for the stock of one or more new corporations, followed by distribution of the stock of the new corporation(s) to the shareholders of the old corporation in exchange for a part of the old corporation's stod:

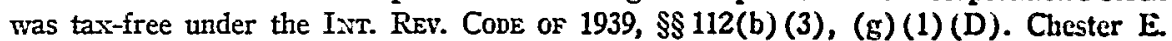
Spangler, 18 T.C. 976 (1952), acq., 1953-1 Cuar. Bull 6; Rev. Kul. 289, 1953 Ist. Rew. BuLc. No. 26, at 10.

497. A "spin-off" was similar to a "split-off" except for (a) the retention by the shareholders of all of their stock in the old corporation and (b) additional statutory requirements intended to prevent tax-avoidance. INT. REv. CODE of 1939, $\S 112$ (b) (11), (g)(1)(D). See Rapp, Spin-Offs, N.Y.U. 11tr Inst. on Fed. TAx. 343 (1953). Cf. Rev. Rul. 5t-139, 1954 INT. REV. BULL. No 16, at 8 ("spin-off" tax-free where sole stockholder has no intention of seiling or otherwise disposing of any stock of either corporation or liquidating either corporation).

498. See Sen. Rep. No. 1622, 83d Cong., 2d Sess. 266 (1954). 
derived from, but broader than, those set forth in the 1951 "spin-off" amendment. ${ }^{499}$ First, a distribution by corporation $A$ of the stock of its 80 percent controlled ${ }^{500}$ corporation $B$ will be tax-free only if $A$ 's stockholders can prove that "the transaction was not used principally as a device for the distribution of the earnings and profits of the distributing corporation or the controlled corporation or both." 501 Secondly, each corporation must engage in "the active conduct of a trade or business" immediately after the distribution. ${ }^{502}$ This prevents a corporation from segregating liquid assets purchased with earnings in a separate corporation and then distributing its stock tax-free. Section 355 also hinders a corporation from using its earnings to form or buy up a second business in order to make a tax-free distribution of stock in that business. The distribution is taxable if, during the five preceding years, the new business was acquired for consideration consisting in any part of cash or property other than stock or securities of the acquiring or a related corporation. ${ }^{\text {not }}$ However, it still seems possible to siphon off earnings through a divisive reorganization if the corporation buys and holds a secondary business for at least five years before the distribution. ${ }^{504}$

\section{Sales to Sister Corporations}

Multiple corporations facilitate capital gain withdrawals, especially if an enterprise can be divided among several "sister" corporations initially, or if a going corporation can be so divided without incurring a dividend tax. Ordinarily, the sale or dissolution of even an inessential branch of the business, c.g., one store in a retail chain, has at least one disadvantage : the branch is lost to the owners or must be operated in unincorporated form. And a personal service enterprise typically has no expendable functions. However, no part of the

499. INT. REv. CoDE of 1939, §112(b) (11), added by Revenue Act of 1951, §317 (a), 65 STAT. 452 (1951).

500. INT. REV. CODE OF 1954, \$ 368(c).

501. Id. \$355(a) (1) (B). Cf. U.S. Treas. Reg. 118, §39.112(b) (11)-2(d), Examples (1953). Section 355 may be more lenient than the old section 112 (b) (11) because of the addition of a provision that a sale of stock or securities in one or more of such corporations, unless negotiated before distribution, "shall not be construed to mean that the transaction was used principally as such a device."

502. INT. Rev. CoDE of 1954, $\$ 355$ (b) (1) (A). An exception is provided for certain holding companies. Id. $\$ 355$ (b) (1) (B).

503. Id. $\S \S 355$ (b) (2) (B), (C), (D). See also id. $\S 368$ (a) (1) (C) and (b) (acquisition of assets in exchange for stock of corporation in control of the acquiring corporation) discussed in SEn. Rep. No. 1622, 83d Cong., 2d Sess. 263, 273, 275 (1954).

504. By a happy coincidence, the 80 percent stock ownership required by $\$ 355$ maly allow the parent to accumulate surplus for the reasonable needs of the new subsidiary. Sec SEN. Rep. No. 1622, 83d Cong., 2d Sess. 70 (1954): "where the taxpayer has 80 percent or more of the voting stock of another corporation, the taxpayer should be viewed as though it engaged directly in the business of such other corporation." Since no provision to this effect appears in the statute itself, it is not clear how much weight will be accorded to this Congressional dictum. For a typical pre-1954 Code decision see Latchis Theatres of Kcenc, Inc. v. Commissioner, 54-2 U.S. TAX CAS. If 9544 (1st Cir. 1954). 
business need be sacrificed or operated in unincorporated form when it is sold to a sister corporation.

Before the 1954 Code a stockholder, $X$, controlling several corporations could withdraw earnings as capital gains by selling part of his stock in corporation $A$ to corporation $B$, and part of his $B$ stock to $A$. 505 These cross-sales are largely blocked by the new Section 304. Now, if $A$ purchases stock of $B$ from $X$, a person in control ${ }^{506}$ of both corporations, the full payment by $A$ is treated as a distribution in redemption of $A$ 's own stock, ${ }^{507}$ but the character of this distribution is made to depend upon the extent of any change in X's proportionate ownership of $B . .^{508}$ Because $X$ is deemed to continue to own his $B$ stock constructively through $A$, ${ }^{509}$ the transaction does not result in a termination or substantial reduction of his interest in $B .510$ Consequently, the entire distribution ${ }^{511}$ will usually be taxed to $X$ as a dividend. ${ }^{512}$

While the 1954 Code limits dividend tax avoidance through intercompany sales of stock, it opens new avoidance possibilities through intercompany sales of assets. Section 337, the Court Holding Co. provision, eliminates corporate tax on sales of assets made within one year after the adoption of a plan of complete liquidation, including the sale of non-capital assets if sold to "one person in one transaction." 513 This section might allow the controlling stockholder to withdraw earnings of both corporations as capital gain by causing

505. Emma Cramer, 20 T.C. 679 (1953) (capital gains allowed upon sale of stock in three corporations to a fourth, all of which were owned in nearly the same proportions by selling stockholders). In Commissioner v. Wanamaker, 178 F.2d 10 (3d Cir. 1949), \$115 (g) (1) of the 1939 Code was construed to be inapplicable to the purchase of stock of its parent by a subsidiary corporation because the subsidiary did not redeem or cancel "its" stock. Section $115(\mathrm{~g})(2)$ was enacted in 1950 to overrule the W'asamalser case but the Senate refused to extend $\S 115(\mathrm{~g})$ to purchases of stock by "sister" corporations. SE:r. REP. No. 2375, 81st Cong., 2d Sess. 43 (1950).

506. INT. REv. CODE of 1954, $\$ 304$ (c) (1). For this purpose "control" is defined as the ownership of stock possessing 50 percent of the voting power or 50 percent of the total value of all classes of stock. A person is deemed to control a subsidiary of a controlled corporation.

507. Id. $\$ 304$ (a) (1). The amount, if any, taxable as a dividend is limited by the earnings and profits of corporation $A$ rather than corporation $B$. Id. $\S 304$ (b) (2) (A).

508. Id. $\$ 304$ (b) (1).

509. For the purpose of determining whether a redemption is exempt from dividend tax as a "substantially disproportionate distribution" under id. $\$ 302(\mathrm{~b})(2)$, a person is deemed to own stock held by related taxpayers including his proportionate interest in stocl: held by certain corporations. Id. $\$ \$ 302$ (c) (2), 318(a). For the purposes of $\$ 304$, a tas:payer is also deemed to own stock held by an intermediate corporation even though he does not own, either directly or constructively, a 50 percent interest in the intermediate corporation. Id. $\S 304$ (b) (1).

510. Id. $\$ 302(\mathrm{~b})(2),(3)$.

511. $X$ 's basis for his $B$ stock is not subtracted from the amount received from $A$ but is added to his basis for his $A$ stock as if he had made a contribution of capital to $A$. Id. $\$ 304(\mathrm{a})$ (1), last sentence.

512. Unless he could make a factual showing that the distribution was not "essentially equivalent to a dividend." Id. \$302(b) (1). See note 489 supra.

513. See text at notes $452-5$ supra. 
corporation $B$ to adopt a plan of complete liquidation, sell its operating assets and good will to corporation $A$, and then distribute to him the sales proceeds and its other liquid assets. ${ }^{\mathbf{5 1 4}}$

\section{Sales of Preferred Stock Dividends}

A sale of non-voting, non-participating preferred stock was another pre-1954 device used by proprietary stockholders to obtain capital gains without inpairment of their control or interest in future corporate growth. The theory of this device was to issue preferred shares to the common stockholders as a tax-free stock dividend ${ }^{515}$ or recapitalization. ${ }^{516}$ A fractional part of each stockholder's basis for his common stock would then become his basis for the preferrecl shares, ${ }^{517}$ so that the sale of the preferred at or near its market value would result in capital gain. Later the circle could be closed by redeening the preferred from its purchaser.

Prior to the 1954 Code, the Commissioner took the position that if, at the time of a preferred stock dividend or recapitalization, there was a plan to sell the preferred, the preferred shares should not be received tax-free or their sale should give rise to ordinary income. ${ }^{518}$ In C.P. Chamberlin, ${ }^{\mathbf{5 1 0}}$ the Tax Court accepted at least the first of these theories and taxed as a dividend a clistribution of preferred stock which had been tailored to the specifications of the purchaser, even to the extent of mandatory annual retirements commencing sixteen months after the issuance. The Tax Court was reversed by the Sixth Circuit and certiorari was denied.520 Even if other circuits accept the Commissioner's theories as to pre-1954 transactions, it is doubtful that they will employ them in less obvious cases, e.g., where there is a substantial interval between the issuance of the preferred and the making of arrangements for its

514. The controlling stockholder would receive $B$ 's earnings and any earnings of $A$ received by $B$ as part of the sales price of $B$ 's assets. But query whether the liquidation of $B$ is "complete" under Section 337?

515. See, e.g., Strassburger v. Commissioner, 318 U.S. 604 (1943) (dividend of preferred shares on common ruled tax-free where only common was outstanding).

516. Under Int. Rev. Code of 1939, $\$ \S 112$ (b) (3), (g) (1) (E), or INT. Rev. Code of 1954 , $\$ 3354$ and 368 (a) (1) (E), the surrender of old common in exchange for new common and preferred would be tax-free to the stockholders, assuming the presence of "business purpose" for the transaction. See Platt, Preferred Stock Dividends and Recapilalizalions after the Basley and Adams Cases, N.Y.U. 7TH INST. ON FED. TAX. 561 (1949).

517. Int. Rev. CoDE or 1939, $\$ \S 113$ (a) (6), (19) ; INT. Rev. Code of 1954, $\S \S 307,358$.

518. His theories were that the preconceived sale changed the stockholders' proportionate interests in the corporation, so that the preferred stock dividend was not within the rationale of Eisner v. Macomber, 252 U.S. 189 (1920) ; Helvering v. Griffiths, 318 U.S. 371 (1943) ; Strassburger v. Commissioner, 318 U.S. 604 (1943); and Helvering v. Sprouse, 318 U.S. 604 (1943), and that the transaction was in substance a sale of the preferred by the corporation followed by a cash dividend of the sales proceeds. See Darrell, Recent Developments in Non-taxable Reorganizations and Stock Dividends, 61 HARv. L. REv. 958 (1948); DeWind, Preferred Stock "Bail-Outs" and the Incone Ta.x, 62 Hanv. L. Riw. 1126 (1949).

519. 18 T.C. 164 (1952).

520. Chamberlin v. Commissioner, 207 F.2d 462 (6th Cir. 1953), cert. denied, 347 U.S. 918 (1954). 
sale or redemption. This state of the law presented several practical obstacles to the use of the preferred stock "bail out" by a personal service corporation. Outsiders would be likely to invest in a corporation dependent on the activities of a few individuals only in reliance upon rapid redemption provisions. These provisions would increase the tax risk of the common stockholders. Near relatives or business associates might be willing to gamble on the permanence of the corporation's personnel, but a redemption of preferred stock sold to them might be taxed as a dividend. 521

After a bad start in the House Bill, ${ }^{022}$ the 1954 Code has drastically curtailed the capital gains benefits of preferred stock. Section 306 provides that if preferred shares are distributed as a stock dividend ${ }^{523}$ or in a tax-free reorganization, the entire proceeds of their subsequent sale will be treated as gain from sale of a non-capital asset to the extent that a cash distribution equal to the fair market value of the stock at the time of the stock distribution would have been taxed as a dividend at that time. ${ }^{524}$ Section 306 is inapplicable where the

521. Pre-1954 law was unsettled as to redemptions from persons so closely related to the common stockholders as to "be equivalent to one economic unit." Marie W. F. NugentHead Trust, 17 T.C. 817 (1951), acq., 1952-1 Cuar. Bul. 3. See the Treasury's proposal (subsequently withdrawn) to amend Reg. 111, $\$ 29.115$ (g)-1(a) (2) (1943), P-H 1951 FEo. TAX SERv. I 76,019. See also Leopold Adler, 30 B.T.A. $\$ 97$ (1934), aff'd on ofincr groumds, 77 F.2d 733 (5th Cir. 1935); William Grimditch, 37 B.T.A. 402 (1938) (redemptions of stock acquired by gift or inheritance).

522. H.R. 8300 (House Bill) would have imposed upon the corporation a "transfer tax" of 85 percent of any amounts distributed in redemption of "non-participating" stod: within ten years from its issuance, with certain exceptions. Because the transfer tax did not apply to redemptions of either "participating stock" (as defined in $\S 312(\mathrm{~b})$ of the Bill) or "securities" (as defined in $\$ 312(a)$ ), the Bill would have permitted "bail outs" effected by redeemable non-voting common stock or securities subordinated to claims of trade creditors. And it would have been possible for the common stockholders to issue themselves preferred stock redeemable after ten years, hold it for eight or nine years, and then sell it to outsiders from whom it would be redeemed in the eleventh year. Also the transfer tax could apparent1y have been avoided by having the redemption qualify as a dividend to a purchaser of the preferred such as a tax-exempt charitable institution, an insurance company, or any corporation enjoying a low bracket for intercompany dividends. The overall effect of the House Bill would probably have been to encourage the "bail-outs" it purported to "eliminate" Sce H.R. REP. No. 1337, S3d Cong., 2d Sess. 36 (1954).

523. Stock dividends may now be received free of tax whether or not the distribution alters the recipient's proportionate interest in the corporation. INr. REv. Cone of 1954, \$305(a). See Sen. Rep. No. 1622, 83d Cong., 2d Sess. 44 (1954).

524. INT. REv. CODE of 1954, $\$ 306$ (a) (1) (A). The selling stockholders will not be entitled to the new dividend credit under id. $\$ 34$. However, the credit will be available under the corollary rule that if the preferred shares are subsequently redeemed by the corporation, the redemption proceeds will generally be treated as a dividend to the extent of corporate earnings at the time of the redemption. Id. \$306(a) (2). SEN. REP. No. 1622, 83d Cong., 2d Sess. 242 (1954). The statute anticipates and taxes a variety of possible schemes to avoid these rules. See, e.g., SEN. Rep. No. 1622, 83d Cong., 2d Sess. 242 (1954) (pledges of distributed stock); id. at 244-5 (exchange of distributed stock for common stock: of controlled corporation which is sold to outsiders); id. at 245 (issuance of low value stoel: with limited earnings assigned to it, followed by change in terms to render it more valuable). 
preferred shares are sold by the estate or legatee of the stockholder who received them as a stock dividend or in a reorganization, but this will be small consolation if the stock of a personal service corporation becomes unmarketable upon the death of one of its principal stockholders. ${ }^{525}$

\section{CoNCLUSION}

The many instances of capital gains taxation of the fruits of personal efforts are accidental by-products of unrelated technicalities in the tax law. No intention has been expressed by Congress or the courts to extend the capital gains tax to personal service income as such. Congress has merely approved some instances of this extension as "incentives" 520 and relief from "unduly harsh" taxation ${ }^{527}$ while condemning others as "loopholes." have repeatedly reached contradictory conclusions in parallel cases, ${ }^{, 20}$ largely because of economically insignificant technicalities used to define a "sale or exchange" of "property." Together Congress and the courts have produced a jumble of ad hoc solutions to specific problems, apparently giving little thought to the relation of personal service income to the general scope and purpose of the capital gains tax.

A possible explanation for the hodgepodge is that scope and purposes have dimmed with the passing years since the introduction of the capital gains tax in 1921. It is only necessary to contrast recent capital gains opinions with those of the 'twenties and 'thirties to document the proposition that much less weight is now given to considerations of policy. ${ }^{530}$ The few and cryptic official statements of capital gains philosophy and an unceasing and bewildering series of amendments to the statutory provisions ${ }^{531}$ may have macle the rationale of the capital gains tax so tenuous and uncertain that the courts-and perhaps Congressmen-can no longer use it as a guide.

If this were the full explanation for the law's many inconsistencies, the remedy would be a return to the original concept of the 1921 Act. In their age of innocence, capital gains were thought to be gains from capital investments such

525. Int. Rev. Code of 1954, $\S 306$ (c) (1) (C), 1014. See Sen. Rep. No. 1622, 83d Cong., $2 d$ Sess. 245 (1954). The absence of a $\$ 306$ tax would leave preferred with the advantage that it could be redeemed tax-free and with no loss of voting power by the estate to pay death taxes and administration expenses. INT. REv. CoDE of 1954, §303.

526. - SEN. REP. No. 2375, 81st Cong., 2d Sess. 59-60 (1950) (employee stock options).

527. Sen. Rep. No. 781, 82d Cong., 1st Sess. 50 (1951) (lump-sum payment in lieu of contingent deferred compensation).

528. SEN. REP. No. 2375, 81st Cong., 2d Sess. 43 (1950) (capital gains for amateur writers).

529. See, e.g., text at notes 104-110 and 129-34 (McFall and Corbyn), 182-7 and 188200 ( $O^{\prime}$ Rear and Wyler), 216-20 and 221-4 (Helvering v. Smith and Sreircn), 345-6 and 347-51 (Gwinner and Kuchman), 370-3, 371 (Laughton and Fox), 477-9 and 475-6 (Scofield and Carter) supra.

530. Compare Jones v. Corbyn, 186 F.2d 450, 452 (10th Cir. 1950), with Burnet v. Harmel, 287 U.S. 103, 106 (1932).

531. See Wells, Legislative History of Treatment of Capital Gains under the Fodcral Income Tax, 1913-1948, 2 NAT. TAX J. 12 (1949). 
as "farms, mineral properties, and other capital assets." would require repeal of the amendments permitting capital gains on personal effort, such as Section 165(b) ${ }^{533}$ and Section $130 A,{ }^{532}$ and the overruling of

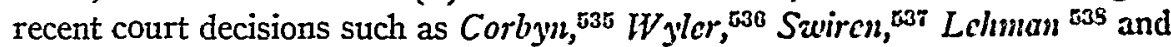
Herbert. ${ }^{539}$ However, even such a sweeping reversal would not solve the problem. It would affect only the most spectacular personal effort cases, and would not touch the capital gains treatment of sales of sole proprietorships, of partnership interests, and of stock in closely-held corporations, in all of which personal efforts are thoroughly intermixed with other elements, particularly the owners' financial investment. Capital gains have become clearly arailable to sales of partnerships and sole proprietorships only during the past deeade, but they have been obtained by owners of closely-held corporations ever since the 1921 Act. An attempt to restore the capital gains law to its lost purity would be abortive because the law was never really pure.

A more important objection to an attempted withdrawal of the capital gains tax from personal service income is the serious practical difficulty which would be encountered in isolating the personal effort element upon the sale of an interest in a business. ${ }^{540}$ Unless this problem can be solved satisfactorily, there is little point in prohibiting capital gains in the relatively unimportant situations where repealing a section or overruling a case could accomplish the prohibition. Capital gains would still be available in some personal service cases solely by reason of formal distinctions without economic differences.

The root of the problem is that the capital gains concept itself is clear and consistent neither in practice nor in principle. ${ }^{511}$ The anomalies encountered in personal effort situations are merely symptoms of this underlying confusion. Any attempt to bring about fair or consistent tax treatment of the fruits of personal effort is likely to be futile in the absence of a thoroughgoing reappraisal of the proper tax treatment of capital gains in a progressive income tax system.

532. See notes 24 and 48 supra.

533. Now $\$ 402$ (a) of the 1954 Code. See text at notes 13-17 supra.

534. Now $\$ 421$. of the 1954 Code. See text at notes $18-31$ and 313-18 sufra.

535. See text at notes 129-34 sipra.

536. See text at notes $188-200$ supra.

537. See text at notes 221-4 and 244-63 supra.

538. See text at notes 353-60 supra.

539. See text at notes $435-44$ supra.

540. See text at notes 181 and 378 supra.

541. See Miller, The 'Capital Asset' Concept: A Critigue of Capital Gains Taxation, Part II, 59 YaLE L.J. 1057 (1950). 


\section{THE YALE LAW JOURNAL}

\begin{tabular}{lll}
\hline Volume 64 & NOVEMBER, 1954 & NUMber 1 \\
\hline
\end{tabular}

EDITORIAL BOARD

Jerome A. Cohen

Editor-in-Chief

BARRY R. BRYAN

Article and

Book Reviezu Editor

Willians H. Dempsey, Jr. Gerald Walpin

Thomas F. Nelson Managing Editor

Gordon B. SpIvack

Note and Comment Editors

Irving J. Alter

Peter W. ANSON

ROBERT W. BEREND

Daniel M. Berger

Murry D. Brochin

Richard C. CAHN

Thomas N. Carruthers, Jr.

Donald J. CohN

JoH N W. Colleran

Alan P. Colodny

EDMund V. Conway

Gerald M. Doppeit

David A. Drexler

S. GoRDoN Elkins

JOSEPH M. FIETD

BARRY H. GARFINKEL
Charles S. Hatght, Jr. Stephien J. Pollak

ROBERT J. HARRIS

George C. Hastings

Ira Michael Heyman

Alexander P. HoFfManN

Charles D. Is aAC

David B. IsBell

LAWRENCE R. KLEIN

NoEl ARNold LeVIN

Charles S. Mechem, Jr.

Ralph C. Menapace, Jr.

Edward A. Miller

JON O. NEWMAN

LaWrence NewMan

MARTIN OPPENHEIMER

Otts P. Pearsall

Richard H. Pershan
Manvin N. RimM

Bernard S. Robins

Norbert A. Schler

Rayajond M. Shainderg

WAlter E. ShutTleworti

Jeanne Ritchie Silver

Monroe Silveruan

Rodert J. Sisk

ARLEN Specter

Melvin Stetn

JOHN T. SUBAK

Chinales H. Vejvoda

ROGER A. WELCII

HoWARD P. WILLENS

George C. ZnChanY

MARIE MCMAHoN

Business Secretary

\section{ROBERT H. JACKSON}

The Yale Law Journal mourns the death of Robert H. Jackson, Associate Justice of the United

States Supreme Court.

\section{CONTRIBUTOR TO THIS ISSUE}

Peter Miller. B.A. 1945, Columbia University; LL.B. 1948, Yale University. Member, New York Bar; Committee on Taxation of the Association of the Bar of the City of New York; Committee on Taxation and Law Reform of New York County Lawyers' Association. 